\title{
Prototype Air Cleaning System for a Firing Range
}
J. A. Glissmeyer
J. Mishima
J. A. Bamberger

January 1985

Prepared for the U.S. Army under a Related Services Agreement with the U.S. Department of Energy under Contract DE-AC06-76RLO 1830

Pacific Northwest Laboratory Operated for the U.S. Department of Energy by Battelle Memorial Institute 


\title{
DISCLAIMER
}

This report was prepared as an account of work sponsored by an agency of the United States Government. Neither the United States Government nor any agency thereof, nor any of their employees, makes any warranty, express or implied, or assumes any legal liability or responsibility for the accuracy, completeness, or usefulness of any information, apparatus, product, or process disclosed, or represents that its use would not infringe privately owned rights. Reference herein to any specific commercial product, process, or service by trade name, trademark, manufacturer, or otherwise, does not necessarily constitute or imply its endorsement, recommendation, or favoring by the United States Government or any agency thereof. The views and opinions of authors expressed herein do not necessarily state or reflect those of the United States Government or any agency thereof.

\author{
PACIFIC NORTHWEST LABORATORY \\ operated by \\ BATTELLE \\ for the \\ UNITED STATES DEPARTMENT OF ENERGY \\ under Contract DE-AC06-76RLO 1830
}

\begin{tabular}{|c|c|}
\hline \multicolumn{2}{|c|}{ Printed in the United States of America } \\
\hline \multicolumn{2}{|c|}{ Available from } \\
\hline \multirow{2}{*}{\multicolumn{2}{|c|}{$\begin{array}{l}\text { National Technical Information Service } \\
\text { United States Department of Commerce }\end{array}$}} \\
\hline & \\
\hline \multicolumn{2}{|c|}{ Springfield, Virginia 22161} \\
\hline \multirow{2}{*}{\multicolumn{2}{|c|}{$\begin{array}{l}\text { NTIS Price Codes } \\
\text { Microfiche A01 }\end{array}$}} \\
\hline & \\
\hline \multicolumn{2}{|c|}{ Printed Copy } \\
\hline & Price \\
\hline Pages & Codes \\
\hline 001-025 & $\mathrm{A} 02$ \\
\hline 026-050 & $\mathrm{A} 03$ \\
\hline 051-075 & A04 \\
\hline $076-100$ & A05 \\
\hline $101-125$ & A06 \\
\hline $126-150$ & $\mathrm{~A} 07$ \\
\hline $151-175$ & $A 0 B$ \\
\hline $176-200$ & A09 \\
\hline $201-225$ & $A 010$ \\
\hline $226-250$ & A011 \\
\hline $251-275$ & A012 \\
\hline $276-300$ & $A 013$ \\
\hline
\end{tabular}


PROTOTYPE AIR CLEANING SYSTEM FOR A FIRING RANGE

3. A. Gl issmeyer

3. Mishima

J. A. Bamberger

January 1985

Prepared for the U.S. Army under a Related Services Agreement with the U.S. Department of Energy under Contract OE-AC06-76RLO 1830

Pacific Northwest Laboratory Richland, Washington 99352 


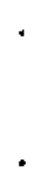




\section{EXECUTIVE SUMMARY}

This report recommends air cleaning system components for the U.S. Army Ballistics Research Laboratory's new large-caliber firing range, which is used for testing depleted uranium (DU) penetrators. The new air cleaning system must have lower operating costs during the life of the system compared to that anticipated for the existing air cleaning system. The existing system consists of three banks of filters in series; the first two banks are prefilters and the last are high-efficiency particulate air (HEPA) filters. The principal disadvantage of the existing filters is that they are not cleanable and reusable. The filters must be replaced frequently to maintain proper functioning of the ventilation system.

Pacific Northwest Laboratory focused the search for alternate air cleaning equipment on devices that do not employ liquids as part of the particle collection mechanism (e.g., liquids are used in many types of scrubbers). Collected dry particles were assumed preferable to a liquid waste stream. The dry particle collection devices identified included electrostatic precipitators; inertial separators using turning vanes or cyclones; and several devices employing a filter medium such as baghouses, cartridge houses, cleanable filters, and noncleanable filters similar to those in the existing system. The configurations and principles of operation of these devices are thoroughly described in the report.

The economics of practical air cleaning systems employing the dry particle collection devices were evaluated in 294 different combinations. The economic evaluation accounted for several factors including costs of equipment and its installation; labor, materials, and energy costs of operation and maintenance; costs of disposing of low-level radioactive wastes generated by operating the equipment; and the particle collection performance of the devices used in each system configuration considered. To evaluate how particle collection performance affects operating costs, a special method was devised and tested against operating data at other similar firing ranges. To assist the evaluation and to 
set performance criteria, data were obtained on the characteristics of the airborne particles to be collected and operating experiences at the other similar firing ranges.

The economic evaluation showed that systems employing no high-efficiency cleanable particle collection devices would have 20-year life cycle costs in the range of $\$ 5$ to $\$ 8$ million. In contrast, those systems employing a high efficiency cleanable device at the first particle collection stage, would have 20 -year life cycle costs in the range of $\$ 400$ to $\$ 800$ thousand. The recommended system configuration consists of a high-efficiency cartridge filter with automatic cleaning followed by the last two stages of disposable filters in the existing filter system. The HEPA filter bank is recomnended as the last stage to achieve the desired ultimate efficiency and to act as a final barrier to particle release. The high-efficiency prefilter would be retained upstream of the HEPA stage to collect the bulk of the particles penetrating the cartridge filter, especially if it should fail catastrophically because of excessive explosive overpressurization. Retaining this prefilter would extend the functional life of the HEPA stage. The existing filter housing should be relocated to make room for the cartridge house and used to house the two final filter banks and the existing fan. 
EXECUTIVE SUMMARY $\ldots \ldots \ldots \ldots \ldots \ldots \ldots \ldots \ldots \ldots \ldots \ldots \ldots \ldots \ldots \ldots \ldots \ldots \ldots \ldots \ldots \ldots$

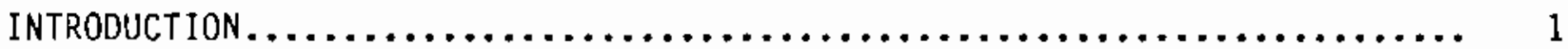

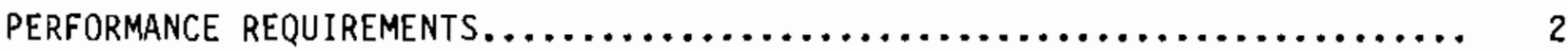

FLOW CAPACITY.................................... 2

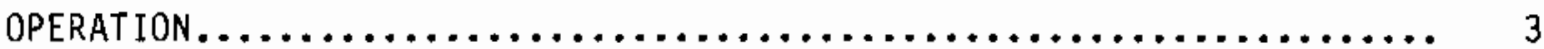

CONTAINMENT INTEGRITY............................... 4

AEROSOL CHARACTERISTICS............................ 5

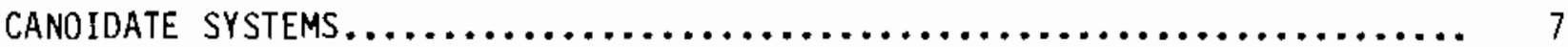

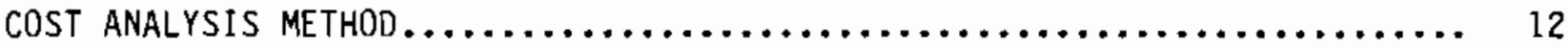

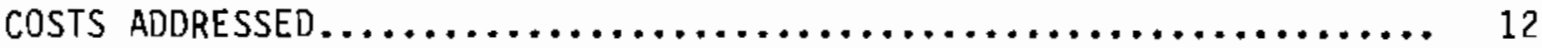

COST ASSUMPTIONS............................... 13

MEDIA LIFE.................................... 13

Disposable filters............................. 13

Cleanable Media................................... 15

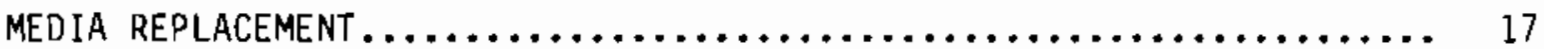

Cleanable Media and Peeled-Roll Filter.................... 17

Disposable and Rolling Filters....................... 18

Combined System................................ 18

MAINTENANCE. ................................... 18

Waste Disposal................................ 18

REPAIRS ........................................ 19

OPERATION....................................... 20

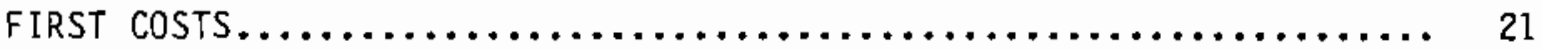


ELECTRICAL POWER $\ldots \ldots \ldots \ldots \ldots \ldots \ldots \ldots \ldots \ldots \ldots \ldots \ldots \ldots \ldots \ldots \ldots, 22$

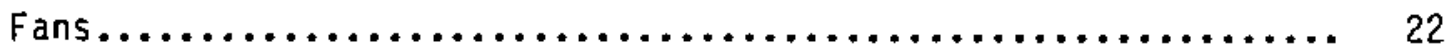

Continuous Equipment................................ 23

Intermittent Auxiliaries............................... 23

TOTAL COSTS........................................ 23

DISCUSSION............................................... 24

CONCLUSTONS............................................. 29

REFERENCES............................................ 30

APPENDIX A - MODELING FILTER EFFICIENCY........................ A.I

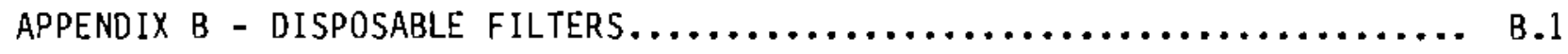

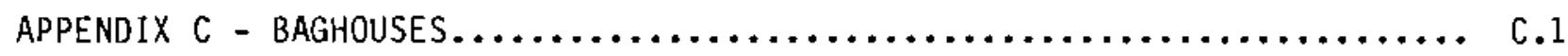

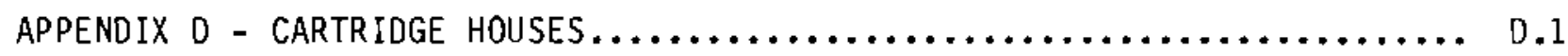

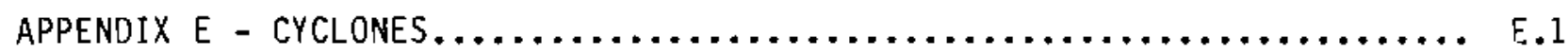

APPENDIX $F$ - EleCTROSTATIC PRECIPITATORS $\ldots \ldots \ldots \ldots \ldots \ldots \ldots \ldots \ldots \ldots \ldots$. F.

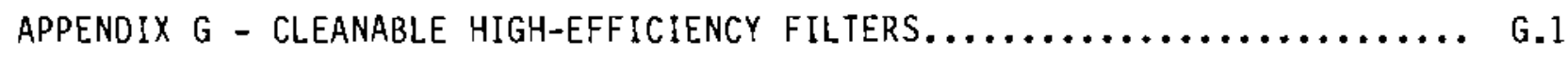

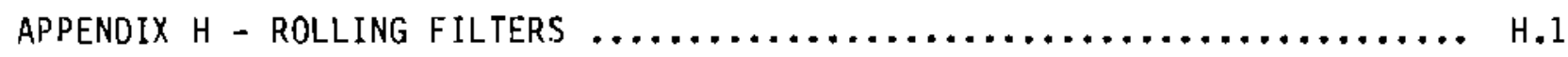

APPENDIX 1 - VANED INERTIAL SEPARATOR........................... 1

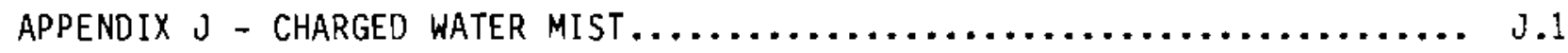

APPENDIX $K$ - INSTALLATION COST ESTIMATES........................ K.

APPENDIX L - COST ANALYSIS SUMMARY METHOD $\ldots \ldots \ldots \ldots \ldots \ldots \ldots \ldots \ldots \ldots \ldots \ldots \ldots \ldots \ldots$ 


\section{FIGURES}

1. Depleted Uranium Size Distribution........................... 6

2. Existing Filter House...................................... 9

3. Possible Orientation of Air Cleaning Equipment.................. 10

B.1 Typical Extended-Surface Filter $\ldots \ldots \ldots \ldots \ldots \ldots \ldots \ldots \ldots \ldots \ldots \ldots \ldots \ldots \ldots \ldots$, B.3

C.I Particle Collection on Woven and Felt Bag Media................. C.2

C.2 Pulse-Jet Baghouse Cross Section............................. C.4

C.3 High Pressure Pulse-Jet Baghouse........................... C.6

C.4 Cross Section of a Shaker Baghouse......................... C.8

C.5 Electrostatically Augmented Baghouse........................ c.9

D.1 Typical Cartridge House $\ldots \ldots \ldots \ldots \ldots \ldots \ldots \ldots \ldots \ldots \ldots \ldots \ldots \ldots, 0.2$

D.2 Walk-in Cartridge House $. \ldots \ldots \ldots \ldots \ldots \ldots \ldots \ldots \ldots \ldots \ldots \ldots \ldots \ldots \ldots \ldots, 0.3$

D.3 Horizontal Mount Cartridge House $, \ldots \ldots \ldots \ldots \ldots \ldots \ldots \ldots \ldots \ldots, 0.4$

E.1 Typical Cyclone Configuration.............................. E.2

F.1 Vendor K System Configuration............................ F.4

F.2 Vendor EE Tubular Electrostatic Precipitator................... F.6

F.3 Discharge Electrode Plates with Needles...................... F.7

G.1 Cleanable High-Efficiency Filter Showing Both Reverse Air
and Vacuum Cleaning System Configurations $\ldots \ldots \ldots \ldots \ldots \ldots \ldots \ldots . \ldots .2$

G.2 Pulsed Panel........................................ G.3

H.1 Peeled-Roll Filter Concept.............................. H.2

I.1 Vaned Inertial Separator Equipment Arrangement................. I.1

I.2 Vaned Inertial Separator................................ 1.2 


\section{TABLES}

1. Sumarized System Performance Criteria.................... 3

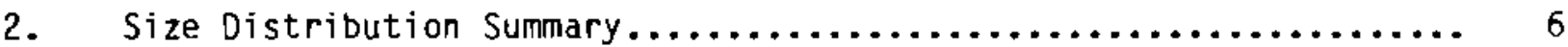

3. Candidate Air Cleaning Systems $\ldots \ldots \ldots \ldots \ldots \ldots \ldots \ldots \ldots \ldots \ldots \ldots \ldots$

4. Assumptions Used for Cost Estimating...................... 14

5. Particle Size Distributions--Percent Mass Per Size Bracket........ 15

6. Calculated Media Life............................... 16

7. Actual Filter Life Experience......................... 16

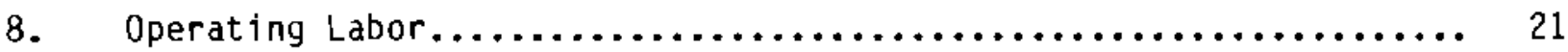

9. Cost Summary for Candidate Air Cleaning Systems................ 25

10. Advantages and Disadvantages For Remaining Candidate Systems...... 28

A.1 Efficiency and Cost Calculation for Size Distribution No. 3....... A.3

B.1 Fractional Efficiency and Loading Data for Existing Filters....... B.4

B.2 Cost of Replacing Banks of Disposable Filters $\ldots \ldots \ldots \ldots \ldots \ldots \ldots \ldots$ B.5

B.3 Disposable Filter Twenty-Year Maintenance................... B.5

Twenty-Year Total Costs by Filter Bank Combination for
Disposable Filters $\ldots \ldots \ldots \ldots \ldots \ldots \ldots \ldots \ldots \ldots \ldots \ldots \ldots \ldots \ldots \ldots \ldots \ldots \ldots \ldots \ldots \ldots \ldots \ldots$

C.1 Fractional Efficiency Data for Teflon-Coated Felt Bays........... C.10

C.2 Unit Flux by Particle Size.............................11

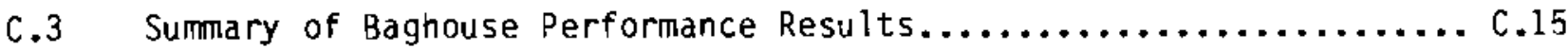

C.4 Shaker and Electrostatic Baghouse Filtering Efficiency.......... C.15

C.5a Descriptive Summary of Pulse-Jet Baghouses......................

C.5b Descriptive Summary of Shaker and Electrostatically

C.6a Pulse-Jet Baghouse First Costs, Excluding Fan............... C.18

C.6b Shaker and Electrostatically Augmented Baghouse First Costs, 
C.7 Installation Costs for Baghouses............................. 19

C.8a Twenty-Year Maintenance Costs for Pulse-Jet Baghouses........... C.20

C.8b Twenty-Year Maintenance Costs for Shaker and

Electrostatically Augmented Baghouses........................ C.22

C.9 Disposable Filter Usage for Pulse-Jet Baghouses............... C.24

C.10 Total Twenty-Year Cost for Pulse-Jet Baghouses................. C.26

C.11 Total Twenty-Year Cost for Shaker and Electrostatically

Augmented Baghouses....................................... c.28

D.1 Filter Efficiency for Cartridges........................... D.5

D.2 Descriptive Summary of Cartridge Houses..................... D.6

0.3 Cartridge House Acquisition Costs, Excluding Fan................ 0.6

D.4 Installation Costs of Cartridge House...................... D.7

D.5 Twenty-Year Maintenance and Compressor Power Costs.............. D.8

D.6 Estimated Usage Costs of Disposable Filters

Downstream from Cartridge Houses........................... D.9

0.7 Fan Requirements for Cartridge Houses....................... 0.9

D.8 Total Twenty-Year Cost of Cartridge Houses Using Standard

Media.................................................... 0.10

D.9 Total Twenty-Year Cost of Cartridge Houses Using Coated

Media................................................... D.10

E.1 Cycione System Specifications............................. E.3

E.2 Cyclone Costs......................................... E.4

E.3 Cyclone Fractional Collection Efficiencies................... E.5

E.4 Summary of Cyclone Characteristics......................... E.7

E.5 Twenty-Year System Maintenance............................. E.7

E.6 First Costs of Cyclones.................................. E.7

E.7 Erection Cost Estimates for Cyclones...................... E.8 
E.8 Twenty-Year Total Costs by Filter Combination.................. E.9

F.1 Comparison of the Electrostatic Precipitator Designs............. F.3

F.2 Electrostatic Precipitator Costs........................... F.9

F.3 Electrostatic Precipitator Collection Efficiency as a Function of Particle Size................................ F.1

F.4 Summary of Electrostatic Precipitator Characteristics.............F.12

F.5 Summary of Electrostatic Precipitator First Costs................ F.13

F.6 Erection Costs for Electrostatic Precipitators.................. F.13

F.7 Electrostatic Precipitator Maintenance Estimates................. F.14

F.8 Twenty-Year Total Costs by Filter Bank Combination for Precipitators.......................................... F.15

G.1 Performance Input Data for Cleanable High-Efficiency Filters....... G.3

G.2 Summary of Characteristics of Cleanable High-Efficiency Filters............................................... G.4

G.3 Installation Costs for Cleanable High-Efficiency Filters.......... G.5

G.4 First Costs of Cleanable High-Efficiency Filters,

Excluding Fan....................................... G.5

G.5 Maintenance Costs for Cleanable High-Efficiency Filters........... G.7

G.6 Twenty-Year Total Costs by Filter Bank Combination for

Cleanable High-Efficiency Filters.......................... G.8

H.l Rolling Filter Media Replacement Cost...................... H.2

H.2 Rolling Filter Efficiency Data............................. H.3

H.3 Characteristics of Rolling Filters.......................... H.4

H.4 Rolling Filter Initial Costs............................. H.4

H.5 Peeled-Roll Filter Installation Costs........................ H.4

H.6 Maintenance Costs for Rolling Filter....................... H.5

H.7 Peeled-Roll Filter Fractional Efficiency...................... H.6

H.8 Twenty-Year Cost of Rolling Filter......................... H.8 
I.1 Fractional Filter Efficiency Data for Vaned

Inertial Separator..................................... I.3

1.2 Calculation of Combined Vaned Inertial Separator

and Pulsed-Panel Efficiency.............................. I.4

I.3 Vaned Inertial Separator Descriptive Summary................ I.6

I.4 Vaned Inertial Separator Initial Costs, Excluding Fan.......... I.6

I.5 Vaned Inertial Separator Twenty-Year Maintenance............. I.6

I.6 Twenty-Year Total Costs by Filter Bank Combination for Vaned Inertial Separator and Pulsed-Panel System............... I.6

K.1 Cost Estimate Summary for Installation, Fans, and

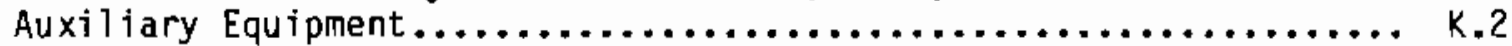

L.1 Breakdown of Disposable Filter Usage Costs.................. L.2

L.2 Breakdown of Initial Investment and Maintenance Costs.........

L.3 Breakdown of Power, Replacement Media, and Waste

Disposal Costs....................................... L.5 



\section{INTRODUCTION}

The Ballistics Research Laboratory (BRL), a component of the U.S. Army Research and Development Command (ARDC), has contracted with Pacific Northwest Laboratory (PNL) to supply a prototype air cleaning system for a new indoor large-caliber range where depleted uranium (DU) munitions are tested. Pacific Northwest Laboratory's objective was to modify or replace the existing air cleaning system to reduce operating and waste management costs without losing particulate containment capability. Another desired benefit was to reduce the aerosol clearance time in the target building from that experienced at BRL's older range.

This final report of the feasibility study phase details the methodology and rationale behind the recommendation of an air cleaning system. This report was preceded by reports on the performance of air cleaning systems at existing ranges (Bamberger $1983 a^{(a)}$ ), the characteristics of the effluent particles (Mishima 1983a, $b^{(b)}$; Bamberger $1983 b^{(c)}$ ) and the performance criteria for the prototype system (Glissmeyer $1984^{(d)}$ ). In this report the performance criteria and the candidate emission control systems are briefly summarized. The factors addressed in the cost analysis are detailed and the cost estimates for the candidate systems are discussed. The cost analysis for each candidate system and the method used to calculate the filtration performance of combined devices are detailed in the Appendices. The advantages and disadvantages of each system are discussed and air cleaning system recommendations are made.

(a) Bamberger, J. A. 1983a. Task 2 Report: Performance of Existing Air Cleaning Systems, Informal Report to U.S. Army Ballistics Research Laboratory, prepared by Pacific Northwest Laboratory, Richland, Washington.

(b) Mishima, J. 1983a. Task 3 Report: Effluent Characterization. Informal Report to U.S. Army Ballistics Research Laboratory, prepared by Pacific Northwest Laboratory, Richland, Washington.

Mishima, J. 1983b. Addendum to Task 3 Report. Informal Report to U.S. Army Ballistics Research Laboratory, prepared by Pacific Northwest Laboratory, Richland, Washington.

(c) Bamberger, J. A. 1983b. Particle Size and Concentration vs Time Data, Informal Report to U.S. Armit Ballistics Research Laboratory, prepared by Pacific Northwest Laboratory, Richland, Washington.

(d) Glissmeyer, J. A. 1984. Development of a Prototype Air Cleaning System for a New Target Building, Task 4: Prototype System Criteria. Informal Report to U.S. Army Ballistics Research Laboratory, prepared by Pacific Northwest Laboratory, Richland, Washington. 


\section{PERFORMANCE REQUIREMENTS}

The minimum performance requirements for the air cleaning system (ACS) were developed in the Prototype System Criteria (PSC) report. (a) The requirements addressed included airflow rate, filtering efficiency, and structural characteristics. Table 1 summarizes the conclusions of that report.

\section{FLOW CAPACITY}

The design air flow, 24,000 actual cubic feet per minute (acfm) and the present internal volume of the firing range should result in a clearance time of around $60 \mathrm{~min}$ to an acceptable concentration level for DU particles of $0.02 \mathrm{mg} / \mathrm{m}^{3}$. This clearance time is on the border of acceptability for range operation and is the result of incoming clean air being mixed poorly with the volume inside the target bay. The clearance time for the target bay, given perfect mixing, would be about $24 \mathrm{~min}$. Ballistics Research Laboratory suggested doubling the airflow to shorten the clearance time; however, this would double the cost of the ACS and require structural modifications to avoid a large pressure loss through the ventilation system. By partly opening up the front of the target-fragment shield or extending the ventilation exhaust intakes toward the fragment shield, the mixing could be substantially improved. This was discussed extensively in the PSC report, and the recommendation was made to continue to use the original flow rate in this study.

The existing fan has inadequate pressure capacity [11 in. water gauge (WG) at 24,000 acfm] to maintain the design airflow, because the sum of the pressure drops across the structure and fully loaded filter banks is estimated as 15 in. WG. In the PSC we recommended that bellmouths be added at ventilation intakes and the 2-ft orifices be removed from the shock attenuators. These modifications would reduce the required fan pressure capacity to around $11 \mathrm{in.} W G$. When selecting new ACS components, the effects of system pressure drops on the cost analysis were considered.

(a) Glissmeyer, J.A. 1984. Development of a Prototype Air Cleaning System for a New Target Building, Task 4: Prototype System Criteria. InformaT Report to U.S. Army Ballistics Research, prepared by Pacific Northwest Laboratory, Richland, Washington. 
TABLE 1. Summarized System Performance Criteria

1. Flow Capacity $24,000 \mathrm{acfm}(680 \mathrm{acmm})$ constant

2. Operation Continuous during $8 \mathrm{~h} /$ day

ambient temperature, humidity

3. Dust Characteristics

a. $4.9 \mathrm{~kg}$ per shot

b. 300 shots/yr, maximum of 4 shots in any day

c. Size distribution: see text and Table 2

d. Composition: $20 \mathrm{wt}^{\%} \mathrm{UO}_{2}$

$70 w t \% U_{3} 0_{8}$

$9 \mathrm{wt} \% \mathrm{Fe}_{\mathrm{x}}$

$1 \mathrm{wt} \% \mathrm{SiO}_{x}, \mathrm{AlO}_{x}, \mathrm{TiO}_{x}, \mathrm{H}_{2} \mathrm{O}, \mathrm{HNO}_{3}, \mathrm{KOH}, \mathrm{H}_{2} \mathrm{SO}_{4}$

4. Peak Pressure Pulse 3 psi for 0.5 to $1.5 \mathrm{~s}$

5. Minimum System Filtering Efficiency $99.998 \%$ at $0.5 \mathrm{~g} / \mathrm{m}^{3}$ inlet concentration

6. Minimum New Prefiltration Efficiency at $0.5 \mathrm{~g} / \mathrm{m}^{3}$ inlet concentration, finest aerosol

$99 \%$ if bank 2 replaced

$91 \%$ if bank 2 retained

7. Maximum Clearance Time $60 \mathrm{~min}$ to $0.02 \mathrm{mg} / \mathrm{m}^{3}$ interior concentration

\section{OPERATION}

Because the range will be operated under all weather conditions and because the make-up air is not heated or otherwise conditioned, the air in the ventilation system will be at ambient temperature and humidity. Therefore, there is little need for the ACS to be insulated or heated in most cases. However, condensation may possibly occur at high humidity and pressure drop through the system. If condensation occurs during test firings, the condensate may be somewhat corrosive because acidic and basic fumes are present from the 
burning propellant (see Table 1). Hence, corrosion resistant materials or finishes may be required on the ACS interior. Also, because the ACS is currently outdoors on a concrete pad near the shore of Chesapeake Bay, the new equipment should be appropriately weatherproofed.

Because liquid radioactive wastes cannot be processed on site, only devices for dry collection of particles are considered to be applicable. Particles will be retained on the media or transferred to disposal containers. If collected particles are temporarily stored in hoppers, the hoppers should be designed to minimize reentrainment of the particles into the ventilation air. Appropriate operating procedures must be instituted to minimize worker exposure to the waste DU particles in the containers.

The preferred candidate ACS should be designed so that the collection media can be inspected and changed out on the clean side (downstream side) of the system and out of the weather. Used media should be easy to remove and contain so that the external and inhalation exposure to personnel are minimized. If media access is external to the device, the entire ACS may need to be enclosed to facilitate all-weather maintenance.

\section{CONTAINMENT INTEGRITY}

Al1 components of the ACS must be designed to withstand both the maximum vacuum that the fans can exert and the pressure pulses generated by the est $i-$ mated 6000 test firings that will occur during the 20 -year life of the equipment. The peak pressure pulse is estimated to be 3.0 psig with a duration of $1.5 \mathrm{~s}$, at the inlet of the ACS. The maximum vacuum pressure requirement of any of the proposed ACSs is $27.2 \mathrm{in}$. WG if the recommended structural modifications mentioned earlier are implemented -- otherwise, the maximum pressure is 31 in. WG. These pressure extremes ( +3 psig, $-31 \mathrm{in}$. WG or about -1 psig) must not disrupt the collection media or the air-tight seals at critical locations in the ACS (e.g., access doors, media, ductwork joints, or other seals that could allow leakage to the atmosphere or bypassing the particle removal stages). The ACS eventually chosen, or additions thereto, will be required to pass a leak test on site. We recommend that the vended system be pressurized to 3 psig and 
the measured leak rate not exceed a set criterion. The leak criterion and the test method are outlined in ANSI/ASME (1980a) standard N509-1980 and ANSI/ASME. (1980b) standard N510-1980.

If new filter banks are required, a 2-ft separation and a screen should be placed between each bank to prevent media from a failed filter from damaging or plugging downstream filters. The critical filter seals should be on the downstrean side so the pressure wave will not work against the seal. A working space should also be constructed between the banks to permit close inspection of filter seals.

The structure will be rocated outdoors and will need to withstand wind and snow loads experienced in the area. The exterior finish should protect the structure against corrosion induced by the elements. The air cleaner will mate with the existing shock attenuators and possibly the filter house. Access must be provided for interior cleaning and inspection of wear and corrosion.

AEROSOL CHARACTERISTICS

The composition of the aerosol generated during test firings was summarized in Table 1. Three particle size distributions were considered for use in evaluating ACS performance. These size distributions were measured during test firings using cascade impactors, which quantify uranium mass as a function of aerodynamic particle size. The measurements are expressed as log-normal distributions with the parameters listed in Table 2.

Figure 1 shows these size distributions as log-normal probability plots. Measurements 1 and 3 were made adjacent to the targets during outdoor tests (G1issmeyer and Mishima 1979), and Measurement 2 (Chambers et al. 1982) was made adjacent to targets inside a target bay at BRL's enclosed range (see the PSC report for a detailed discussion). None of these measurements were made under conditions that exactly simulated those expected at the ACS; therefore, we cannot predict the actual size distribution of the aerosol challenging the ACS. Because the filtering efficiencies tend to be lower for smaller particles, we chose to use the finest size distribution (Measurement 3, Table 2) for assessing the performance of candidate ACSs. Using the finest size 
TABLE 2. Size Distribution Summary

$\begin{array}{ccc}\text { Measurement } & \begin{array}{c}\text { Mass Mean } \\ \text { Aerodynamic Particle } \\ \text { Diameter, } \mu \mathrm{m}\end{array} & \begin{array}{c}\text { Geometric } \\ \text { Standard } \\ \text { Deviation }\end{array} \\ 1 & 2.7 & \frac{6.3}{2.7} \\ 2 & 1.6 & 13.0 \\ 3 & 0.81 & 22.9\end{array}$

distribution may result in underestimating filtration performance and overestimating the cost of operating the system. However, this method will be applied uniformly to all devices to avoid giving unfair advantage to any system and to preserve the relative cost ranking of each candidate.

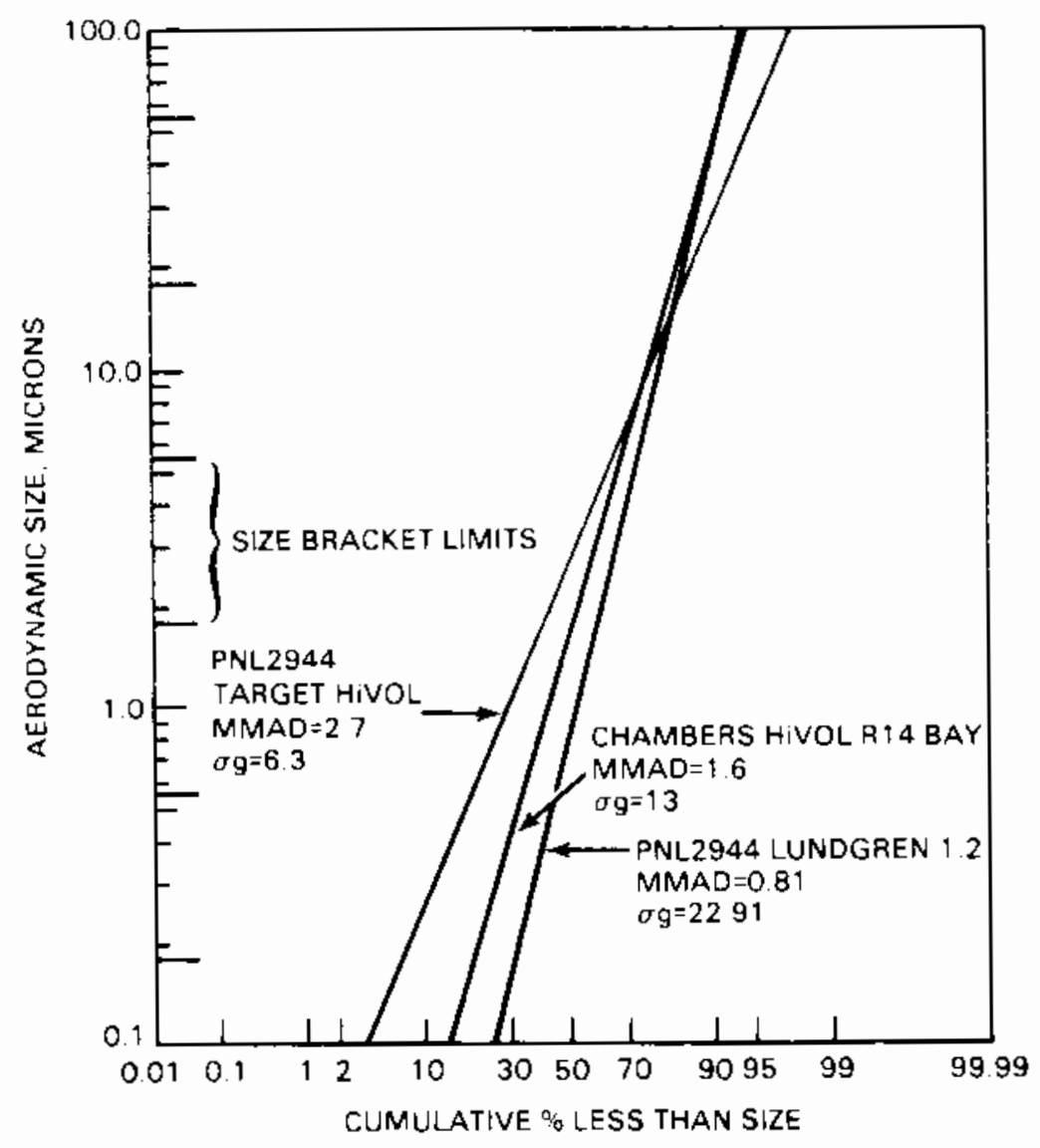

FIGURE 1. Depleted Uranium Size Distribution 


\section{CANDIDATE SYSTEMS}

The basic assumptions for selecting equipment were that 1) particle collection should not produce a liquid effluent requiring treatment, and 2) the final control device will be a bank of high-efficiency particulate air (HEPA) filters to act as a final polishing and safety stage. Therefore, the candidate ACSs consist of a primary device for dry particle collection followed by one or more banks of disposable filters, the last bank being HEPA filters. These systems are described only briefly here; thorough descriptions and illustrations can be found in the appendices. The fifteen candidate types are listed in Table 3.

\section{TABLE 3. Candidate Air Cleaning Systems}

1. Existing Disposable Filters

2. Existing Disposable Filters With Extended Surface Filter in Place of Bank 2

3. Rolling Prefilter + Disposable Filters

4. Peeled-Roll Filter + Disposable Filters

5. Pulse-Jet Baghouse + Disposable Filters with standard felt media or with coated media

6. Shaker Baghouse + Disposable Filters with standard fabric media or with coated felt media

7. Electrostatically Augmented Baghouse + Disposable Filters

8. Cartridge House + Disposable Filters with standard media or with coated media

9. Cyclones + Disposable Filters

10. Electrostatic Precipitator + Disposable Filters

11. Vaned Inertial Separator + Pulsed Panel Filter + Disposable Filters

12. Cleanable High-Efficiency Filter + Disposable Filters 
The existing filters are the disposable type consisting of three banks of 24 filters each. The first bank has 2 -in.-deep pleated filters rated $25 \%$ efficient by ASHRAE 52-76 (1976) dust spot test, the second bank has 11.5-in.-deep pleated filters rated $95 \%$ efficient by ASHRAE $52-76$ dust spot test, and the third has 11.5-in.-deep pleated HEPA filters. Each filter is $2 \mathrm{ft}$ high and $2 \mathrm{ft}$ wide, and the banks are three filters high and eight filters wide. The filter frames are made of sheet metal and, together with the fan, are housed in a 12-gauge galvanized steel building on a 22-ft-square pad. Figure 2 shows the layout of the filter house.

We assumed that for most of the candidate systems the existing filter house will be used and one or more of the filter banks will be employed downstream of the primary device; however, the fan may be of greater static pressure capacity and relocated outside the housing. The primary device will probably displace the filter housing and fan to an adjacent pad as illustrated in Figure 3.

In baghouses, particles are collected on the surface of a tubular or flat fabric bag. The bag is periodically cleaned by shaking or by pulsing compressed air through the bag. Seventeen vendors provided cost information for baghouses, mostly for those cleaned with compressed air (pulse-jet). The cartridge house is functionally identical to, but more compact than, the pulse-jet baghouse. Instead of collecting particles on fabric bags, they are collected on a cellulose mat that is pleated and formed into a cartridge similar to the carburetor air-cleaners of trucks.

The electrostatic precipitator (ESP) charges aerosols by corona discharge at electrodes. The charged particles then migrate to oppositely charged plates. Particles built-up on the collection plates are removed by agitating the plates with rappers or acoustically induced vibration. The particles then fall into a hopper for transfer to containers. Four vendors provided information on eight ESPS suitable for this study.

In a cyclone, the airflow is caused to move in a tornadic fashion. Large particles move to the outer wall by centrifugal force and are moved downward to a hopper by gravity. Three vendors provided information on cyclanes for this study. 


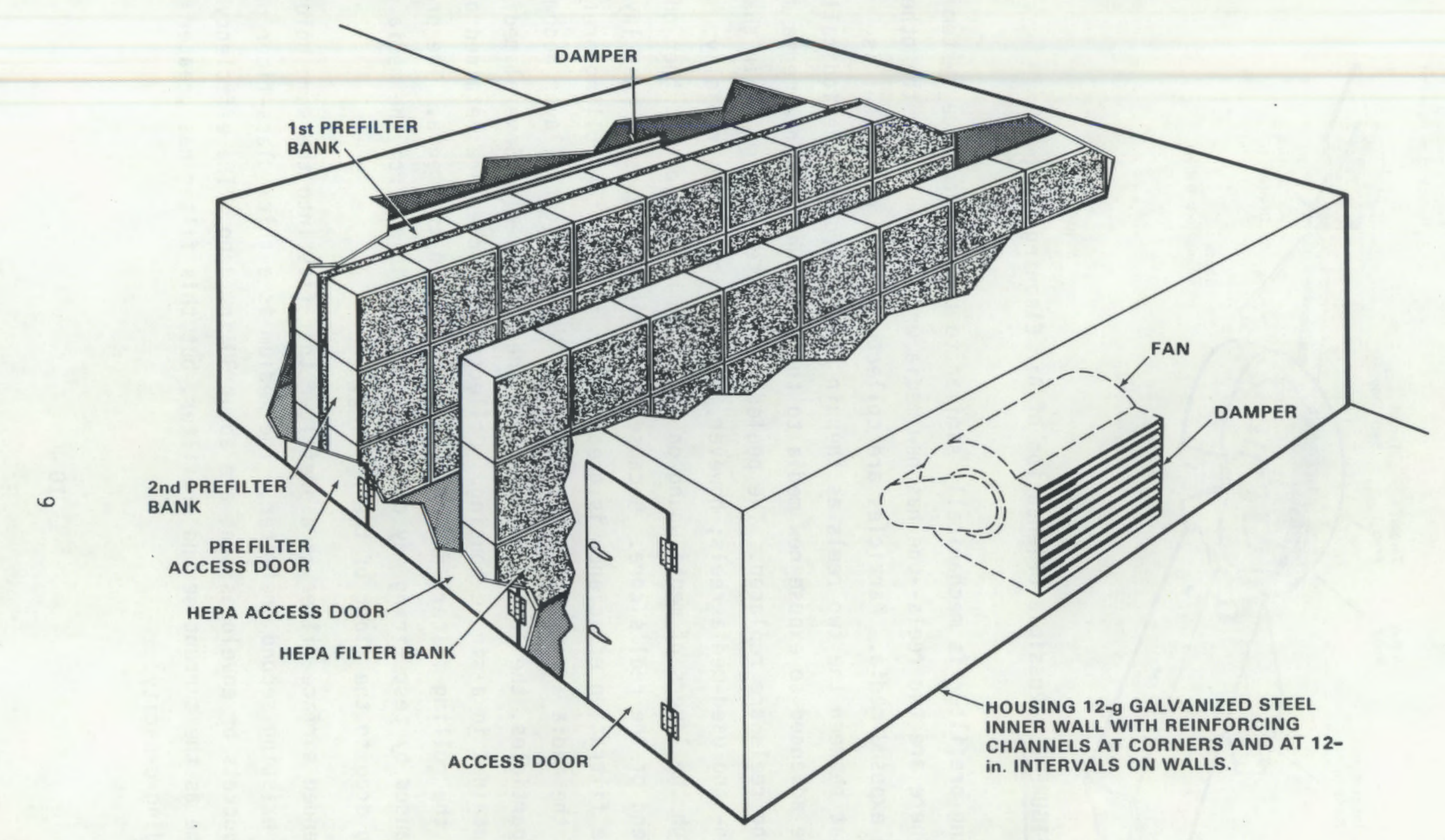

FIGURE 2. Existing Filter House 


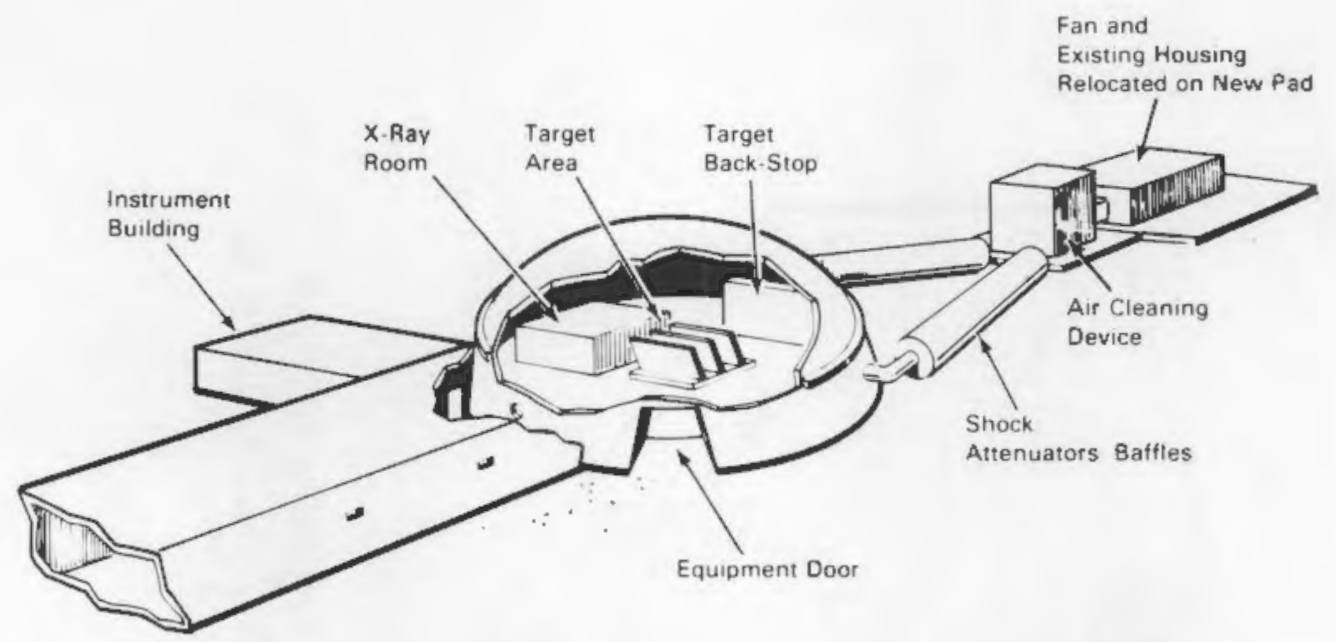

FIGURE 3. Possible Orientation of Air Cleaning Equipment

A rolling prefilter is mechanically similar to the film advance system in a camera. There are two reels--one has new media wrapped on it and the other takes up the exposed media. Particles are collected on the media that is stretched flat between the two reels as the air passes through. Periodically, the reels are advanced to expose new media to the air. When the new media are exhausted, the reels are replaced. The peeled roll filter is similar in that it uses clean- and used-media reels; however, the airflow passes radially inward through the layers of media wound on the clean media reel and then out through the end of the reel's core. Because the air passes through many layers of media, the filtration efficiency is greater than that of the rolling prefilter although the media are essentially the same. When the outer layer becomes loaded with particles, the layer is wound onto the other reel. Several media units are contained in a single housing. Collected particles are retained on the media of the rolling filters and are disposed of with the media. The pressure waves caused by test firing may dislodge some particles from the media and cause them to drop to the floor of the housing.

The extended surface filter is a prefilter that fits into the same holding frame as the existing second prefilter. The medium is a thick glass-fiber pad shaped into pockets or envelopes that are about $30 \mathrm{in}$. deep. The efficiency is about the same as the current second prefilter, but this filter has greater particle-holding capacity. 
The cleanable high-efficiency filter contains one or two banks of highefficiency filters that look similar to the HEPA filter used in the existing system. The filters differ from the MEPAs in that they have a thin coating on the particle collection side so particles cannot penetrate into the fibers of the media. The medium acts as a support for the porous coating, which does the filtering. The filters are cleaned in place using either a vacuum system or pulses of compressed air. Two vendors were found that supply this type of equipment.

In the pulsed panel device, the cleanable filter panels are housed in a steel box with hoppers beneath. The filter medium is very similar to the medium-efficiency prefilter in bank 2 of the existing system except the media are not pleated as deeply and the individual filter dimensions are $2 \mathrm{ft} x$ $4 \mathrm{ft} \times 3 \mathrm{in}$. For the design airflow, the pulsed panel device would contain 24 panel filters. The filters are cleaned periodically with pulses of compressed air flowing in the direction opposite to the airflow.

The vaned inertial separator is rated at about $80 \%$ efficiency under ASHRAE 52-76 (1976). Ninety percent of the airflow is sharply turned through vanes, while $10 \%$ of the airflow proceeds in a straight line. Large particles cannot follow the rapid change in direction and follow the $10 \%$ airflow in a straight line. The 10\% airflow, now more heavily laden with particles, is passed through a pulsed panel unit that will remove $80 \%$ to $90 \%$ of the particles. The airflows from the vaned inertial separator and the pulsed panel are recombined and passed through a second pulsed panel with a 24,000 acfin capacity. Two vendors were found to manufacture the vaned inertial separators.

Each combination of primary device and disposable filters was considered as a candidate ACS. Usually, four estimates were generated for the cost and performance of each ACS. Each estimate was for a different combination of disposable filters to be used downstream. The four combinations were banks 1 , 2 , and 3 ; banks 2 and 3 ; bank 3 ; and banks 1 and 3 . Different vendors were contacted to obtain cost estimates for equipment they recommended. From the information gathered, different cost and performance estimates for candidate ACSs were made following the methods discussed in the next section. 


\section{COST ANALYSIS METHOD}

Because this application of an air cleaning system is unique and applicable data on the performance of the filters are lacking, it must be realized that costs attributed to the different ACS configurations are estinates based on several imponderables. Such factors considered in this study were the particle collection efficiency of devices, individually or in series, and the frequency of mechanical repairs. The former proved to be the most significant because several important items hinge on the question of efficiency. Inciuded in this category are the life of media, frequency of media replacenent, media disposal, and the disposal of collected dust. We have used the best efficiency data avajlable to us from the literature or vendors; however, in most cases, extrapolations beyond the data were required and are noted where they appear. Estimates of maintenance and repairs were obtained largely from vendors. Estimating methods were applied uniformly to identify the relative ranking of the candidate ACSs, even though the estimates were inexact overall. In most cases the ACSs include all or a part of the existing filter banks as after- or polishing-filters. To explore which filter banks should be retained, cost estimates were generated for each practical combination of the existing afterfilters with candidate devices.

\section{COSTS ADORESSED}

A complete estimate of procurement, operating, and maintenance costs of each ACS was attempted. The cost elements addressed were

- media life

- media replacement

- waste disposal

- first costs

- maintenance

- electrical power
-- how long the media lasts

-- replacement and disposal of media

-- disposal of collected powder

-- initial investment in equipment and installation

-- operation, maintenance, and repairs of ACS

-- power requirements of fan and auxiliaries.

The general method of estimating these elements will be explained in the following subsections. Labor costs are assessed under the topics to which the labor is applied. 
COST ASSUMPTIONS

The several assumptions that we used as a starting point for cost estimating are enumerated in Table 4. We also assumed that HEPA filters will be retained as the last device in an ACS for a polishing and safety stage. These assumptions are used several times in the estimating method. Other assumptions are introduced as they pertain to specific method elements.

\section{MEDIA LIFE}

The life expectancy of the media is a concern in all of the devices except cyclones or ESPS. Mechanical media failure resulting in particle leakage is the principal factor determining the life of cleanable media. The filtration efficiency of cleanable media affects only the subsequent disposable filters, because it determines the challenge aerosol. For disposable filters, the filtering efficiency and the particle-holding capacity are equally important to media life. Therefore, the question of media life is approached differently for the two media types.

Disposable Filters

The approach developed was applied to all of the types of disposable filters investigated: the rolling filters, existing filters, and extendedsurface filters. To estimate media life, both the filtration efficiency as a function of aerodynamic particle size and the dust holding capacity at the final operating pressure drop must be known; however, data covering the entire range of interest were generally not available and extrapolations were required. The data on efficiency and dust capacity for the individual devices are discussed in Appendices $B$ through $\mathrm{J}$.

The particle size range of interest was subdivided into seven size brackets, equally spaced logarithmically. The mass of particles in each bracket was estimated from the size distribution plots (Figure 1) as shown in Table 5. All of the particles in a given bracket were assumed to behave as particles the size of the bracket midpoint. The collection efficiency of each device was obtained for each size bracket midpoint. The amount of particles collected by and penetrating a device was computed for each size bracket. The 
TABLE 4. Assumptions Used for Cost Estimating

\begin{tabular}{|c|c|}
\hline Variables & Assumed Values \\
\hline Labor rate for BRL personnel & $\$ 31 /$ man-hr \\
\hline Power cost & $\$ 0.04 / \mathrm{kWh}$ \\
\hline $\begin{array}{l}\text { Waste disposal cost including } \\
\text { container, shipping fees, } \\
\text { labor, burial fees }\end{array}$ & $\$ 25 / \mathrm{ft}^{3}$ \\
\hline ACS equipment life & 20 year \\
\hline $\begin{array}{l}\text { Test firings that ACS will } \\
\text { be exposed to }\end{array}$ & 6000 \\
\hline Average weight of test round & $4.9 \mathrm{~kg}$ \\
\hline Average aerosol mass per test & $4.9 \mathrm{~kg}$ \\
\hline $\begin{array}{l}\text { Bulk density of the collected } \\
\text { dust }\end{array}$ & $1.5 \mathrm{~g} / \mathrm{cm}^{3}$ \\
\hline $\begin{array}{l}\text { Annual operating time for ACS } \\
(365 \text { day } \times 5 / 7-10 \text { holiday }) \times \\
8 \mathrm{hr} / \text { day }=\end{array}$ & $2006 \mathrm{hr}$ \\
\hline
\end{tabular}

total amounts collected and penetrated were computed by summing the bracket values. To estimate the fraction of filter life (life fraction, LF) used by a test shot, the vendor's estimated particle-holding capacity was divided into the mass of particles collected during a test firing. The inverse of this value is the average estimated number of shots to which the device could be exposed before replacement. The penetrated particle mass distribution per size bracket was used as the input derosol to the next stage of filtration. This approach was used to estimate the useful life of a disposable filter as an individual unit or as a bank of units in series.

An example of the application of this method is shown in Appendix A. The dust holding capacities, filter collection efficiencies, and calculations using this method are detailed in the appropriate appendices covering each candidate 
TABLE 5. Particle Size Distributions--Percent Mass Per Size Bracket

\begin{tabular}{|c|c|c|c|c|}
\hline & Bracket Midpoint & Mass & istrib & $n, \%$ \\
\hline Bracket & Size, $\mu m$ & No. 1 & No. 2 & No. 3 \\
\hline 1 & 0.1 & 7.3 & 20 & 31 \\
\hline 2 & 0.32 & 12.7 & 14 & 14 \\
\hline 3 & 1.0 & 20.5 & 18 & 15 \\
\hline 4 & 3.2 & 25.5 & 17 & 13 \\
\hline 5 & 10.0 & 19.0 & 14 & 11 \\
\hline 6 & 32.0 & 10.3 & 9 & 7 \\
\hline 7 & 100.0 & 4.7 & 8 & 9 \\
\hline
\end{tabular}

ACS. This method was first tested on the existing filters and resulted in the filter replacement frequencies shown at the bottom of Table 6 . Table 7 shows the disposable filter life experienced at existing ranges. Comparing the values for disposable filter life shows that the estimates calculated using this method were within the range experienced at other ranges, giving us some confidence in the method. As stated in the performance requirements, the finest size distribution (Table 5, No. 3) was used in this study to estimate media life and particle penetration.

Cleanable Media

Estimates of media life for the cleanable media devices were obtained from the equipment manufacturers, who usually do not make the media they supply except for the cleanable high-efficiency filters. The estimates from the manufacturers are based on extensive experience with their users. The controlling factor for these devices is mechanical wear resulting in filter media failure. Most often these devices are used in harsh industrial ventilation environments where aerosol concentrations are higher and more continuous than expected for the firing range. Most vendors felt that the aerosol loading at the firing range is light compared to their typical applications. The life estimates for each device using cleanable media are detailed in the appropriate appendices and are summarized in Table 6 . 
IABLE 6. Calculated Media Life

\begin{tabular}{|c|c|}
\hline Device & $\begin{array}{c}\text { Life Expectancy, } \\
\text { months }\end{array}$ \\
\hline $\begin{array}{l}\text { Common Rolling Filter } \\
\text { Peeled-Roll Filter } \\
\text { Pulse-Jet Baghouse: Standard Felt } \\
\text { Coated Felt } \\
\text { Electrostatically Augmented Baghouse } \\
\text { Cartridge House } \\
\text { Cleanable High-Efficiency Filter } \\
\text { Pulsed Panels } \\
\text { Shaker Baghouse }\end{array}$ & $\begin{array}{c}1 \\
84 \\
24 \\
27 \\
24 \\
24 \\
80-120 \\
1 \\
60\end{array}$ \\
\hline & No. Shots \\
\hline $25 \%$ ASHRAE Prefilter & 4 \\
\hline 95\% ASHRAE Prefilters & 4 \\
\hline HEPA Filters & 31 \\
\hline 95\% ASHRAE Extended Surface Filter & 8 \\
\hline
\end{tabular}

TABLE 7. Actual Filter Life Experience

\begin{tabular}{|c|c|c|c|c|}
\hline \multirow[b]{2}{*}{ Range } & \multirow{2}{*}{$\begin{array}{l}\text { Shots } \\
\text { Per Year } \\
\end{array}$} & \multicolumn{3}{|c|}{$\begin{array}{c}\text { Range of Filter Life, } \\
\text { Rounds/Change }\end{array}$} \\
\hline & & 1st Prefilters & 2nd Prefitters & HEPAS \\
\hline $\begin{array}{r}\text { Other } \\
\text { Site }\end{array}$ & 230 & $1-2$ & $10-20$ & $100-200$ \\
\hline BRL & 180 & $1-6$ & $1-6$ & $5-60$ \\
\hline
\end{tabular}

To estimate the characteristics of the challenge aerosol that is passed to units downstream and the quantities of dust to be transferred to disposal containers, the calculation method described above for the disposable filters was also applied to most cleanable media devices. For pulse-jet baghouses an alternate method based on current research was used for estimating the downstream aerosol size distribution. The alternate method, detailed in Appendix $C$, discards the notion of collection efficiency and relates penetration flux to the media area, dust cake on the media, and the frequency of cleaning. 
MEDIA REPLACEMENT

To estimate the cost of replacing filter media, several factors were taken into account:

- the cost of new media

- the cost of disposing of used media

- the labor to change the media

- the volume of the compacted media

- the labor to compact the used media.

How we handled these factors for each type of media is discussed in the following subsections.

Cleanable Media and Peeled-Roll Filter

The cost of new media (CM) for these devices was determined by multiplying the number of media units (NU; bags, rolls, etC.) by the cost per unit (CU) and the number of replacement sets (RS) required in 20 years.

$$
C M=N U \times C U \times R S
$$

The cost of the original set of media was included in the prices of the equipment from the vendors.

The cost of media disposal (CMD) was calculated in three steps. First the volume of a set of compacted media (MVOL) was determined by multiplying the original volume by the percent compaction. Second, the number of media units that could be compacted and packaged for burial per man-hour was estimated (MCOM). The total media disposal cost was then calculated by

$$
\text { CMD }=\left[\left(\text { MVOL } \times \$ 25 / \mathrm{ft}^{3}\right)+(\mathrm{NU} \times \$ 31 / \text { man }-\mathrm{hr} / \mathrm{MCOM})\right] \times(\mathrm{RS}+1)
$$

The man-hours (TCH) required to change each type of media were calculated by estimating the time for two persons to change one media unit and multiplying by the number of units in a complete set. It was assumed that two persons would be involved at any time for safety. The cost for all media changes ( $\mathrm{CMCH}$ ) in 20 years was then calculated by 


$$
\mathrm{CMCH}=\$ 31 / \operatorname{man}-\mathrm{hr} \times \mathrm{TCH} \times(\mathrm{RS}+1)
$$

The RS + 1 factor was used in Equations (2) and (3) because the original set of media mast also be handled and disposed.

Disposable and Rolling Filters

The method for computing media replacement, disposal, and change-out costs for the disposable and rolling filter media types (other than the peeled roll) is identical to that outlined for the cleanable media except the RS and RS +1 factors are replaced with the total number of media sets used, which can be calculated by 6000 shots $x$ LF ( the fraction of media life used by one test shot). The cost-estimating equations are combined and implemented in the FILTER code. FILTER produces the cost and the number of filter changes for the use of any combination of disposable filters as part of the ACS.

Combined System

The media replacement costs for both the cleanabie and disposable devices were combined as shown in the appendices.

\section{MAINTENANCE}

Maintenance costs associated with media replacement were discussed above. The remaining maintenance topics--waste disposal, equipment repairs, and operating labor--are described in the following subsections.

\section{Waste Disposal}

The major waste disposal problem, other than disposing of the media, is disposal of the powder or dust collected in the hoppers used in most of the candidate ACSS. The powder will be a mixture of about the same composition as the airborne particles shown in Table 1. Because the principal component will be DU, precautions must be taken to control the radiological and toxicological hazards. Powder collected in the hoppers will be transferred to a container via some type of airlock valve. The container will have to meet Department of Transportation (DOT) requirements and will probably be a Type A container--a $17 \mathrm{C}, 17 \mathrm{H}$, or $17 \mathrm{EH}$ drum. For purposes of estimation, the following are assumed: 1) a $55-\mathrm{gal}$ drum $\left(7.35 \mathrm{ft}^{3}\right)$ will be used; 2) $2 \mathrm{hr}$ of labor will be involved in 
filling each drum; 3) powder bulk density is equal to that of uranium oxide $\left.\left(1.5 \mathrm{~g} / \mathrm{cm}^{3}\right) ; 4\right)$ a cost of $\$ 25 / \mathrm{ft}^{3}$ includes the container, shipping, and burial costs. Allowing some head-space, each drum will contain about $300 \mathrm{~kg}$ of powder. For example, if $4.9 \mathrm{~kg}$ dust were collected per shot, then the method for computing powder disposal cost is shown in Equation (4).

$$
\begin{aligned}
20-y r \text { Dust Disposal Cost }= & \frac{4.9 \mathrm{~kg} \text { dust to hopper }}{\text { shot }} \times 6000 \text { shot } \times \frac{\mathrm{drum}}{300 \mathrm{~kg} \text { dust }} \\
& \times \frac{\$ 25}{\mathrm{ft}^{3}} \times \frac{7.35 \mathrm{ft}^{3}}{\text { drum }}+\frac{2 \text { man-hr}}{\text { drumfill }} \times \frac{\$ 31}{\text { man-hr }} \\
= & \$ 24,083
\end{aligned}
$$

Because the quantity of powder collected in the hopper varies with the equipment, individual costs of dust disposal for each ACS were estimated in the appendices.

\section{REPAIRS}

The expected repair costs addressed in this study include compressor maintenance, pulse valve rebuilds, cleaning-cycle control board replacement, blower repair, and a 16 -man-hr allowance for miscellaneous annual repairs. The estimating methods for these costs are described below, and the maintenance cost tables in the Appendices contain columns that show which of these repair costs were included in the total cost estimate for each ACS.

For compressor maintenance and repairs, we assumed 8 man-hr/yr would be required. This equates to $8 \mathrm{hr} / \mathrm{yr} \times 20 \mathrm{yr} \times \$ 31 / \mathrm{hr}=\$ 4960$. For miscellaneous annual maintenance or repairs we assumed 16 man-hr/yr or $\$ 9920$. For replacement of the cleaning-cycle control board, we assumed the replacement requires 4 man-hours and the electronics board will cost $\$ 500$. The cost for replacing the board is then $(4 \mathrm{hr} \times \$ 31 / \mathrm{hr})+\$ 500=\$ 624$. Two of the ACSs require the use of a medium pressure air blower instead of a compressor. We assumed blower 
motor repairs may require 16 man-hr and $\$ 1500$ for parts for a total of (16 $\mathrm{hr} \times$ $\$ 31 / h r\rangle+\$ 1500=\$ 1996$. We also assumed that control board and blower repairs would occur only once during the facility life.

Most vendors have advised that the purge valves, which open to emit pulses of compressed air for media cleaning, must be rebuilt frequently. They suggested a preventative maintenance program of rebuilds every 2 years. Usually, each pulse system includes two valves--a solenoid valve and a diaphragm valve-and a rebuild kit costs $\$ 43$ per pair of valves. The worksheets in the appendices list the number of pulse valve pairs per equipment configuration where appropriate. If they are rebuilt every 2 years, the valves will be rebuilt eight times during the equipment life (repair won't be necessary before decommissioning). We have assumed each rebuild will require 8 man-hr; thus, the labor cost is $(8$ rebuilds $) \times(8$ man-hr) $\times(\$ 31 / m a n-h r)=\$ 1984$. The parts cost is (number valve pairs) $\times(\$ 43 /$ kit) $\times(8$ rebuilds) and is computed for each ACS as appropriate in the appendices.

\section{OPERATION}

To estimate the labor cost of operating the ACSs, we have estimated the time involved for daily start-up and shutdown, annual inspection, and annual housekeeping. For the daily operation, we assumed 20 min was required to start and shutdown the existing ACS. For the candidate ACS we added additional time for more complicated equipment. The approach for inspection and housekeeping was similar; one day for housekeeping and a half-day for inspection of the existing system per year. For the other systems additional time was allotted for more complicated equipment. Table 8 lists the amount of time required for daily operating and annual inspection and housekeeping labor for each ACS. The cost of the labor is estimated using Equation (5).

$$
\begin{aligned}
\text { Operation }= & \left.20 \text { yr } \times \frac{\$ 31}{\text { man-hr}} \times \text { (Housekeeping } \frac{\text { day }}{y r}+\text { Inspection } \frac{\text { day }}{y r}\right) \times \frac{8 \text { man-hr }}{\text { day }} \\
& +\left(\text { Operation } \frac{\text { min }}{\text { day }} \times \frac{2006 \text { man-hr}}{y r} \times \frac{\text { day }}{8} \times \frac{h r}{60 \text { min }}\right)
\end{aligned}
$$


TABLE 8. Operating Labor

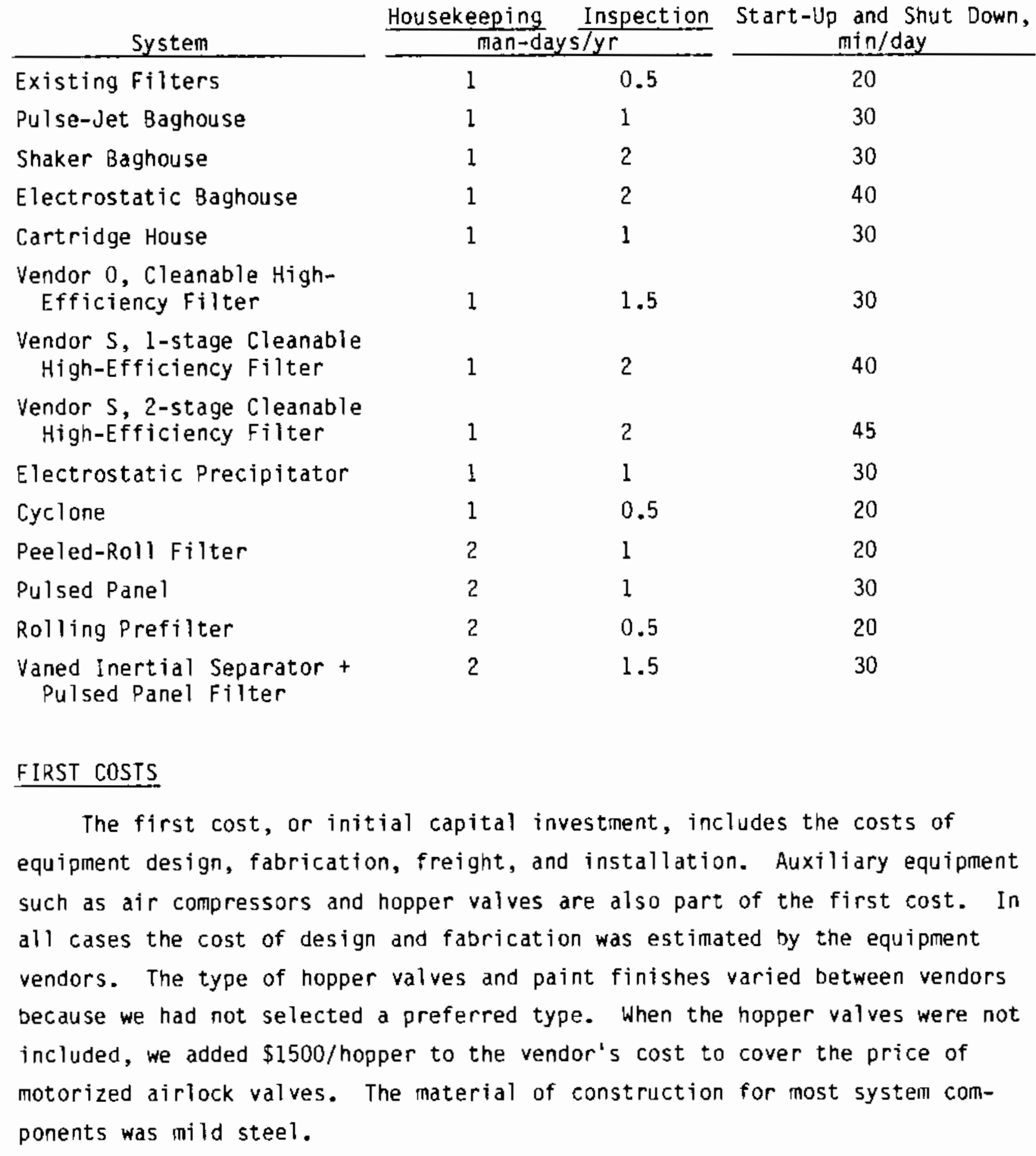


Some vendors supplied us with the cost of ductwork, fan, flow-rate controls, installation, concrete, and electrical work; however, most did not. To put these varied cost estimates on a common ground for installation, we asked Kaiser Engineers Hanford Company, in Richland, Washington, to generate cost estimates. These estimates, summarized in Appendix L, included flow-rate controls, fans for various pressure requirements, air compressors, concrete pads, sheds, drum handiing equipment, freight, ductwork of various types, installation labor, and leak testing in the field. How these were applied to the different ACSs is detailed in the appendix on each type. For all devices except cyclones and precipitators, these estimates were used for the auxiliary equipment, freight, and installation costs. Vendor estimates were used for the cyclones and precipitators.

\section{ELECTRICAL POWER}

Power costs for the range are not part of the direct operating costs to BRL; however, power costs were estimated to provide a basis for selection between ACSs with otherwise comparable costs. Included in our estimates were the power for operating the fan, the control device, and the auxiliary equipment such as compressors or blowers.

Fans

The power cost for operating the fan was estimated directly from the system pressure drop using the method of Burchsted, Fuller and Kahn (1976, p. 24) and very conservative fan and motor efficiencies.

$\underset{\text { Cost }}{\text { Faner }}=$ Air Flow, acfm $\times \frac{2006 \mathrm{hr}}{\mathrm{yr}} \times 20 \mathrm{yr} \times$ pressure drop, in. WG $\times \frac{\$ 0.04}{\mathrm{kWh}}$

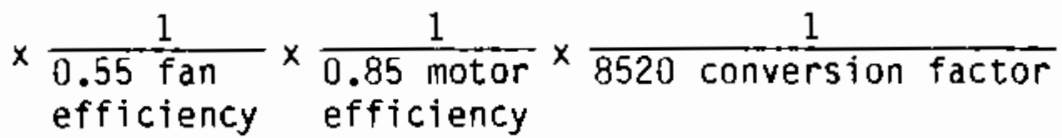

The pressure drop for each ACS was estimated by adding that of each control device to the $2.2 \mathrm{in}$. WG assumed for the range structure and ductwork. 
Cont inuous Equipment

The ESPs are the only continuous users of electricity other than the ventilation fan. Power requirements in terms of kilowatts were obtained from the vendors. The power cost was then computed by multiplying kilowatts by the number of operating hours and the use rate, $\$ 0.04 / \mathrm{kWh}$.

Intermittent Auxiliaries

Most auxiliary devices operate only intermittently during the cleaning cycle. The operating fraction, operating $\mathrm{hr} / \mathrm{hr}$, for these devices was estimated and the horsepower (hp) requirements were furnished by vendors. The power cost was then computed using Equation (7).

$$
\begin{aligned}
\text { Auxiliary } & =\text { Operating Fraction } \frac{h r}{h r} \times \text { Auxiliary hp } \times \frac{2006 h r}{y r} \times 20 y r \\
& \times \frac{0.7457 \mathrm{~kW}}{\mathrm{hp}} \times \frac{\$ 0.04}{\mathrm{kWh}}
\end{aligned}
$$

\section{TOTAL COSTS}

Following the method outlined, the costs over 20 year of acquiring, maintaining, and operating each candidate ACS were computed. The resulting data are tabulated in the appendices according to the type of primary control device. Total costs were estimated for 294 different systems for the 15 types of primary control devices. The most promising configuration for each primary control device was selected and will be discussed in the next section. 


\section{DISCUSSION}

The appendices describe the operating principles of the several types of air cleaning devices listed in Table 3. They also give detailed cost estimates for operating the air cleaning systems for the 20-year expected life. Cost estimates were generated for each device in all of the practical combinations of the existing filter banks. In this section the costs of operating the candidate systems will be compared.

One configuration of each candidate system is used in the comparison. It was stated previously that HEPA filters are assumed to be used as the final stage of filtration to serve as a polishing stage and as a final barrier to particle release. It is further assumed that the HEPA stage will require a medium- to high-efficiency prefilter that will collect the bulk of particles penetrating the first device. This ensures that the HEPA stage can remain functional even if the first filtration device fails catastrophically in an accident that might conceivably be caused by explosive overpressurization of the system during a test firing. When power costs are excluded from consideration, the 20-year equipment, maintenance, and operating costs were most often least expensive when the three existing filter banks were used downstream of the first device. The cost difference between using the last two instead of the three existing filter banks was more significant for systems with total costs over $\$ 1$ million than for the less expensive ones (for which the difference was usually negligible). The system configurations considered for intercomparison are listed in Table 9. Sumarized cost estimates for these systems were computed as shown in Appendix $L$ and the results are shown in Table 9.

The first two columns of Table 9 list the configuration recommended for each device. The initial investment values given include equipment acquisition, installation, freight, ventilation fans, controls, and certain desirable accessories for waste handling (drum scale and truck). The filtration penetration estimates are for the device plus the filter banks as a system. Given the uncertainties in filter efficiency data, the penetration estimates are probably accurate to 1 to 2 orders of magnitude. Maintenance costs include parts and labor for operation, repairs, housekeeping, and removal and installation of 
IABLE 9. Cost Sumary for Candidate Air Cleaning Systems

\begin{tabular}{|c|c|c|c|c|c|c|c|c|c|c|}
\hline \multicolumn{2}{|l|}{ System } & \multirow{2}{*}{\multicolumn{2}{|c|}{$\begin{array}{c}\text { Intt 1al } \\
\text { Investiment, } \\
\text { \$K }\end{array}$}} & \multirow{2}{*}{$\begin{array}{l}\text { Calculated } \\
\text { System } \\
\text { Fractional } \\
\text { Penetration }\end{array}$} & \multicolumn{4}{|c|}{ al $\frac{\text { Maintenance }}{\text { Total }}$} & \multicolumn{2}{|c|}{ Power } \\
\hline Device + & Filter Bank & & & & man-hr & $\$ K$ & & ance, \$K & mWh & $\$ \mathbf{K}$ \\
\hline $\begin{array}{l}\text { Cartridge, Coated Media } \\
\text { Cleanable High-Efficlency Filter, } 1 \text { Stage } \\
\text { Cleanable High-Effictency Filter, } 2 \text { Stage } \\
\text { Electrostatic Baghouse } \\
\text { Baghouse, Pulse-Jet, Standard Felt } \\
\text { Baghouse, Shaker, Standard Sateen } \\
\text { Baghouse, Pulse-Jet, Coated Felt } \\
\text { Cartridge, Standard } \\
\text { Vaned Inertial Separator } \\
\text { ESP } \\
\text { Pulsed Panel }\end{array}$ & $\begin{array}{l}2,3 \\
2,3 \\
2,3 \\
2,3 \\
2,3 \\
2,3 \\
2,3 \\
2,3 \\
2,3 \\
2,3\end{array}$ & $\begin{array}{l}129 \\
187 \\
197 \\
167 \\
157 \\
134 \\
157 \\
129 \\
119 \\
466 \\
100\end{array}$ & & $\begin{array}{l}5.0 \mathrm{E}-08 \\
2.0 \mathrm{E}-07 \\
6.3 \mathrm{E}-07 \\
6.3 \mathrm{E}-07 \\
2.0 \mathrm{E}-09 \\
1.0 \mathrm{E}-08 \\
3.8 \mathrm{E}-10 \\
5.0 \mathrm{E}-06 \\
7.0 \mathrm{E}-06 \\
1.6 \mathrm{E}-06 \\
9.0 \mathrm{E}-06\end{array}$ & $\begin{array}{l}3542 \\
3884 \\
4638 \\
4946 \\
4748 \\
6192 \\
4434 \\
3732 \\
4158 \\
3427 \\
4096\end{array}$ & $\begin{array}{l}8 \\
3 \\
2 \\
3 \\
8 \\
1 \\
8 \\
8 \\
2 \\
1 \\
2\end{array}$ & & $\begin{array}{l}118 \\
124 \\
146 \\
157 \\
155 \\
192 \\
145 \\
123 \\
131 \\
107 \\
129\end{array}$ & $\begin{array}{l}3475 \\
5750 \\
3850 \\
4000 \\
4000 \\
2950 \\
4000 \\
3475 \\
4525 \\
3100 \\
3275\end{array}$ & $\begin{array}{l}139 \\
230 \\
154 \\
160 \\
160 \\
118 \\
160 \\
139 \\
181 \\
124 \\
131\end{array}$ \\
\hline $\begin{array}{l}\text { Peeled-Roll Filter } \\
\text { Cyclone } \\
\text { Standard Rolling Ftlter } \\
\text { Existing System } \\
\text { Extended Surface at Bank } 2\end{array}$ & $\begin{array}{r}2,3 \\
1,2,3 \\
1,2,3 \\
1,2,3 \\
1,2,3\end{array}$ & $\begin{array}{r}253 \\
112 \\
31 \\
20 \\
10\end{array}$ & & $\begin{array}{l}1.1 \mathrm{E}-04 \\
1.1 \mathrm{E}-04 \\
1.1 \mathrm{E}-04 \\
1.1 \mathrm{E}-04 \\
2.5 \mathrm{E}-04\end{array}$ & $\begin{array}{r}8047 \\
8447 \\
10585 \\
12041 \\
16470\end{array}$ & $\begin{array}{l}1 \\
0 \\
1 \\
0 \\
0\end{array}$ & & $\begin{array}{l}250 \\
262 \\
329 \\
373 \\
511\end{array}$ & $\begin{array}{l}4825 \\
6575 \\
2950 \\
3200 \\
2700\end{array}$ & $\begin{array}{l}193 \\
263 \\
118 \\
128 \\
108\end{array}$ \\
\hline System & $\begin{array}{l}\text { Repl acement } \\
\text { Media, \$K }\end{array}$ & Ha & 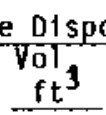 & $\begin{array}{c}\text { osal } \\
\text { Total ope } \\
\text { \$K }\end{array}$ & $\begin{array}{l}\text { erating, } \\
\$ K\end{array}$ & $\begin{array}{l}\text { cludir } \\
\text { Oper } \\
\text { Intt }\end{array}$ & 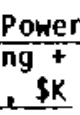 & $\begin{array}{l}\text { Life } \\
\text { Cycle, }\end{array}$ & & \\
\hline $\begin{array}{l}\text { Cartridge, Coated Media } \\
\text { Cleanable High-Efficiency Filter, } 1 \text { Stage } \\
\text { Cleanable High-Effictency Filter, } 2 \text { Stage } \\
\text { Electrostat tc Baghouse } \\
\text { Baghouse, Pulse-Jet, Standard Felt } \\
\text { Baghouse, Shaker, Standard Sateen } \\
\text { Baghouse, Pulse-Jet, Coated Felt } \\
\text { Cartridge, Standard } \\
\text { Vaned Inertlal Separator } \\
\text { ESP } \\
\text { Pulsed Panel }\end{array}$ & $\begin{array}{r}40 \\
14 \\
15 \\
20 \\
60 \\
49 \\
94 \\
122 \\
216 \\
51 \\
249\end{array}$ & $\begin{array}{l}252 \\
204 \\
205 \\
214 \\
259 \\
221 \\
208 \\
347 \\
440 \\
255 \\
477\end{array}$ & $\begin{array}{r}1043 \\
749 \\
776 \\
1075 \\
1400 \\
1247 \\
1100 \\
1528 \\
1807 \\
1004 \\
2008\end{array}$ & $\begin{array}{l}34 \\
25 \\
26 \\
34 \\
43 \\
38 \\
34 \\
49 \\
59 \\
33 \\
65\end{array}$ & $\begin{array}{l}191 \\
163 \\
186 \\
210 \\
257 \\
279 \\
273 \\
294 \\
406 \\
191 \\
443\end{array}$ & $\begin{array}{l}37 \\
41 \\
41 \\
43 \\
42 \\
52\end{array}$ & & $\begin{array}{l}413 \\
429 \\
475 \\
480 \\
540 \\
550 \\
563 \\
567 \\
724 \\
751 \\
759\end{array}$ & & \\
\hline $\begin{array}{l}\text { Peeled- Roll Filter } \\
\text { Cyclone } \\
\text { Standard Rolling Filter } \\
\text { Existing System } \\
\text { Extended Surface at Bank } 2\end{array}$ & $\begin{array}{l}2649 \\
3031 \\
3482 \\
3631 \\
3640\end{array}$ & $\begin{array}{l}3138 \\
3739 \\
4814 \\
5661 \\
4640\end{array}$ & $\begin{array}{l}15345 \\
17607 \\
19633 \\
20920 \\
33064\end{array}$ & $\begin{array}{l}481 \\
556 \\
640 \\
698 \\
970\end{array}$ & $\begin{array}{l}3380 \\
3848 \\
4451 \\
4703 \\
5121\end{array}$ & $\begin{array}{l}363 \\
396 \\
448 \\
472 \\
513\end{array}$ & & $\begin{array}{l}5285 \\
5842 \\
6658 \\
7023 \\
7634\end{array}$ & & \\
\hline
\end{tabular}


filters. The power costs take into account the ventilation fan and any auxiliary equipment required by each system. Media replacement includes the purchase of filter media--both cleanable and disposable. The waste disposal estimate includes the labor involved in compacting, handling, and disposing of filter media and DU containing dust, and the cost of packaging, shipping, and disposing of the waste at a commercial site for low-level radioactive wastes. The totals in the last three columns exclude the cost of power as requested by BRL. The operating cost is the sum of all the costs discussed except the initial procurement. The operating cost plus the initial procurement is the total number of constant dollars that would be spent on the system during the 20-year facility life. Amortizing the operating costs over 20 years at $4 \%$ interest and adding the initial investment yields the life cycle cost estimate in the last column.

The systems in Table 9 were listed in order of ascending 1 ife cycle cost. There were two distinct groupings costwise with about an order of magnitude difference in total cost between the two. The expensive group was characterized by systems where most of the filtration duty is performed using disposable filters. This was true even of the cyclone system because the cyclone's low efficiency for the challenge aerosol puts the filtration burden on the disposable filters. The average life cycle cost for this group was about $\$ 6500 k$.

The less expensive group was characterized by performing most of the filtration with a high-efficiency device using cleanable filters or no filters at all as was the case for the ESP. The average life cycle cost for this group was $\$ 570 \mathrm{~K}$. The most important distinction between the two groups was the cost entailed in the usage and disposal of throw-away filters. Another significant difference, but of lesser impact, was the relative average costs of maintenance, $\$ 139 \mathrm{~K}$ and $\$ 345 \mathrm{~K}$ for the first eleven and the last five systems, respectively. It should also be noted that none of the expensive group of systems met BRL's efficiency criterion of $99.998 \%$ (penetration less than $2.0 \times 10^{-6}$ ), although they were close to meeting the criterion within the accuracy of the available data. The expensive group was then eliminated from further consideration. 
Several of the candidate systems in the less expensive group were eliminated for operational reasons. The vaned inertial separator and pulsed panel systems were eliminated because of the inconvenience and potential inhalation hazard inherent in requiring that the filter panels be changed by entering the contaminated hopper portion of the pulsed panels.

The ESP had the lowest estimated maintenance cost (\$107K) of the remaining systems; however, the ESP had a significantly higher initial cost which outweighed the maintenance advantage. We also suspected that the ESP would be more susceptible to 'puffing', briefly reduced efficiency for the instant of pressurization following a test shot, than would devices using filter media.

The shaker baghouse was eliminated for several reasons. First, it relies entirely on a dust cake for filtration, which would be disrupted during cleaning and probably during each test firing pressure pulse. Smith, Cushing and Carr (1981) showed that shaker efficiency declines significantly following cleaning until such time as a dust cake is rebuilt, which would be a long time in the firing range case because the dust concentration is essentially atmospheric. Second, the pressure pulse could severely damage the unsupported filter bags. The filter bags are inflated by the ventilation airflow and the only supports to the fabric are rings sewn into the fabric at intervals. The brief pressurization following a test shot may overstress an inflated bag. This also applies to the electrostatically augmented baghouse because it has a similar fabric support configuration. An additional drawback of the shaker baghouse was the very large number of bags (960) that would eventually require replacement.

The remaining devices, in order of initial cost, were

1. Cartridge House $(\$ 129 \mathrm{~K})$

2. Pulse-Jet Baghouse $(\$ 157 \mathrm{~K})$

3. Cleanable High-Efficiency Filter (\$187 to 197K)

Table 10 lists the advantages and disadvantages for these remaining candidate systems. 
IABLE 10. Advantages and Disadvantages For Remaining Candidate Systems

\begin{tabular}{|c|c|c|c|c|}
\hline \multirow{7}{*}{ Cartridge House } & \multicolumn{2}{|r|}{ Advantage } & \multicolumn{2}{|r|}{ Disadvantage } \\
\hline & & $\begin{array}{l}\text { Filter removal } \\
\text { from clean side } \\
\text { out of weather }\end{array}$ & 1 & $\begin{array}{l}\text { Standard high } \\
\text { pressure housing } \\
\text { unavailable }\end{array}$ \\
\hline & & $\begin{array}{l}\text { Extensive user } \\
\text { experience }\end{array}$ & & \\
\hline & 3 & $\begin{array}{l}\text { Broad vendor } \\
\text { support }\end{array}$ & & \\
\hline & 4 & $\begin{array}{l}\text { Filters compact } \\
\text { easy to change }\end{array}$ & & \\
\hline & 51 & $\begin{array}{l}\text { Lowest initial } \\
\text { cost }\end{array}$ & & \\
\hline & 6 & Compact housing & & . \\
\hline \multirow[t]{5}{*}{ Pulse-Jet Baghouse } & 19 & $\begin{array}{l}\text { Filter removal } \\
\text { from clean side, } \\
\text { out of weather, }\end{array}$ & 1 & $\begin{array}{l}\text { Walk-in filter } \\
\text { access requires } \\
\text { high bay }\end{array}$ \\
\hline & 2 & $\begin{array}{l}\text { Extensive user } \\
\text { experience }\end{array}$ & 2 & $\begin{array}{l}\text { Filters awkward } \\
\text { to change because } \\
\text { of support cage }\end{array}$ \\
\hline & 3 & $\begin{array}{l}\text { Broad vendor } \\
\text { support }\end{array}$ & 3 & $\begin{array}{l}\text { Highest number of } \\
\text { filter elements } \\
\text { to change }\end{array}$ \\
\hline & 45 & $\begin{array}{l}\text { Standard high } \\
\text { pressure models } \\
\text { available }\end{array}$ & & \\
\hline & 5 & Fewest door seals & & \\
\hline \multirow[t]{6}{*}{ Cleanable High-Efficiency } & 1 & $\begin{array}{l}\text { Convenient filter } \\
\text { changeout }\end{array}$ & 1 & $\begin{array}{l}\text { No existing systems } \\
\text { of comparable capacity }\end{array}$ \\
\hline & 2 & $\begin{array}{l}\text { Fewest filter } \\
\text { elements }\end{array}$ & 2 & $\begin{array}{l}\text { Many door seals that } \\
\text { could leak }\end{array}$ \\
\hline & 3 & Compact housing & 3 & Most expensive \\
\hline & 4 & $\begin{array}{l}\text { Bagout system } \\
\text { for filters }\end{array}$ & 4 & $\begin{array}{l}\text { Single vendor } \\
\text { filter supply }\end{array}$ \\
\hline & 5 & $\begin{array}{l}\text { Eliminate existing } \\
\text { filters with two-stage } \\
\text { housing }\end{array}$ & 5 & $\begin{array}{l}\text { No standard high- } \\
\text { pressure models }\end{array}$ \\
\hline & 6 & $\begin{array}{l}\text { Two stages of filters } \\
\text { with slightly larger } \\
\text { housing }\end{array}$ & 6 & $\begin{array}{l}\text { Single-stage models } \\
\text { had highest pressure } \\
\text { drop }\end{array}$ \\
\hline
\end{tabular}


CONCLUSIONS

The cartridge house system with walk-in filter access is recommended for this firing range application. Initial test firings using the existing filter house resulted in failure of the original joints in the front and back walls, which have since been rebuilt. Because of that failure, the cartridge house will be fabricated of $0.25-i n$. steel and must pass a leak test at the design pressure of +3 psig. We anticipate that the cartridge house will attenuate the pressure pulse transmitted to the filter house.

It is unknown how much the cost of a cartridge house may be increased by the requirement for heavier steel. If the estimated cost is double or triple the costs estimated for this study, it may be well to reconsider the pulse-jet baghouse as the next choice because standard high pressure models are available within the range of prices given in this study (see Tables C.5a and C.6a in Appendix $\mathrm{C}$ ). The cartridge house was recommended as the first choice because of its compact size and small number of filter elements relative to the baghouse. The cleanable high-efficiency filter units were recomended as the third choice because vendor support is limited to the original manufacturer, systems of comparable capacity have not been built before, and there are many door seals subject to leakage.

The existing filter house, or a suitable replacement, should be attached downstream of the cartridge house to enable the use of the $95 \%$-rated prefilters and the HEPA filters. A single cartridge filter was adapted to the prefilter bank of another range for some preliminary testing. After several test shots the filter appeared undamaged from the pressure pulse. 


\section{REFERENCES}

ANSI/ASME. 1980a. Testing of Nuclear Air Cleaning Systems. Standard N510-1980, American Society of Mechanical Engineers, New York, New York.

ANSI/ASME. 1980b. Nuclear Power Plant Air Cleaning Units and Components. Standard N509-1980, ASME, New York, New York.

ASHRAE 52-76. 1976. Method of Testing Air Cleaning Devices Used in General Ventilation for Removing Particulate Matter. American Society of Heating, Ventitating, and Air Conditioning Engineers, New York, New York.

Burchsted, C. A., A. B. Fuller, and J. E. Kahn. 1976. Nuclear Air Cleaning Handbook. ERDA 76-21, for Energy Research and Development Administration, (now U.S. Department of Energy), Washington, D.C.

Chambers, D. R., R. A. Markland, M. K. Clary, and R. L. Bowman. 1982. Aerosolization Characterization of Hard Impact Testing of Depleted Uranium Penetrators, Technical Report ARBRL-TR-02435, U.S. Army Ballistic Research Laboratory, Aberdeen Proving Ground, Maryland.

G1 issmeyer, J.A., and J. Mishima. 1979. Characterization of Airborne Uranium from Test Firings of XM774 Ammunition. PNL-2994, Pacific Northwest Laboratory, Richland, Washington.

Smith, W. B., K. M. Cushing and R. C. Carr. 1981. "Measurement Procedures and Supporting Research for Fabric Filters." In Proceedings of First Conference on Fabric Filter Technology for Coal-Fired Power Plants. CS-2238, Electric Power Research Institute, Pato ATto, California. 


\section{APPENDIX A}

MODELING FILTER EFFICIENCY 


\section{MODELING FILTER EFFICIENCY}

To begin calculating the quantities of particles collected and penetrating the filter media, the particle size range of interest was divided into seven, equally wide, logarithmic size brackets (i.e., the difference between the logarithms of the upper and lower bracket limits is the same for each bracket). The mass fraction of the aerosol in each bracket was obtained from the plot of $\log$ (particle aerodynanic diameter) versus cumulative mass percentage on a probability scale as shown in Figure 1 of the main text. The aerosol mass percent in each bracket was shown in Table 5 for each size distribution. The aerosol in each bracket was assumed to behave as if it were of the same particle size as the midpoint. Data on the collection efficiency of the filters were obtained for the particle sizes associated with the bracket midpoints. Extrapolation beyond the range of literature data was often required. The aerosol mass/bracket was multiplied by the collection efficiency for each bracket to calculate the mass collected. The mass collected from a bracket subtracted from the initial mass was the bracket mass penetrating the filter. Total masses collected and penetrating a filter were obtained by suming the values from each bracket. The penetrating mass per bracket served as the initial mass distribution for the next filter stage. Table A.1 shows an example performance calculation for the three existing filter banks in series using size Distribution 3. The initial mass distribution, fractional efficiency, mass collected and penetrated for each stage and size bracket are shown. Also shown are the overall and cumulative efficiency for each stage.

Table A.1 illustrates how the cost of filter usage was calculated. The table shows the vendor's estimate for the maximum amount of dust that may be collected on a bank of 24 filters at the pressure drop that requires filter replacement. The mass collected by a filter stage was divided by the dust capacity to estimate the fraction of filter life, or life fraction, LF, used in the test. The inverse of the life fraction, 1/LF, is the number of tests the 
filter can be exposed to before replacement and is shown in the table as 'Shot Life'. While this method may be simple, the results in the table for Shot Life were within the range experienced, giving us some confidence in applying the method.

As shown in Appendix 8 , the cost of new media, disposal of the used media, and media change out was estimated as $\$ 267, \$ 1949$, and $\$ 4291$ for stages 1,2 , and 3 , respectively, for one filter bank change. The life fraction multiplied by the bank cost is the cost incurred for the test. This can be multiplied by the number of tests expected in twenty years to estimate the cost during the facility life. The life fraction times the number of tests in 20 years is the number of times the filter bank will be changed. Table A.1 shows the results of these calculations for the existing filter system.

This approach, using a combined bank cost including all the costs associated with replacing a filter bank, was used only for the disposable filters (like those in the existing system) and for the conventional rolling filter. This method was coded for use on a personal computer and is called FILTER. The costs of using the cleanable media and the peeled-roll filter were estimated separately in the worksheets in Appendices B-J and added to the estimated cost of the disposable filters.

A different approach was used to estimate the particle quantity and size distribution exiting a pulse-jet baghouse. This approach is developed in detail in Appendix $C$. 
TABLE A.1. Efficiency and Cost Calculation for Size Distribution No. 3

\begin{tabular}{|c|c|c|}
\hline Size & \multicolumn{2}{|c|}{ Distribution } \\
\hline $\begin{array}{l}\text { Midpoint } \\
\text { Diameter, } \mu \mathrm{m}\end{array}$ & Mass, $\%$ & $\begin{array}{c}\text { Initial } \\
\text { Grams }\end{array}$ \\
\hline $\begin{array}{r}0.1 \\
0.32 \\
1 \\
3.2 \\
10 \\
32 \\
100\end{array}$ & $\begin{array}{r}31 \\
14 \\
15 \\
13 \\
11 \\
7 \\
9\end{array}$ & $\begin{array}{r}1519 \\
686 \\
735 \\
637 \\
539 \\
343 \\
441 \\
\end{array}$ \\
\hline & & 4900 \\
\hline
\end{tabular}

Total

Cumulative Total

\begin{tabular}{|c|c|c|}
\hline $\begin{array}{l}\text { Fractional } \\
\text { Efficiency }\end{array}$ & $\begin{array}{l}\text { Grams } \\
\text { Collected }\end{array}$ & $\begin{array}{c}\text { Grams } \\
\text { Penetrated }\end{array}$ \\
\hline \multirow[t]{2}{*}{$\begin{array}{r}0.0001 \\
0.0001 \\
0.007 \\
0.82 \\
0.983 \\
0.995 \\
0.9972\end{array}$} & $\begin{array}{l}1.519 \mathrm{E}-01 \\
6.860 \mathrm{E}-02 \\
5.145 \mathrm{E}+00 \\
5.223 \mathrm{E}+02 \\
5.298 \mathrm{E}+02 \\
3.413 \mathrm{E}+02 \\
4.398 \mathrm{E}+02\end{array}$ & $\begin{array}{l}1.519 \mathrm{E}+03 \\
6.860 \mathrm{E}+02 \\
7.299 \mathrm{E}+02 \\
1.147 \mathrm{E}+02 \\
9.163 \mathrm{E}+00 \\
1.715 \mathrm{E}+00 \\
1.235 \mathrm{E}+00 \\
\end{array}$ \\
\hline & $\begin{array}{l}1.838 \mathrm{E}+ \\
1.838 \mathrm{E}+\end{array}$ & $3.062 \mathrm{E}+03$ \\
\hline
\end{tabular}

Stage Efficiency

Cumulative Efficiency

3.752E-01

$3.752 E-01$

Max Load, g

Shot Life, shots

6720

Bank Replacement Cost

3.65

$\$ 267$

$20-y r$ Cost by Bank

System 20-yr Cost

Bank Changes in $20 \mathrm{yr}$

$\$ 438,307$

1642

Size

Midpoint Di ameter, um

0.1

0.32

1

3.2

10

32

100

\begin{tabular}{c} 
Bank T \\
\hline Fractiona \\
Efficienc \\
\hline 0.83 \\
0.94 \\
0.987 \\
0.998 \\
0.9994 \\
0.9996 \\
0.9997
\end{tabular}

Total

Cumulative Total

Stage Efficiency

Cumutative Efficiency

Max Load, 9

Shot Life, shots

Bank Replacement cost

20-yr Cost by Bank

System 20-yr Cost

Bank Changes in $20 \mathrm{yr}$

\section{Wo--95\% ASHRAE Filters

Grams Grams

Collected Penetrated

$1.261 E+03 \quad 2.582 E+02$

$6.448 E+02 \quad 4.116 E+01$

$7.204 \mathrm{E}+02 \quad 9.488 \mathrm{E}+00$

$1.144 \mathrm{E}+02 \quad 2.293 \mathrm{E}-01$

$9.158 E+00 \quad 5.498 E-03$

$1.714 \mathrm{E}+00 \quad 6.860 \mathrm{E}-04$

$1.234 E+00 \quad 3.704 E-04$

$2.752 E+03 \quad 3.091 E+02$

$4.591 E+03$

8.990E-01

$9.369 E-01$

9600

3.49

$\$ 1,949$

$\$ 3,352,674$

1720
Bank Three--HEPA Filters

\begin{tabular}{rccc}
\hline $\begin{array}{r}\text { Fractional } \\
\text { Efficiency }\end{array}$ & $\begin{array}{c}\text { Grams } \\
\text { Collected }\end{array}$ & $\begin{array}{c}\text { Grams } \\
\text { Penetrated }\end{array}$ \\
\cline { 2 - 3 } 0.998 & $2.577 \mathrm{E}+02$ & & $5.164 \mathrm{E}-01$ \\
0.99968 & $4.114 \mathrm{E}+01$ & $1.317 \mathrm{E}-02$ \\
0.9999 & $9.487 \mathrm{E}+00$ & $9.488 \mathrm{E}-04$ \\
0.99999 & $2.293 \mathrm{E}-01$ & $2.293 \mathrm{E}-06$ \\
1 & $5.498 \mathrm{E}-03$ & $0.000 \mathrm{E}+00$ \\
1 & $6.860 \mathrm{E}-04$ & $0.000 \mathrm{E}+00$ \\
1 & $3.704 \mathrm{E}-04$ & $0.000 \mathrm{E}+00$ \\
\cline { 2 - 3 } & $3.086 \mathrm{E}+02$ & $5.305 \mathrm{E}-01$ \\
& $4.899 \mathrm{E}+03$ &
\end{tabular}

$9.983 \mathrm{E}-01$

$9.999 \mathrm{E}-01$

9600

31.11

$\$ 4,291$

$\$ 827,502$

$\$ 4,618,483$ 

APPENDIX B

DISPOSABLE FILTERS 


\section{APPENDIX B}

\section{DISPOSABLE FILTERS}

This appendix addresses the disposable (noncleanable, nonreusable) type of filters like those in the existing filter house. The existing filtration unit consists of three banks of disposable filters in series. Twenty-four filters are in each bank--three filters high by eight filters wide. The filters are enclosed in a housing with five access doors as shown in figure 2. The doublewidth, double-inlet fan, with a 60-hp motor, is rated at 24,000 acfm at 11 in. $W G$ and is also enclosed in the housing. Electrically driven opposed-blade dampers are located at the inlet and outlet of the housing to provide some measure of isolation when the system is shutdown. The dampers drive to their full-open position when the fan is started. The housing has a 12-gauge inner wall with reinforcing channels.

\section{EXISTING FILTERS}

The first filter bank consists of Product w2 prefilters that have a pleated cotton media and an ASHRAE rating of $25 \%$. (a) The dimensions of a single filter are $24 \times 24 \times 2$ in., giving a volume of $0.67 \mathrm{ft}^{3}$. Product w2 has a cardboard frame and the media is reinforced with hardware cloth.

The second filter bank contains product w3 filters that have a pleated glass-fiber media reinforced with hardware cloth and cardboard separators. The filter rating is 95\% ASHRAE. (a) The frame enclosing the media is galvanized steel and is $24 \times 24 \times 12$ in., giving a volume of $4 \mathrm{ft}^{3}$.

The first two banks of filters are mounted in a side-loading frame. The second bank is immediately behind the first bank. The first prefilter slides into the frame along a channel. The second prefilter individually mounts in holders, which load at the side of the frame and slide along a track.

(a) These ratings are per ASHRAE 52-76 (1976) Standard Dust Spot Test. 
The final bank consists of HEPA filters, which have a rated collection efficiency of $99.97 \%$ for a $0.3-\mu m$ dioctylphthalate (DOP) test aerosol. The dimensions of a HEPA filter are the same as those of the second prefilter and the media is enclosed in a galvanized steel frame. The media is pleated glassfiber paper that has aluminum separators between the pleats. The filtermounting frame side doors permit personnel entry and individual installation and clamping of the filters.

\section{Alternate Two-Inch-Deep Prefilters}

Four different prefilters sized to replace the existing first bank of prefilters were investigated; however, none appeared to have any efficiency or particle loading advantage so they were not given further consideration in this study.

\section{Alternate High-efficiency Filters}

The use of extended-surface deep-pleat filters was investigated as an alternative to the existing second prefilter with comparable efficiency but higher airflow capacity. Derating these filters to 1000 acfm presumably would allow greater particle loading capacity. Four manufacturers listed extendedsurface filters of varying collection efficiencies and airflow rates in their catalogs. The flow rate increases with the surface area. The loading capacity of the filters is also related to the surface area available and, therefore, the filters with the longest bags (consistent with the space limitations of the current filter framing, 36 in.) were investigated.

All the items investigated are fairly similar. All four filters use fine diameter glass-fiber mats. Three of these extended surface filters had the same pressure drop capability as the existing second prefilter. The filters considered had collection efficiencies of 90\% ASHRAE 52-76 (1976). The filter lengths varied from 30 to $33 \mathrm{in.,}$ and the media surface areas ranged from 66.2 to $120 \mathrm{ft}^{2}$. Figure B.1 illustrates this type of filter. 


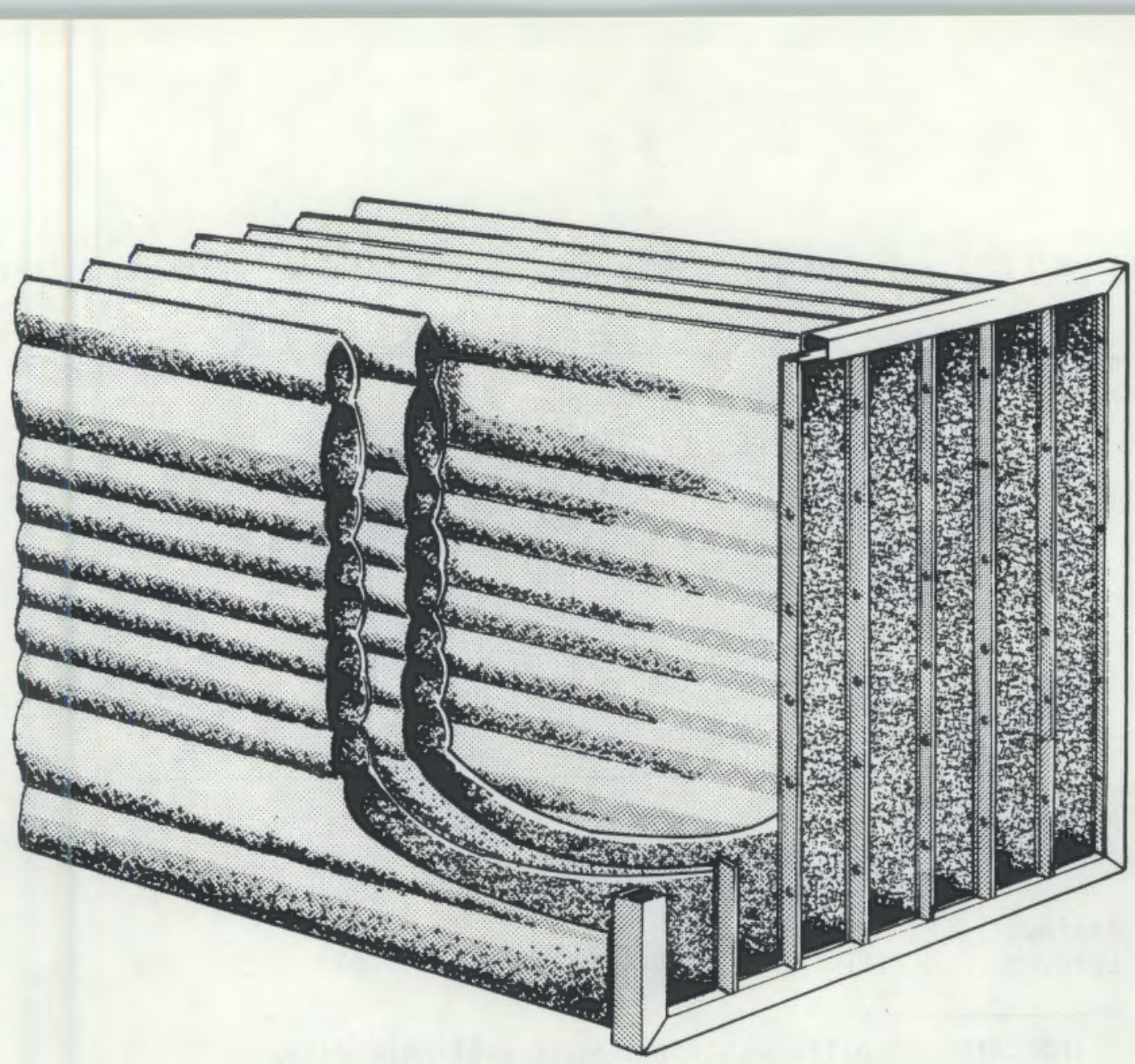

FIGURE B.1. Typical Extended-Surface Filter

\section{EFFICIENCY}

The efficiency data for the existing prefilters and the extended surface filters were extrapolated from the manufacturers literature, and the filterloading data at the maximum operating pressure drops were obtained from communications with the manufacturers. Efficiency data for the generic HEPA filter data were obtained from Burchsted, Fuller, and Kahn (1976, Figure 2.8). The data are summarized in Table B.1.

\section{COST ESTIMATING}

The disposal cost of the disposable filters depends largely on their compacted volume. Recently, each of the existing first and second prefilters were compacted into a 55-gal. drum (internal volume $7.35 \mathrm{ft}^{3}$ ). The initial volume for this quantity of filters was $84 \mathrm{ft}^{3}$. The filters compacted to 0.088 of their original volume, which was the value used for the second prefilters. 
TABLE B.1. Fractional Efficiency and Loading Data for Existing Filters

\begin{tabular}{|c|c|c|c|c|}
\hline \multirow[b]{2}{*}{$\begin{array}{c}\text { Particle } \\
\text { Diameter, } \\
\mu m\end{array}$} & \multicolumn{4}{|c|}{ Fractional Efficiency } \\
\hline & $\begin{array}{c}\text { First } \\
\text { Prefilter } \\
\end{array}$ & $\begin{array}{l}\text { Second } \\
\text { Prefilter } \\
\end{array}$ & $\begin{array}{c}\text { HEPA } \\
\text { Filter } \\
\end{array}$ & $\begin{array}{c}\text { Extended } \\
\text { Surface } \\
\text { Product Al } \\
\end{array}$ \\
\hline $\begin{array}{c}0.1 \\
0.32 \\
1.0 \\
3.2 \\
10.0 \\
32.0 \\
100.0\end{array}$ & $\begin{array}{l}0.0001^{\star} \\
0.0001^{\star} \\
0.007^{\star} \\
0.82 \\
0.983 \\
0.995 \\
0.9972\end{array}$ & $\begin{array}{l}0.83^{\star} \\
0.94^{\star} \\
0.987^{\star} \\
0.998 \\
0.9994 \\
0.9996 \\
0.9997\end{array}$ & $\begin{array}{l}0.998 \\
0.99968 \\
0.9999^{\star} \\
0.99999^{\star} \\
1.0^{\star} \\
1.0^{\star} \\
1.0^{\star}\end{array}$ & $\begin{array}{l}0.62^{\star} \\
0.77 \\
0.92 \\
0.99^{\star} \\
0.999^{\star} \\
0.9999^{\star} \\
0.99999^{\star}\end{array}$ \\
\hline & \multicolumn{4}{|c|}{ Loading Data } \\
\hline $\begin{array}{l}\text { Maximum } \\
\text { Pressure } \\
\text { Drop, in. WG }\end{array}$ & 1.0 & 4.0 & 4.0 & 4.0 \\
\hline $\begin{array}{l}\text { Maximum } \\
\text { Load, g }\end{array}$ & 280 & 400 & 400 & 750 \\
\hline
\end{tabular}

* indicates an extrapolation beyond available data.

Because of an error early in this study, a compacted fraction of 0.067 was used for first prefilters. (This resulted in underestimating the cost of changing this bank by $\$ 7$, which was not considered to be of serious consequence.) For the HEPA filters, we assumed the compacted volume was $25 \%$ of the original volume--higher than for the others because the casing is heavy sheetmetal rather than cardboard or light sheetmetal. A compacted volume of $10 \%$ was assumed for the extended surface filter. The cost of replacing a bank of each filter type was calculated as shown in Table B.2. These costs served as bank replacement cost inputs to FILTER.

The initial investment costs for these systems were just the cost of the airflow controls, \$10K. It was assumed that the extended surface filter would fit in the existing filter frame. Table $B .3$ shows the estimates for 20 year's maintenance, which was the same for both approaches. Filter replacement and disposal costs were omitted because they were estimated by FILTER. The only item under repairs was the 16 man hour annual allowance for miscellaneous unspecified repairs. 
TABLE B.2. Cost of Replacing Banks of Disposable Filters

First Prefilter, 25\% ASHRAE

New filters $=24 \times \$ 6.15=$

Change out labor $=2 \mathrm{man}-\mathrm{hr} \times \$ 31 / \mathrm{man}-\mathrm{hr}=$

Compactor operater $=1 \mathrm{man}-\mathrm{hr} \times \$ 31 / \mathrm{man}-\mathrm{hr}=$

Disposal $=16 \mathrm{ft}^{3} \times 0.067 \times \$ 24.26 / \mathrm{ft}^{3}=$

Second Prefilter, 95\% ASHRAE

New filters $=24 \times \$ 67.50=$

Change out labor $=2$ man-hr $\times \$ 31 /$ man-hr $=$

Compactor operatgr $=2$ man-hr $\times \$ 31 / m a g n-h r=$

Disposal $=96 \mathrm{ft}^{3} \times 0.088 \times \$ 24.26 / \mathrm{ft}^{3}=$

HEPA

New filters $=24 \times \$ 130=$

Change out labor $=16 \mathrm{man}-\mathrm{hr} \times \$ 31 / \mathrm{man}-\mathrm{hr}=$

Compactor operatgr $=3$ man-hr $\times \$ 31 /$ man-hr $=$

Disposal $=96 \mathrm{ft}^{3} \times 0.25 \times \$ 24.26 / \mathrm{ft}^{3}=$

Extended Surface Filter, 90\% ASHRAE

New Filters $=24 \times \$ 102=$

Change out labor $=4$ months $\times \$ 31 /$ man-hr $=$

Compactor operator $=2$ man-hr $\times \$ 31 / \mathrm{man}-\mathrm{hr}=$

Disposal $=0.1 \times 24 \times 2 \mathrm{ft} \times 2 \mathrm{ft} \times 2.7 \mathrm{ft} \times$ $\$ 25 / \mathrm{ft}^{3}=$

TABLE B.3. Disposable Filter Twenty-Year Maintenance

\begin{tabular}{|c|c|c|c|c|c|c|c|c|}
\hline Derice & Type & $\begin{array}{l}\text { Repair } \\
\text { Cocles } \\
\text { C P A E B }\end{array}$ & $\begin{array}{l}\text { Misc. } \\
\text { Repatrs, } \\
\quad \$ K\end{array}$ & $\begin{array}{c}\text { Housekeepting } \\
\text { Inspect1on, } \\
\text { day/yr }\end{array}$ & $\begin{array}{l}\text { Start-up } \\
\text { Shutdown, } \\
\text { min/day }\end{array}$ & $\begin{array}{c}\text { Gperating } \\
\text { Labor, } \\
\$ K\end{array}$ & 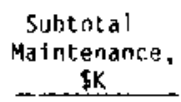 & $\begin{array}{c}\text { Auxilfacy } \\
\text { Power } \\
-5 k \\
\end{array}$ \\
\hline Existing Filter Banks & & I & 9.92 & 1.5 & 20 & 59.26 & 64 & 0.00 \\
\hline Extended-Surface F1lter & Bank 2 & 1 & 9.92 & 1.5 & 20 & 59.26 & 69 & 0.00 \\
\hline
\end{tabular}


Table B.4 shows various performance data and total costs for each disposable filter bank combination. The disposable filter replacement cost is the $20 \mathrm{yr}$ cost of new filters and disposal of used filters as estimated by FILTER. The total number of times a filter bank replacement may occur and the overall system filtration efficiency was also estimated by FILTER and iisted in the table. System pressure drop accounts for the building ductwork and the maximum load on the disposable filters. The fan cost estimated for two of the cases was for upgrading the existing fan for the required vacuum capacity. Total maintenance and acquisition costs for each combination are the sum of maintenance from Table B.3, the airflow control cost (\$10K), disposable filter useage and fan costs. Power costs are calculated and added to the equipment and maintenance cost.

The estimated cost for operating the existing system during 20 years and 6000 shots of $4.9-\mathrm{kg}$ ammunition was $\$ 4618 \mathrm{~K}$ for filter replacement, $\$ 69 \mathrm{~K}$ for maintenance and operation, \$1OK to upgrade the fan, and \$10K for flow controls, adding to a total of $\$ 4707 \mathrm{~K}$ without power. Power would add about another $\$ 128 \mathrm{~K}$.

Cost estimates were generated for operating with fewer filter banks, but they are to be ignored because the combined efficiency is well below the criterion. The efficiency estimated for the existing system was $99.989 \%$, which is also below the criterion but is probably a conservative estimate. An estimate was made of the effect of underestimating the efficiency of the first prefilter in the $0.1-, 0.32-$, and 1- $\mu m$ size brackets. These efficiencies were increased from 0.0001 to $0.5,0.0001$ to 0.1 , and 0.007 to 0.5 for those brackets, respectively. The resulting filter replacement cost decreased from $\$ 4618 \mathrm{~K}$ to $\$ 3251 \mathrm{~K}$, which is still a very sizeable cost when compared to the cleanable media systems with a high-efficiency primary stage.

The costs of some hypothetical three-bank combinations were estimated. An ideal system might be to use two stages of $95 \%$ ASHRAE prefilters followed by a HEPA stage where the prefilters would cost the same as the $25 \%$ ASHRAE prefilter. For this system the overall efficiency increased to near the criterion, 0.999982 , and the cost for 20 years was estimated at $\$ 1.5 \mathrm{M}$. A second 
TABLE B.4. Twenty-Year Total Costs by Filter Bank Combination for Disposable Filters

\begin{tabular}{|c|c|c|c|c|c|c|c|c|c|c|c|}
\hline & $\begin{array}{c}\text { Bank } \\
\text { Combination }\end{array}$ & $\begin{array}{l}\text { Disposable } \\
\text { Filter } \\
\text { Replacerent }\end{array}$ & $\begin{array}{l}\text { Nunber } \\
\text { Bank } \\
\text { Changes } \\
\end{array}$ & $\begin{array}{c}\text { System } \\
\text { Efficiency, } \\
\quad \underline{B}\end{array}$ & $\begin{array}{c}\text { 5ystem } \\
\Delta \mathrm{P}, \\
\text { in. } W G \\
\end{array}$ & $\begin{array}{c}\text { Fan } \cos t, \\
\$ K\end{array}$ & $\begin{array}{c}\text { Total } \\
\text { First } \\
\text { Cost, \$k }\end{array}$ & $\begin{array}{l}\text { Fan } \\
\text { Power, } \\
\text { \$K }\end{array}$ & $\begin{array}{c}\begin{array}{c}\text { Equipment } \\
\text { and } \\
\text { Maintenance, }\end{array} \\
\text { 员 }\end{array}$ & $\begin{array}{l}\text { Power, } \\
\text { \$K }\end{array}$ & $\begin{array}{l}\text { Total, } \\
\$ x\end{array}$ \\
\hline $\begin{array}{l}\text { Existing Filter } \\
\text { Banks }\end{array}$ & $\begin{array}{r}1.2 .3 \\
2.3 \\
3 \\
1.3\end{array}$ & $\begin{array}{r}4618 \\
6422 \\
13132 \\
8640\end{array}$ & $\begin{array}{l}3555 \\
3062 \\
3061 \\
3553\end{array}$ & $\begin{array}{l}99.989 \\
99.989 \\
99.932 \\
99.932\end{array}$ & $\begin{array}{l}13.2 \\
12.2 \\
11 \\
11\end{array}$ & $\begin{array}{r}10 \\
10 \\
0 \\
0\end{array}$ & $\begin{array}{l}20 \\
20 \\
10 \\
10\end{array}$ & $\begin{array}{l}128 \\
118 \\
106 \\
106\end{array}$ & $\begin{array}{l}4707 \\
6511 \\
8719 \\
8719\end{array}$ & $\begin{array}{l}12 B \\
118 \\
106 \\
106\end{array}$ & $\begin{array}{l}4835 \\
6629 \\
8826 \\
8826\end{array}$ \\
\hline $\begin{array}{l}\text { Extended-Surface } \\
\text { Filter at Bank } 2\end{array}$ & 1.2 .3 & 5041 & 2893 & 99.975 & 11.2 & & 10 & 108 & 5120 & 108 & 5228 \\
\hline
\end{tabular}


hypothetical system with one bank of $95 \%$ ASHRAE prefilters followed by two HEPA banks resulted in an estimated efficiency and cost of 0.99999979 and $\$ 6.4 M$, respectively.

Using the extended surface filter resulted in an estimated 20-year total cost higher than that of the existing system because the unit cost of the filter is higher than the 95\% ASHRAE filter it replaces. Apparently, the extendedsurface filter would result in a cost saving only if its unit cost were less than the filters replaced, and it had equal or better performance.

It has been assumed for this study that the existing housing and one or more of its filter banks would be used in the prototype system. Two problems, however, are that there are no flow controls and the fan is probably undersized. A third problem is that the housing is always at the maximum fan vacuum capacity because the fan is in the interior of the housing. If fan bearings are inspected while the fan is operating, personnel must enter the housing--a difficult task while it is under vacuum.

If the filter housing is to be used, the fan vacuum capacity probably must be increased. The fan manufacturer indicates that the fan vacuum capacity can be increased to around $13 \mathrm{in}$. WG by using a larger motor. If the vacuum requirement is greater still, the existing fan should be removed and the replacement fan should be a single-inlet type located outside the housing. Flow controls in the form of a vortex damper or speed control would be incorporated. This would enable external inspection of the fan and the housing would be only at the vacuum absolutely required for the airflow at any set of filter loading conditions.

Two additional factors need to be considered. One is the ability of the housing to handle the increased structural load of the vacuum. The other is the ability of the housing to remain leak tight during the 3-psi pressure pulses. However, if another filter device is used upstream, the pressure pulse will probably be dampened in magnitude and time.

If it becomes desirable to replace the filter housing, more vendor inquiries would be necessary to supplement the cost analysis. One vendor indicated they would furnish a bag-in/bag-out side-loading filter housing of T-304 
stainless steel that would meet ANSI Standard 509 and 510 specifications

(ANSI/ASME 1980a; ANSI/ASME 1980b) for aerosol and pressure leakage in nuclear facility air cleaning systems. If furnished with the same type of filters as the existing system, the new housing would cost about $\$ 38.5 K$ with 24 filters per bank. Alternate sizes discussed were 18 and 48 filters per bank at $\$ 28.5 \mathrm{~K}$ and $\$ 80 K$, respectively.

\section{REFERENCES}

ANSI/ASME. 1980a. Nuclear Power Plant Air Cleaning Units and Components. Standard N509-1980, American Society of Mechanical Engineers, New York, New York.

ANSI/ASME. 1980b. Testing of Nuclear Air Cleaning Systems. Standard N510-1980, American Society of Mechanical Engineers, New York, New York.

ASHRAE 52-75. 1976. Method of Testing Air Cleaning Devices Used in General Ventilation for Removing Particulate Matter. American Society of Heating, Ventilating, and Air Conditioning Engineers, New York.

Burchsted, C. A., A. B. Fuller, and J. E. Kahn. 1976. Nuclear Air Cleaning Handbook. ERDA 76-21, Energy Research and Development Administration, Richland, Washington. 

APPENDIX C

BAGHOUSES 


\section{APPENDIX C}

\section{BAGHOUSES}

\section{DESCRIPTION}

A device where particles are removed from the airflow by entrapment on a fabric substrate shaped in the form of tubes or envelopes is commonly called a baghouse. Depending on the vendor's choice of total fabric area and the length of the bags, the number of bags required ranged from 110 to 960 with an average of about 264 bags and $4400 \mathrm{ft}^{2}$ of $\mathrm{cloth}$. The vendors consulted recommended three types of baghouses: pulse-jet, shaker, and electrostatically enhanced. Each of these types are described in greater detail following a brief discussion of the fabrics used.

\section{$\underline{\text { FABRICS }}$}

For ambient temperature filtration, two main fabric types are used--felt and woven. Several compositions of these types are available with special characteristics suited for the application, such as resistance to acid fume. As a rule, felt bags are used in pulse-jet baghouses and woven bags are used in shaker baghouses because of the different requirements and stresses on the fabric.

The woven fabrics come in a few different weaves, but all require the buildup of a dust cake, which performs the actual filtration. The fabric serves as a support for the cake, as shown in Figure C.1. After a cake is established, the efficiency is very high compared to other devices. If immediate high efficiency is required or the dust loading is very light, a dust is artificially entrained in the airstream to coat the fabric. The dust, called a filter aid, is often lime.

The felt is made by needling fibers into the weave of a strong woven backing, or skrim. Particle filtration occurs both on the fibers and on the dust cake that eventually builds as illustrated in Figure C.1. Once a dust cake is established, it is hypothesized that particle penetration through these fabric 

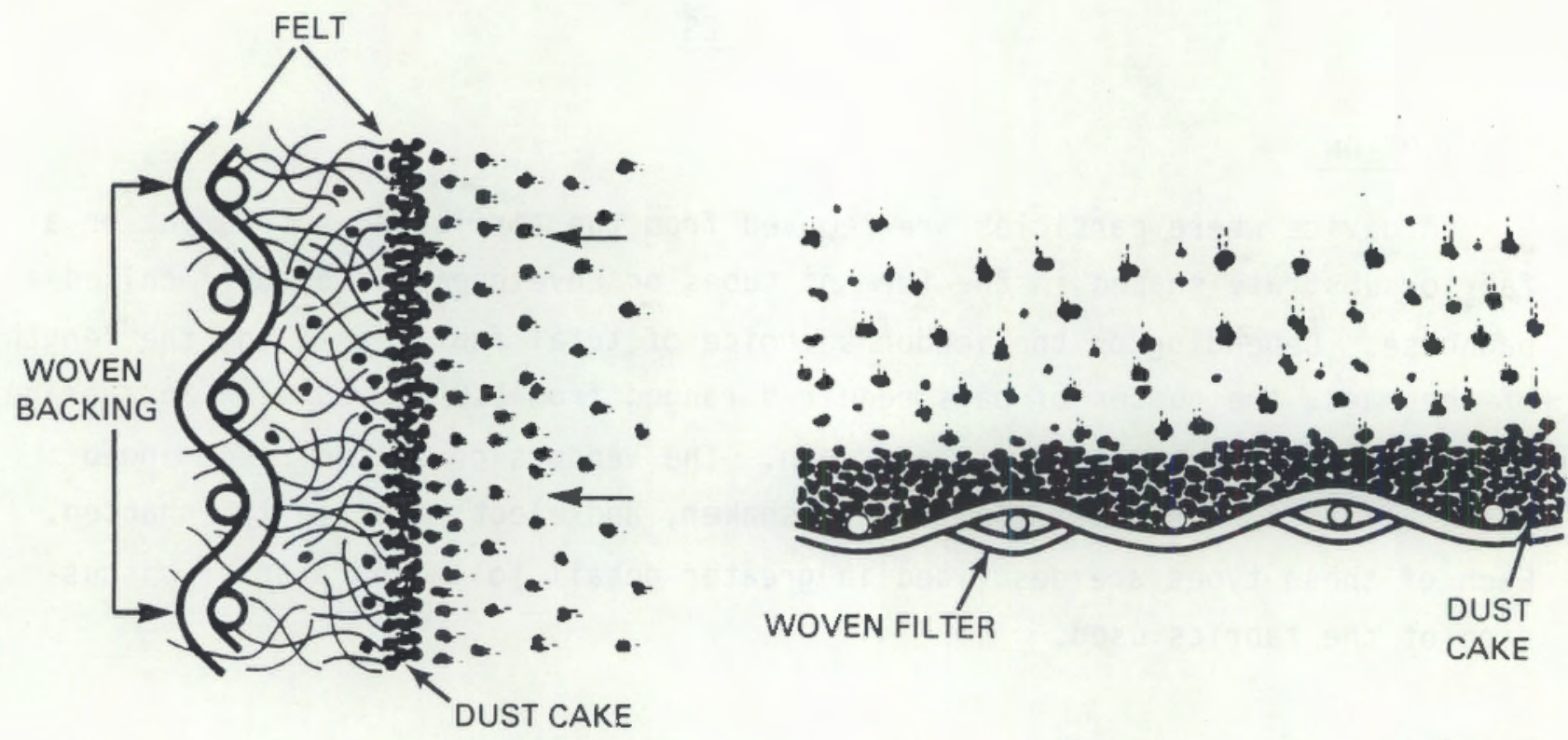

FIGURE C.1. Particle Collection on Woven and Felt Bag Media (after Beachler and Jahnke 1981)

types is caused by seepage due to the shock of cleaning. It is reasonable to presume that the pressure wave from the test firings will also cause seepage.

One fabric manufacturer attempts to retard the seepage by applying a type of Teflon ${ }^{\circledR}$ coating to the surface of the fabric. The coating has been demonstrated to filter and retain the particles on the outer surface of the fabric. When the coated bags are cleaned, the bag surface is smooth compared to the cakey surface of the other bag types. Presumably, this type of media would retain less surface contamination on cleaning than the other types. The manufacturer claims longer bag life, higher efficiency, lower operating pressure drop, and a reduction in the cloth area required. A drawback to this fabric is its higher cost and fragility. The coated polyester felt bags, as they are known, cost about six times as much as conventional polyester felt bags. This

(3) Registered trademark of the E. I. Du Pont de Nemours Co., Wilmington, Delaware. 
cost study was done for both conventional and coated bags. When coated bags are installed, care must be taken not to abrade the coating on the exterior of the bags.

\section{PULSE-JET}

In the pulse-jet baghouse the media is usually in the shape of a long cylindrical tube; closed at one end with the open end anchored at the top in a tube sheet. Air usually passes from the outside of the bag to the inside and out the open end. The interior of the bag is supported by a heavy-gauge wire cage. Figure C.2 is a cutaway drawing of the typical pulse-jet baghouse. Collected dust is cleaned from the fabric periodically by pulses of compressed air directed downward through a venturi at the open end of the bag. The shock of the pulse dislodges particles that have agglomerated to a large enough size to fall into the hopper or to a point lower on the bag. One or more rows of bags are cleaned at a time while the baghouse is online. The snapping of the fabric back onto the cage is one main cause of fabric wear. Another cause of fabric wear is the abrasion by particles. Most baghouses have inlet diffusers to prevent abrasion caused by the high velocity impingement of particles on the fabric.

The dirty-air inlet may be in the hopper region or just below the tube sheet so that the airflow along the bags can be either generally upwards or downwards. Access to the baghouse interior is usually through an inspection hatches at the hopper and at the clean-air plenum on the top. Bags are usually inspected and changed from the clean-air side, which is through the top access. There are usually several hinged doors on the clean-air plenum to gain access to all the bags. This design would require a covering of some kind to permit all-weather access. An alternate design, offered by all but one vendor, is to have a walk-in clean air plenum. The plenum, with a single entry, would be tall enough for the removal of the cages. The walk-in plenum is preferred to enable all-weather access and to reduce the potential for leaky seals; however, the baghouse housing is taller than otherwise, but the access elevation remains the same with or without the walk-in. 


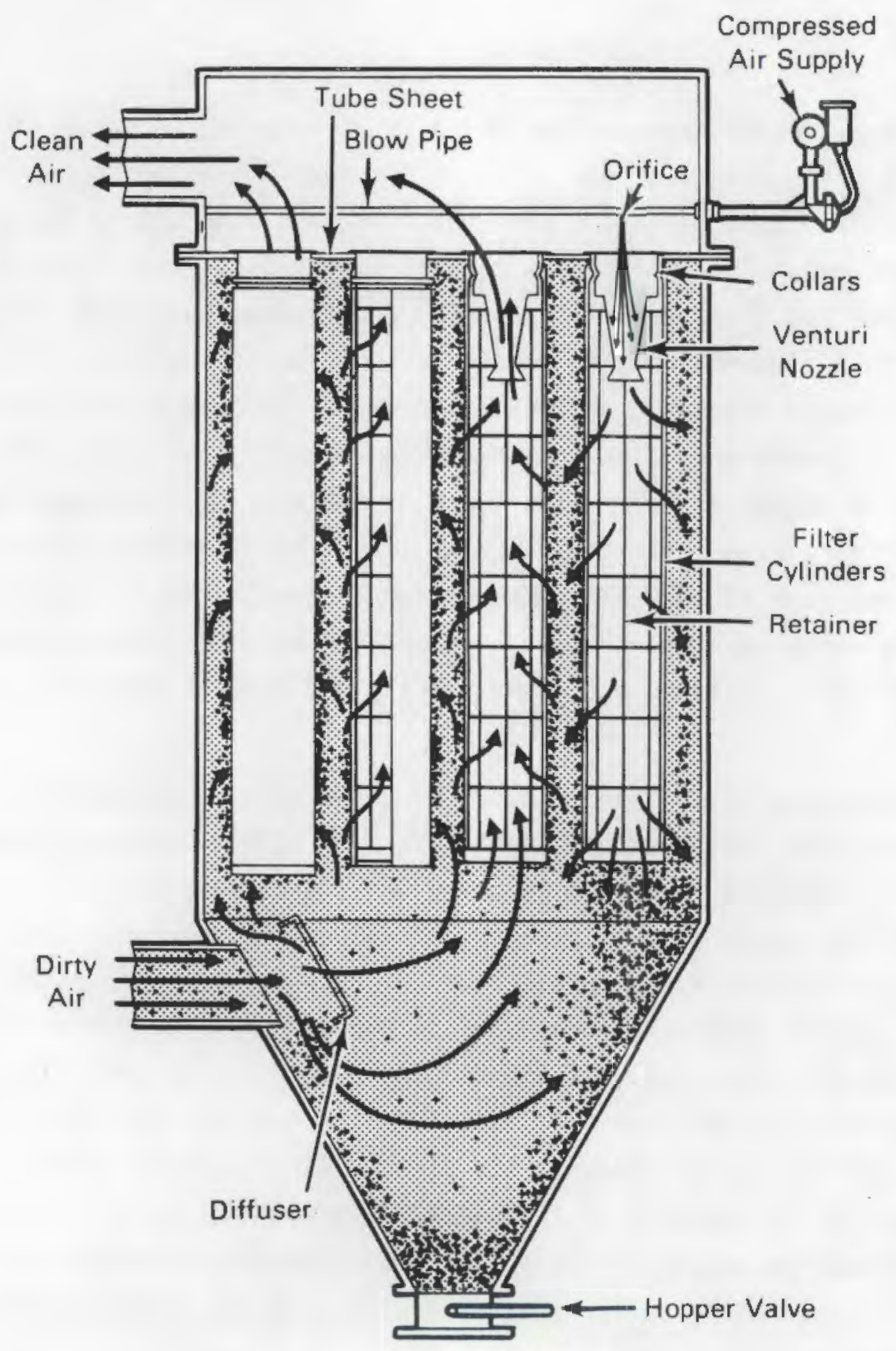

FIGURE C.2. Pulse-Jet Baghouse Cross Section 
One manufacturer builds a pulse-jet baghouse with the bags inverted over a tube sheet. The airflow is from inside to the outside of the bag. The compressed-air pulse nozzle and venturi are at the bottom of the bag. The cleaning pulse is directed downward through the venturi, creating a suction on the bag, which blows the dirt laden air into a vented hopper specially designed to prevent reentrainment. At the hopper vent, a single bag discharges to atmosphere, but could be ducted back to the clean-air plenum. The top of the walk-in plenum is at the same elevation as the top of the bags, thus reducing the headroom requirement of the other pulse-jet baghouses. The walkway inside the plenum is between the rows of bags, which allows close inspection, but possibly increases the potential for exposure during bag changes.

Most baghouses are constructed of 12- to 14-gauge steel; however, most vendors recommended thicker steel and additional bracing to withstand the pressure pulses. Some vendors manufacture cylindrical baghouses to American Society of Mechanical Engineers (ASME) Pressure Vessel Codes like that pictured in Figure C.3. This type is also available with a walk-in plenum, but the number of bags is limited, so two units in parallel would be required.

The air for cleaning pulses is usually provided by an external air compressor. The compressed air must be dry so freezing condensate will not damage the pulsing valves or the fabric. The compressor packages selected for this study were complete with air driers and heat lagging on the piping. Insulation and heating are also available for the valve mechanisms or the entire baghouse. This option was generally ignored in this cost study unless it was part of the standard unit. The baghouses come equipped with standard cleaning cycle timers that operate at regular intervals or on a demand signal such as pressure drop.

One vendor recommended a baghouse with a high-pressure blower instead of a compressor. The blower pumps air into a manifold rotating in the horizontal plane above the tube sheet with nozzles aligned above the openings of a group of bags. The blower draws its supply from the clean-air plenum. Similar designs are available from other vendors. In one design the rotating manifold also blocks normal airflow in adjacent bags to attempt to prevent particles from being pulsed onto the neighboring bags. Because of the rotating manifold, 


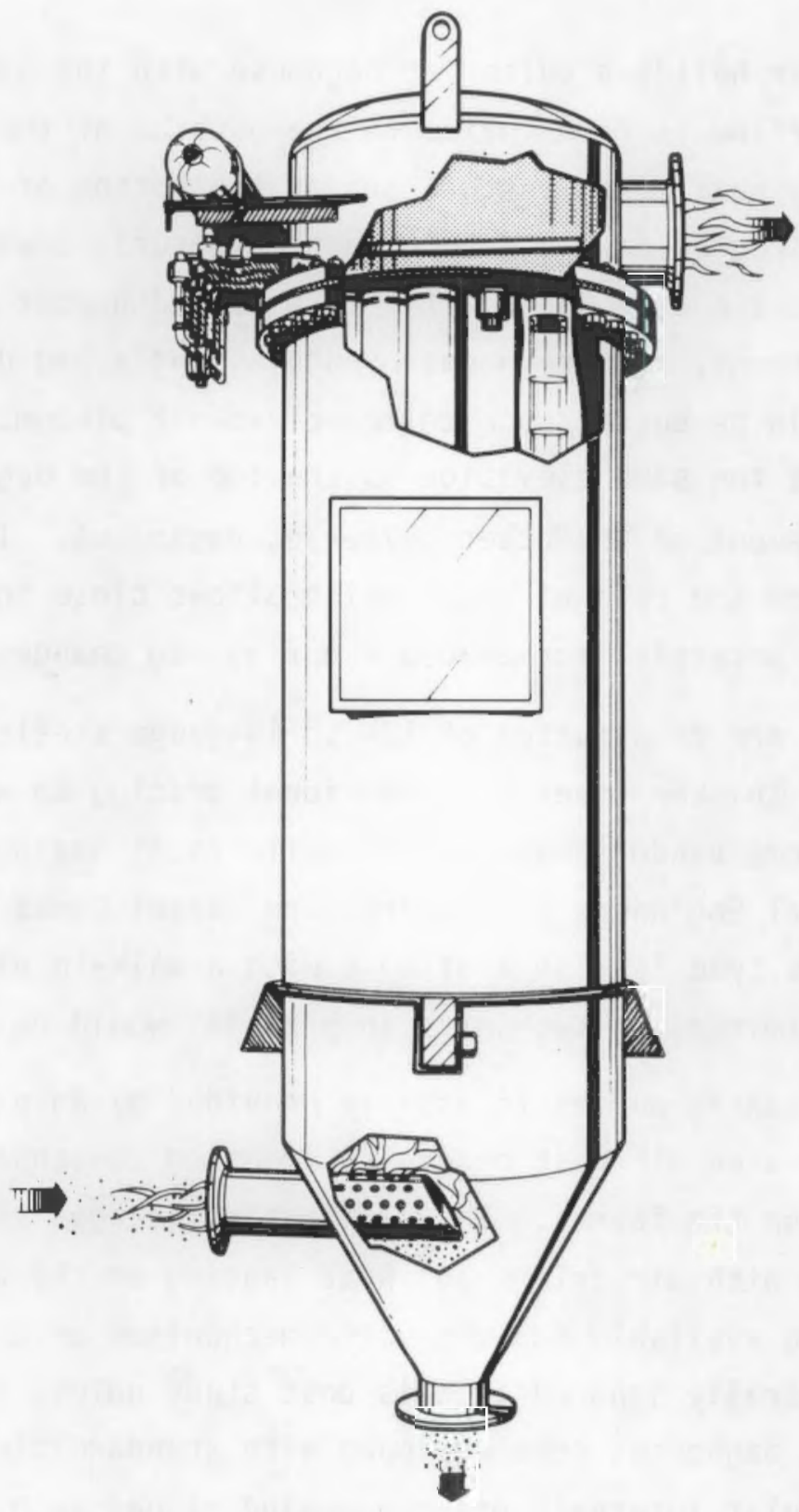

FIGURE C.3. High Pressure Pulse-Jet Baghouse

this type of baghouse is cylindrical and is commonly offered with walk-in plenums and cyclonic inlet sections for the removal of very large particles.

SHAKER

In a shaker baghouse, the bags are suspended at the top closed end and the open end is anchored in a tube sheet at the bottom, directly above the hopper, 
as shown in Figure C.4. The airflow is from inside to outside the bag and particles are collected in a dust cake in the bag interior. Each row of bags is anchored at the top on a boom. When cleaning is required, a mechanism causes the boom to rock from side to side, shaking the bags and causing agglomerated particles to fall to the hopper. A shaker unit large enough for 24,000 acfm would be assembled from modules or compartments, each with its own hopper, because the compartment being cleaned and its hopper must be taken offline. The bags are accessed for inspection and changing through a hatch in the side of each compartment that opens onto a walkway between the rows of bags. Generally, larger amounts of cloth are used in shaker baghouses than in pulse-jets because woven fabrics are used for the bags.

Filtration relies on the built-up dust cake; thus, efficiency decreases when bags are cleaned. Presumably, the pressure pulse of the test firing would also dislodge the cake, decreasing efficiency. The one vendor recominending this type thinks that sufficient dust cake would remain after the firing and cleaning so that recoating the bags artificially would not be required.

\section{ELECTROSTATICALLY ENHANCED}

The electrostatically enhanced baghouse places a static charge on the particles to enhance collection efficiency and agglomeration. Figure C.5 shows a cutaway of the baghouse showing a charging section beneath the collection bags. The charging section is like the first stage of a two-stage tubular electrostatic precipitator described in Appendix F. Above the charging section, the bags are inverted over the tube sheet and the airflow is from inside to outside the bag. The bag fabric is a standard felt; polyester felt is recommended for this application. The compressed air nozzle and venturi are just below the tube sheet and mouths of the bag and above the charging section. The cleaning pulse is directed downward through the venturi, creating a suction on the bag, and blows the dirt-laden air through the charging section to the hopper. The air jet also cleans the charging section. In addition to access openings like those of a pulse-jet baghouse, a third access door is provided in the charging section to facilitate maintenance there. 


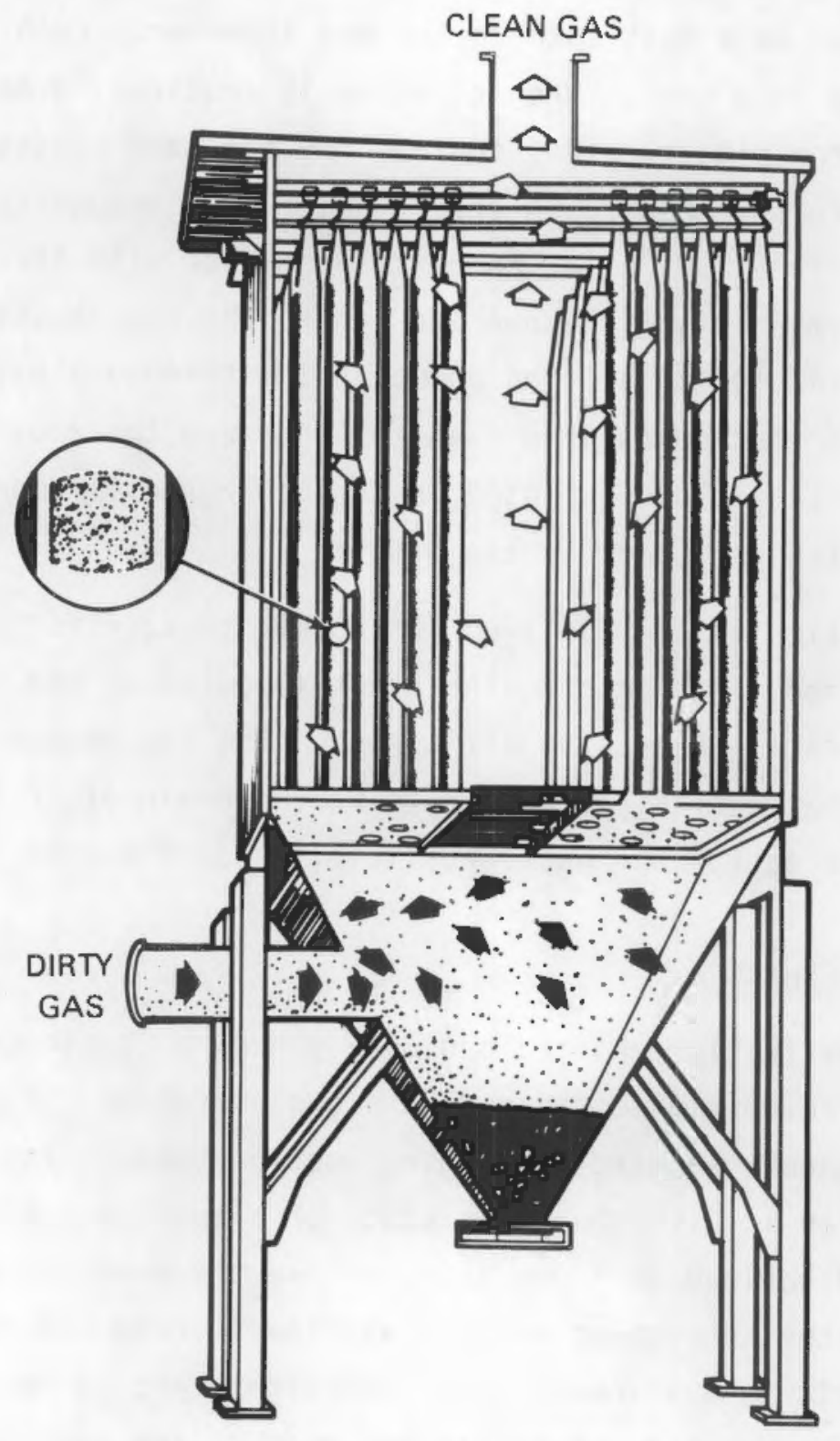

FIGURE C.4. Cross Section of a Shaker Baghouse (after Beachler and Jahnke 1981) 


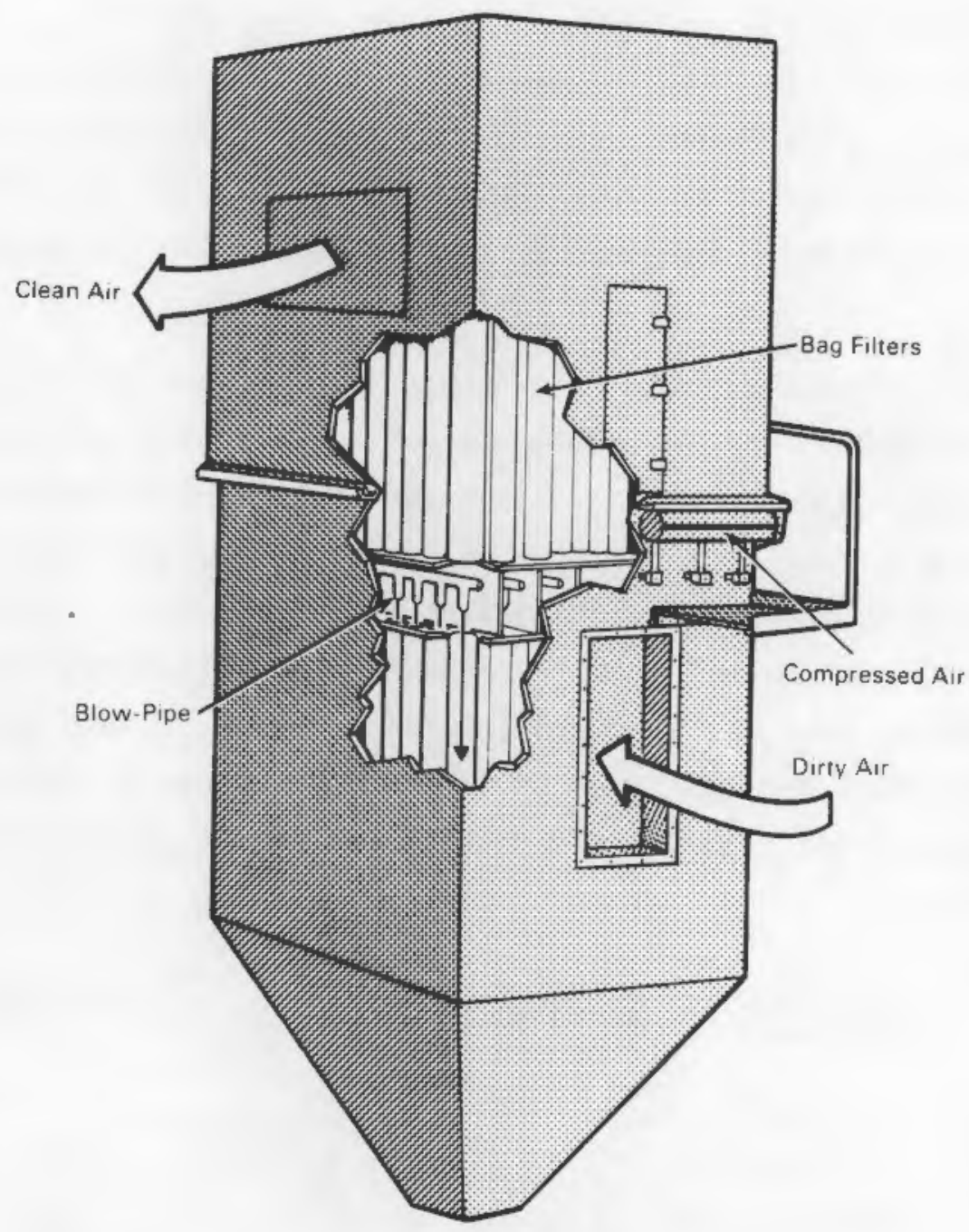

FIGURE C.5. Electrostatically Augmented Baghouse

\section{BAGHOUSE EFFICIENCY MODELING}

\section{Pulse-Jet}

Sixteen vendors recommended the use of a pulse-jet baghouse with polyester felt bags--plain or Teflon coated. The other respondent recommended a shaker baghouse. Few data were available on the fractional efficiency of either type of baghouse. The Fabric Filter Manual (FFM) (1983) notes that unless such data were obtained over a period of operation, including the various stages of filter performance, the data would not be useful. The FFM further states that without pilot testing, the prediction of fractional efficiency has no practical 
significance because the factors such as dust load, fabric type, fabric area, cleaning mechanism, cleaning frequency, and dust characteristics can vary greatly between applications. Nevertheless, an attempt will be made to evaluate baghouse performance for this cost analysis; however, a fair amount of uncertainty exists about the results. We will consider the pulse-jet baghouse first.

Particle penetration data for various fabric types measured under comparable experimental conditions were unavailable. The manufacturer of coated felt bags furnished measurements of the particle penetration of mixed lead oxide and granite dust as a function of Feret's diameter(a) at a face velocity of $10 \mathrm{ft} / \mathrm{min}$ while being pulse cleaned at $1-m i n$ intervals. Fractional penetrations for Feret's diameters of 0.12 to $84.2 \mu \mathrm{m}$ were reported for unconditioned bags (no previous dust loading) and conditioned bags. These data were plotted and values obtained for the sizes of interest are shown in Table C.I. Note that the higher efficiency for the conditioned fabric results because a dust cake was built-up.

TABLE C.1. Fractional Efficiency Data for Teflon ${ }^{\circledR}$ Coated Felt Bags

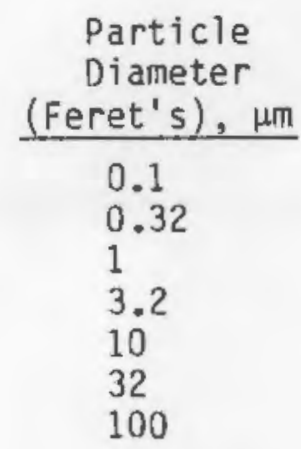

* Extrapolated
Teflon ${ }^{\circledast}$-Coated Bags, $10 \mathrm{ft} / \mathrm{min}$ Superficial Velocity Unconditioned Conditioned

$\begin{array}{ll}0.944^{*} & 0.99540 * \\ 0.9715 & 0.99690 \\ 0.9959 & 0.999690 \\ 0.99994 & 0.999960 \\ 0.99996 \text { * } & 0.99999 * \\ 0.99999 * & 0.9999{ }^{*} \\ 0.99999 * & 0.99999 *\end{array}$

(a) Feret's diameter is defined as the distance between two tangents on opposite sides of the particle and perpendicular to the botton of the microscope field (Feret 1931). Particle size measurements using this technique are not directly comparable to the more desirable aerodynamic equivalent diameter, which is the diameter of a sphere of water that would fall at a velocity equal to the actual particle. 
Similar fractional efficiency data for standard polyester felt in a pulsejet baghouse are lacking. Data were found, however, for both the uncoated and coated felt bags that had been obtained using a particle seepage approach. Recent work by Leith and Ellenbecker (1983) postulates that pulse-jet baghouse emissions result from gradual particle seepage through the bags caused by the snapping action of the fabric when cleaned. Thus, no immediate linkage appears between upstream and downstream aerosol characteristics. Particle seepage would vary as a function of particle size, mass of dust per unit area of fabric, the time between cleaning pulses, the fabric dynamics during cleaning, and the fabric characteristics.

Flux (aerosol mass per unit fabric area per time) was measured as a function of particle diameter (Feret's) for fly ash, granite, and limestone dusts using a three-bag baghouse. Singed, Teflon-coated, and plain polyester felt bags were conditioned with dust for $20 \mathrm{hr}$ with continuous pulse cleaning at 1-min intervals. The three superficial filtration velocities (flow rate/cloth area) used were 50,75 , and $100 \mathrm{~mm} / \mathrm{s}(10,15$, and $20 \mathrm{ft} / \mathrm{min})$. The data used in this cost study (Table C.2) were taken from a plot of flux versus particle size with bag type as a parameter. The flux data had been averaged for the three dusts and superficial filtration velocities. The flux units used were mass per unit fabric area per time.

\section{TABLE C.2. Unit Flux by Particle Size}

\begin{tabular}{|c|c|c|}
\hline $\begin{array}{l}\text { Particle } \\
\text { Diameter }\end{array}$ & Flux, & $n^{-2} s^{-1}$ \\
\hline$\left(\right.$ Feret $\left.^{\prime} s\right), \mu m$ & Teflon ${ }^{\Theta}$-coated & Plain \\
\hline 0.1 & $1.5 \times 10^{-12}$ & $5.0 \times 10^{-12}$ \\
\hline 0.32 & $2.0 \times 10^{-11}$ & $1.9 \times 10^{-10}$ \\
\hline 1.0 & $2.0 \times 10^{-10}$ & $2.0 \times 10^{-9}$ \\
\hline 3.2 & $6.0 \times 10^{-10}$ & $1.0 \times 10^{-8}$ \\
\hline 10 & $6.0 \times 10^{-10}$ & $1.0 \times 10^{-8}$ \\
\hline 32 & $1.1 \times 10^{-10_{\star}}$ & $4.0 \times 10^{-9} \star$ \\
\hline 100 & $1.0 \times 10^{-12 *}$ & $1.9 \times 10^{-10_{*}}$ \\
\hline
\end{tabular}


To scale these experimental results to the firing range case and to be consistent with the experiment, a l-min interval between cleaning pulses was assumed. At the firing range, the bulk of the dust load is generated by the intermittent test firings. Unlike the experimental conditions where cleaning was continuous and ontine, the demand for bag cleaning in this case will probably be intermittent and may not need to be online.

online cleaning relies on the agglomeration of particles in a dust cake on the fabric. The agglomerated particles, when pulsed off the fabric, fall through what is typically rising air to the hopper or at least to a point lower on the bag. When the dust cake particles do not agglomerate, some vendors recommend taking the baghouse or a compartment offline during cleaning so there is no airflow to inhibit particle settling. Other vendors recommend that dirty air enter the baghouse near the top and flow downard. Offline cleaning may reduce emissions to the level typical of a shaker baghouse, which requires offline cleaning. To simulate the worst case, we assumed that the cleaning will be online.

According to the seepage theory, more frequent cleaning results in higher emissions if other factors are equal. How much cleaning will be required at the firing range is an impossible question to answer without pilot testing. Some common strategies to automate intermittent online cleaning are

1. cleaning pulses set to occur at regular intervals between manual ON and OFF commands

2. a preset number of cleaning pulses to be initiated by a manual ON command

3. a preset number of pulses to be initiated by a differential baghouse pressure switch.

Strategies 1 and 2 can be used anytime (e.g., daily, weekly, after hours, or after every shot). Some manufacturers were of the opinion that the predicted dust loading was very light and cleaning would not be needed after every shot. Strategy 3 would probably result in the least frequent cleaning. Given a constant airflow, the buildup of dust per unit fabric area and hence baghouse differential pressure, are proportional to the amount of aerosol generated and inversely proportional to the cloth area. Also, particle flux is directly proportional to cloth area and the frequency of clearing pulses; therefore, under 
Strategy 3 , the combined cloth area effects may cancel and be unimportant to overall emissions. Strategy 3 is the online cleaning method we recomend, but we cannot predict the amount of cleaning required and hence the emissions with any confidence. We assumed that for the worst case, cleaning will be started when every round is fired and cease at the end of the clearance time. This is shown to maximize emissions and will penalize baghouses with greater fabric area.

Because the unit flux by particle size is fixed for each fabric, the particle size distribution is fixed with a somewhat larger mass mean size for plain felt than for the coated felt. Leith and Ellenbecker (1983) showed that the particle size with maximum flux was about 1 wm for the Teflon-coated felt and $8 \mu \mathrm{m}$ for the plain felt, and that the maximum flux was about three orders of magnitude higher for the plain felt than for the coated.

The FILTER model (see Appendix A) was adapted to use the flux data in Table C.2 to make a new version, FILTER.BAG. The flux for each size bracket was determined by multiplying each flux value by the cloth area and the length of cleaning time expressed as pulses (1 pulse/60 s).

$$
\text { Flux,g }=\underset{\text { Flux }}{\text { Particle }} \frac{\mathrm{kg}}{\mathrm{m}^{2} \mathrm{~s}} \times \underset{\text { Area }}{\text { Cloth }} \mathrm{ft}^{2} \times \text { Pulses } \times \frac{1000 \mathrm{~g}}{\mathrm{~kg}} \times \frac{60 \mathrm{~s}}{\text { Pulse }} \times \frac{\mathrm{m}^{2}}{10.764 \mathrm{ft}^{2}}(\mathrm{C.l})
$$

Aerosol concentrations were examined that had been measured at 1 -min intervals at the exhaust point of a target bay during 10 test rounds. After 45 min, the amount of additional aerosol passing that point was insignificant; therefore, it was assumed that if a baghouse were in operation, it would not have been cleaning for longer than $45 \mathrm{~min}$. The test round fired was $3400 \mathrm{~g}$. The number of cleaning pulses is then estimated by the integer value of Equation $\mathrm{C.2}$.

$$
\text { Pulses }=\frac{\text { Projectile Weight, } g}{3400 \mathrm{~g}} \times 45
$$


After the number of pulses was calculated, the flux per particle size bracket was calculated using Equation (C.I). The dust collected by the baghouse is calculated by summing the fluxes and subtracting from the input aerosol mass. The calculation of operating cost for the after filters proceeds as described in Appendix $A$ with the flux per bracket as the input size distribution.

System filtration efficiencies exceeded the criterion given in Table 1 in all cases. A brief summary of baghouse efficiency, system efficiency, downstream disposable (after-filter) cost, and after-filter bank changes is shown in Table C.3 for comparison with the results using the fractional efficiency data for coated felt. (The efficiency value of 1.0 is interpreted not as 1.0 , but as exceeding the value that could be expressed within allowed significant digits.) The estimates, when expressed as penetrations, are probably oniy accurate to one or two orders of magnitude. Because the after-filter costs predicted with the fractional efficiency method were intermediate to afterfilter costs predicted with the flux method, the data from the flux method will be used in this cost study as representative of extremes. This will also allow us to consider the economic merits of two types of fabric.

\section{$\underline{\text { SHAKER }}$}

The only data found on the fractional efficiency of a shaker baghouse were obtained at an Electric Power Research Institute pilot plant for studying the application of air cleaning devices at coal-fired generating stations (Smith, Cushing and Carr 1981). Particle sizing was performed using an electrical mobility analyzer and a cascade impactor, so the size data are considered to be aerodynamic size. The particles sampled in their study were fly ash. The data are listed in Table C.4. The lowest efficiency in their study was for particles in the range of 7 to $8 \mu \mathrm{m}$. The authors also noted that during and after shaking, the emission of the fraction around 1 to $2 \mu \mathrm{m}$ increased considerably. This disappeared after the dust cake had reestablished itself. It is not known if cleaning cycles were included in the experimental time interval.

Calculations using FILTER showed an overall shaker efficiency of about 0.99984 , for Size Distribution No. 3 (see Table 5 in main text), which was slightly better than the best resuits for the pulse-jet shown in Table C.3. 
TABLE C.3. Summary of Baghouse Performance Results

Fractiona 1

Efficiency Method

Baghouse Efficiency

Coated Felt

$\frac{\text { Flux Method }}{\text { Coated Felt Plain Felt }}$

Minimum

0.998

Maximum

0.998

0.9991

0.985

0.9997

0.995

System Efficiency

Minimum

Maximum

0.999997

0.9999995

0.99999998

1.0

0.9999998

0.999999998

After-Filter Cost, \$K

Minimum

13

19

Average

Maximum

25

1.7

3.1

28

5.6

51

93

After-Filter Bank Changes

Minimum

Maximum

6

6

1.5

34

2128

IABLE C.4. Shaker and Electrostatic Baghouse Filtering Efficiency

\begin{tabular}{|c|c|c|}
\hline Particle & \multicolumn{2}{|c|}{ Filtering Efficiency } \\
\hline Oiameter, um & Shaker & Electrostatic \\
\hline $\begin{array}{l}0.1 \\
0.32 \\
1.0 \\
3.2 \\
10.0 \\
32.0 \\
100.0\end{array}$ & $\begin{array}{l}0.999985^{\star} \\
0.999985 \\
0.999937 \\
0.99957 \\
0.99925 \\
0.9999 \\
0.999987^{\star}\end{array}$ & $\begin{array}{l}0.994^{\star} \\
0.99955 \\
0.999963 \\
0.999988 \\
0.999977 \\
0.9999957 \star \\
0.9999992^{\star}\end{array}$ \\
\hline $\begin{array}{l}\text { Baghouse Efficiency, } \\
\text { Size Distribution } \\
\text { No. } 3\end{array}$ & 0.99984 & 0.9981 \\
\hline $\begin{array}{l}\text { Maximum Unit } \\
\text { Pressure Drop, } \\
\text { in. WG }\end{array}$ & 2.0 & 6.0 \\
\hline
\end{tabular}

* Indicates value extrapolated beyond data. 
There is some uncertainty whether the fractional efficiency would be as good at the firing range where the pressure pulses could disturb the dust cake. The cost estimates for the shaker were made using this data and the lesser efficiency of the conditioned coated felt listed in Table C.1 for comparison.

\section{Electrostatically Enhanced Baghouse}

The efficiency data for the electrostatically enhanced baghouse were obtained from Felix and McCain (1979) and are listed in Table C.4. The particle size data were aerodynamic size as obtained from cascade impactor samples. The baghouse collection efficiency calculated with FILTER, 0.9981 , was better than that for a standard baghouse with the plain felt fabric (Table C.3).

\section{COST ESTIMATING}

Tables C.5a and C.5b sumarize the descriptive information about the baghouses considered. Included are the shape--cylindrical or box--and whether a high pressure design was used ( $H i \mathrm{P}$ ); the type of access for changing bags [walk-in above tube sheet (TI) and on side wall (SI), hatch located above tube sheet (TH) and in side wall (SH)]; bag length; number of bags; area of cloth; cubic feet of cloth assuming a $1 / 8 \mathrm{in}$. thickness and no compaction; wall thickness of the casing; the vendor's estimate of compressed air required for cleaning; horsepower of compressor to supply the required air; and the number of solenoid and diaphragm valve pairs in the cleaning system. The tables also show the average, maxima, and minima of most parameters.

Tables C.6a and C.6b summarize the initial investment costs to acquire the baghouses including the vendor-supplied baghouse cost and our estimates of erection and compressor costs. (Note that from here on the tables will differ in format because of the different computational needs for the equipment.) Table C.6a also includes the power cost of operating the compressor for 20 years assuming it would operate $20 \%$ of the time. Averages, minima, and maxima are indicated for each parameter. The erection (installation) costs were estimated as shown in Table C.7. 
TABLE C.5a. Descriptive Summary of Pulse-Jet Baghouses

\begin{tabular}{|c|c|c|c|c|c|c|c|c|c|c|c|}
\hline Maker & \multicolumn{2}{|c|}{ Type } & $\begin{array}{c}\text { Bag } \\
\text { Access }\end{array}$ & $\begin{array}{c}8 \mathrm{ag} \\
\text { Length, } \\
\mathrm{ft}\end{array}$ & $\begin{array}{c}\text { Number } \\
\text { 8ags }\end{array}$ & $\begin{array}{l}\text { Cloth, } \\
\mathrm{ft}^{2} \\
\end{array}$ & $\begin{array}{l}\text { Cloth } \\
\mathrm{ft}^{3}, \\
\end{array}$ & $\begin{array}{c}\text { Hall } \\
\text { Thickness, } \\
\text { in. } \\
\end{array}$ & $\begin{array}{l}\text { Compress } \\
\text { Ai } r \text { acfin } \\
\text { at inopsi }\end{array}$ & hp & $\begin{array}{c}\text { No. } \\
\text { Valves }\end{array}$ \\
\hline M & & Box & TI & 12 & 196 & 3077 & 32 & 0.134 & 30 & 7 & 14 \\
\hline D & & $80 x$ & $\mathrm{TH}$ & 12 & 172 & 3236 & 34 & 0.105 & 12 & 5 & 32 \\
\hline $\mathbf{R}$ & & Cyl & TI & 12 & 162 & 3890 & 40 & 0.135 & 0 & 15 & 0 \\
\hline U & & Box & $\mathrm{TH}$ & 8 & 280 & 3520 & 37 & 0.188 & 8 & 3 & 8 \\
\hline E & & Cyl & TH & 12 & 202 & 3810 & 40 & 0.134 & 61 & 20 & 16 \\
\hline$\vec{T}$ & & Box & SH & 6.5 & 308 & 2400 & 25 & 0.134 & 42 & 10 & 12 \\
\hline $\mathrm{R}$ & & $80 x$ & TI & 12 & 182 & 3380 & 35 & 0.135 & 50 & 20 & 13 \\
\hline 0 & $\mathrm{Hi} P$ & Cyl & TI & 10 & 198 & 3114 & 32 & 0.188 & 45 & 10 & 36 \\
\hline M & $\mathrm{Hi} \mathrm{P}$ & Cyl & TI & 12 & 200 & 3120 & 32 & 0.25 & 42 & 10 & 14 \\
\hline $\mathrm{HH}$ & $\mathrm{Hi} P$ & $\mathrm{Cy} 1$ & TI & 10 & 228 & 3692 & 38 & 60 & 20 & 24 & \\
\hline$z$ & & Box & TI & 10 & 340 & 4000 & 42 & 0.105 & 62 & 20 & 20 \\
\hline $\bar{x}$ & & Box & TH & 12 & 325 & 6125 & 64 & 0.1046 & 78 & 20 & 25 \\
\hline $\mathbf{N}$ & & Box & $T I$ & 9 & 336 & 4939 & 51 & 0.105 & 66 & 20 & 24 \\
\hline H & & Box & TI & 20 & 160 & 5031 & 52 & 0.25 & 30 & 7 & 10 \\
\hline CC & & $80 x$ & $T 1$ & 14 & 224 & 4928 & 51 & 0.188 & 50 & 20 & 16 \\
\hline GG & & Box & TI & 8 & 400 & 6250 & 65 & 0.105 & 40 & 10 & 25 \\
\hline $\mathrm{FF}$ & & $80 x$ & SI & 8 & 280 & 6000 & 62 & 0.105 & 5 & 3 & 36 \\
\hline$v$ & $\mathrm{Hi} P$ & Box & TI & 10 & 294 & 4000 & 42 & 0.38 & 71 & 20 & 21 \\
\hline $\mathrm{JJ}$ & $\mathrm{Hi} \mathrm{P}$ & $80 x$ & $\mathrm{TI}$ & 8 & 438 & 5500 & 57 & 0.25 & 70 & 20 & 25 \\
\hline $\mathrm{FF}$ & & Box & SI & 8 & 360 & 8000 & B3 & 0.105 & 5 & 3 & 48 \\
\hline Aver & & & & & 264 & 4401 & 46 & 0.1550 & 41 & 13 & 21 \\
\hline & & & & & 160 & 2400 & 24.96 & 0.0000 & 0 & 3 & 0 \\
\hline Maxime & & & & & 438 & 8000 & 83.2 & 0.3800 & 78 & 20 & 48 \\
\hline
\end{tabular}

Note: $C y l=c y l$ inder, Hi $P=$ high pressure

TABLE C.5b. Descriptive Summary of Shaker and Electrostatically Enhanced Baghouses

\begin{tabular}{|c|c|c|c|c|c|c|c|c|c|}
\hline Device & $\begin{array}{l}\text { Media } \\
\text { Access }\end{array}$ & $\begin{array}{l}\text { Rag } \\
\text { Length, } \\
\text { ftt } \\
\end{array}$ & $\begin{array}{l}\text { Number } \\
\text { Media } \\
\text { Untis }\end{array}$ & $\begin{array}{l}\text { Media, } \\
\mathrm{ft}^{2}\end{array}$ & $\begin{array}{c}\text { Compressed } \\
\text { Mejdia, } \\
\mathrm{ft}^{3} / \mathrm{set} \\
\end{array}$ & $\begin{array}{c}\text { Wall } \\
\text { Thickness, } \\
\text { in. }\end{array}$ & $\begin{array}{c}\text { nust } \\
\text { to) liopper } \\
\text { Per.Shot, } 9\end{array}$ & $\begin{array}{l}\text { Pun } \\
\text { Fraction, } \\
\text { hr/hr. } \\
\end{array}$ & $\begin{array}{l}\text { Auxiliary } \\
\text { Equipunent, } \\
\text { hp }\end{array}$ \\
\hline $\begin{array}{l}\text { Standard Shaker } \\
\text { Shaker With Coated Bags } \\
\text { Clectrostatic Nugmented }\end{array}$ & $\begin{array}{l}\text { SI } \\
\text { SI } \\
\text { SI }\end{array}$ & $\begin{array}{r}7 \\
7 \\
12\end{array}$ & $\begin{array}{l}960 \\
960 \\
110\end{array}$ & $\begin{array}{l}8392 \\
8392 \\
2750\end{array}$ & $\begin{array}{l}87 \\
81 \\
29\end{array}$ & $\begin{array}{l}0.0747 \\
0.0747 \\
0.188\end{array}$ & $\begin{array}{l}4900 \\
4900 \\
4900\end{array}$ & $\begin{array}{r}0 \\
0 \\
0.5\end{array}$ & $\begin{array}{l}0 \\
0 \\
5\end{array}$ \\
\hline
\end{tabular}

The first costs for the shaker are not as first supplied by the vendor. The vendor's baghouse estimate was $\$ 33 \mathrm{~K}$, but without the extra strength required for this application and without the hopper valves needed for each of the twelve compartments. An additional $\$ 1 \mathrm{~K}$ was added per valve and $\$ 20 \mathrm{~K}$ for the stronger construction giving a total of $\$ 65 \mathrm{~K}$. For the shaker with coated media, another $\$ 33 \mathrm{~K}$ was added to cover the cost of the 960 coated bags. For the other baghouses, we frequently had to add our own estimates for accessory items such as the hopper valves. 
IABLE C.6a. Pulse-Jet Baghouse First Costs, Excluding Fan

\begin{tabular}{|c|c|c|c|c|}
\hline Maker & $\begin{array}{c}\text { Baghouse } \\
\text { w/bags, } \\
\$ K\end{array}$ & $\begin{array}{c}\text { Compressor, } \\
\$ K\end{array}$ & $\begin{array}{l}\text { Erection } \\
\text { Pad, Duct } \\
\text { etc., \$K }\end{array}$ & $\begin{array}{c}\text { Subtotal, } \\
\text { \$K }\end{array}$ \\
\hline$M$ & 33 & 9.9 & 61.3 & 104 \\
\hline$D$ & 33 & 5.6 & 61.3 & 100 \\
\hline$R$ & 58 & 0 & 58.5 & 116 \\
\hline U & 35 & 5.5 & 61.3 & 102 \\
\hline$E$ & 42 & 14.8 & 61.3 & 119 \\
\hline$T$ & 36 & 10 & 61.3 & 107 \\
\hline$R$ & 54 & 14.8 & 61.3 & 131 \\
\hline Q & 69 & 10 & 61.3 & 140 \\
\hline$M$ & 85 & 10 & 61.3 & 156 \\
\hline $\mathrm{HH}$ & 70 & 14.8 & 61.3 & 146 \\
\hline$z$ & 41 & 14.8 & 61.3 & 117 \\
\hline$x$ & 43 & 14.8 & 61.3 & 119 \\
\hline N & 58 & 14.8 & 61.3 & 134 \\
\hline $\mathrm{H}$ & 110 & 9.9 & 61.3 & 181 \\
\hline$C C$ & 100 & 14.8 & 61.3 & 176 \\
\hline $\mathrm{GG}$ & 80 & 10 & 61.3 & 151 \\
\hline $\mathrm{FF}$ & 55 & 5.5 & 61.3 & 122 \\
\hline$v$ & 165 & 14.8 & 61.3 & 241 \\
\hline $\mathrm{JJ}$ & 115 & 14.8 & 61.3 & 191 \\
\hline FF & 65 & 5.5 & 61.3 & 132 \\
\hline Average & 67.35 & 10.76 & 61.16 & 139.27 \\
\hline Mi nimum & 33.00 & 0.00 & 58.50 & 99.90 \\
\hline Maximum & 165.00 & 14.80 & 61.30 & 241.10 \\
\hline
\end{tabular}

TABLE C.6b. Shaker and Electrostatically Augmented Baghouse First costs, Excluding Fan

\begin{tabular}{lccccc}
\multicolumn{1}{c}{ Device } & $\begin{array}{c}\text { Unit, } \\
\text { \$K }\end{array}$ & $\begin{array}{c}\text { Auxiliary } \\
\text { Equipment, } \\
\text { \$K }\end{array}$ & $\begin{array}{c}\text { Erection } \\
\text { Pad, Duct } \\
\text { etc., \$K }\end{array}$ & $\begin{array}{c}\text { Special } \\
\text { Installation, } \\
\$ K\end{array}$ & $\begin{array}{c}\text { Subtotal, } \\
\text { \$K }\end{array}$ \\
\cline { 1 - 2 } Standard Shaker & 65 & 0 & 58.5 & 0 & 123.50 \\
Shaker With Coated Bags & 88 & 0 & 58.5 & 0 & 146.50 \\
Electrostatic Augmented & 83 & 5.6 & 61.3 & 0 & 149.90
\end{tabular}


IABLE C.7. Installation Costs For Baghouses

\begin{tabular}{|c|c|c|}
\hline Item & $\begin{array}{c}\text { Electrostatically } \\
\text { Enhanced and } \\
\text { Pulse-Jet, } \$ \\
\end{array}$ & Shaker, $\$$ \\
\hline $\begin{array}{l}\text { Pad } 22 \times 30 \mathrm{ft} \\
\text { Compressor Shelter } \\
\text { Hopper shed } \\
7 \text {-gauge stainless stee } 1\end{array}$ & $\begin{array}{l}4700 \\
2800 \\
5300\end{array}$ & $\begin{array}{l}4700 \\
2800 \\
5300\end{array}$ \\
\hline $\begin{array}{l}\text {-gauge stainless steel } \\
\text { ducts plus erection }\end{array}$ & 20900 & 20900 \\
\hline Electrical & 6400 & 6400 \\
\hline Freight & 1200 & 1200 \\
\hline Pressure test & 1900 & 1900 \\
\hline Drum scale & 8100 & 8100 \\
\hline Flow controls & 10000 & 10000 \\
\hline Total & $\$ 61300$ & $\$ 58500$ \\
\hline
\end{tabular}

Tables C.8a and C.8b show the estimates for maintenance costs for 20 years of operation in terms of current dollars. The basic cost and operating assumptions were those 1 isted in pages 12-23 in the main report. For all 20 of the pulse-jet baghouses, the maintenance costs were computed for both standard and coated polyester felts. Most vendors seemed to feel that the standard felt bag life would be considerably longer than in applications where dust loads are heavy and cleaning continuous; therefore, they estimated about a 2-year bag life. The 2-year bag life translates into a requirement for purchasing nine replacement sets of bags and installing, changing, and disposing of 10 sets during the 20-year anticipated life. The maker of the coated felt claimed a substantially longer bag $1 \mathrm{ife}$ and a lower pressure drop than that for standard. For this study, that claim was tempered with skepticism and a 2.25-year bag life was assumed. Therefore, eight sets will be handled during facility life and seven replacement sets will be purchased. The bag life for the electrostatic baghouse was assumed to be the same as the standard feit, 2 years. The manufacturer of the shaker baghouse claimed a bag life of 10 years; a 5-year value was used for this study resulting in installation and disposal of four sets of bags and procurement of three sets. In Table 0.8 maintenance costs include the cost of replacement bags, bag installation and disposal, collected dust disposal, equipment repairs, and operation. 
TABLE C.8a. Twenty-Year Maintenance Costs for Pulse-Jet Baghouses

\begin{tabular}{|c|c|c|c|c|c|c|c|c|}
\hline Maker & $\begin{array}{l}\text { Man-hr } \\
\text { Per Bag } \\
\text { Change }\end{array}$ & $\begin{array}{l}\text { Ten Changes } \\
\text { Standard Bag } \\
\text { Labor, \$K. }\end{array}$ & $\begin{array}{c}\text { Standard Bag } \\
\text { Disposal, } \\
\$ \mathrm{~K} / 20 \text { y } \\
\end{array}$ & $\begin{array}{c}\text { Eight Changes } \\
\text { Coated Bay } \\
\text { Labor, \$K } \\
\end{array}$ & $\begin{array}{l}\text { Coated Bag } \\
\text { Disposal, } \\
\$ K / 20 \text { yr } \\
\end{array}$ & $\begin{array}{l}\text { Must } \\
\text { Disposal, } \\
\$ K / 6000 \\
\text { shots } \\
\end{array}$ & $\begin{array}{l}\text { Repair } \\
\text { Codes } \\
\text { C P A E B }\end{array}$ & $\begin{array}{c}\text { Misc. } \\
\text { Repairs, } \\
\$ k \\
\end{array}$ \\
\hline M & 98 & 30.38 & 8.25 & 24.30 & 6.60 & 24.08 & 1111 & 22.30 \\
\hline D & 86 & 26.66 & 8.64 & 21.33 & 6.91 & 24.08 & 1111 & 28.50 \\
\hline$R$ & 81 & 25.11 & 10.32 & 20.09 & 8.26 & 24.08 & 111 & 12.54 \\
\hline U & 140 & 43.40 & 9.51 & 34.72 & 7.61 & 24.08 & $\begin{array}{llll}1 & 1 & 1 & 1\end{array}$ & 20.24 \\
\hline $\mathbf{E}$ & 101 & 31.31 & 10.17 & 25.05 & 8.13 & 24.08 & $\begin{array}{llll}1 & 1 & 1 & 1\end{array}$ & 22.99 \\
\hline$T$ & 154 & 47.74 & 6.64 & 38.19 & 5.31 & 24.08 & $\begin{array}{llll}1 & 1 & 1 & 1\end{array}$ & 21.62 \\
\hline $\mathrm{R}$ & 91 & 28.21 & 9.02 & 22.57 & 7.22 & 24.08 & 1111 & 21.96 \\
\hline$Q$ & 99 & 30.69 & 8.35 & 24.55 & 6.68 & 24.08 & 1111 & 29.87 \\
\hline$M$ & 100 & 31.00 & 8.37 & 24.80 & 6.70 & 24.08 & $\begin{array}{llll}1 & 1 & 1 & 1\end{array}$ & 22.30 \\
\hline $\mathrm{HH}$ & 114 & 35.34 & 9.89 & 28.27 & 7.91 & 24.08 & $\begin{array}{llll}1 & 1 & 1 & 1\end{array}$ & 25.74 \\
\hline$Z$ & 170 & 52.70 & 10.84 & 42.16 & 8.67 & 24.08 & $\begin{array}{llll}1 & 1 & 1 & 1\end{array}$ & 24.37 \\
\hline$x$ & 163 & 50.38 & 16.34 & 40.30 & 13.08 & 24.08 & $\begin{array}{llll}1 & 1 & 1 & 1\end{array}$ & 26.09 \\
\hline$N$ & 168 & 52.08 & 13.28 & 41.66 & 10.62 & 24.08 & $\begin{array}{llll}1 & 1 & 1 & 1\end{array}$ & 25.74 \\
\hline H & 80 & 24.80 & 13.29 & 19.84 & 10.63 & 24.08 & $\begin{array}{llll}1 & 1 & 1 & 1\end{array}$ & 20.93 \\
\hline $\mathrm{CC}$ & 112 & 34.72 & 13.10 & 27.78 & 10.48 & 24.08 & $\begin{array}{lll}1 & 1 & 1\end{array}$ & 22.99 \\
\hline GG & 200 & 62.00 & 16.77 & 49.60 & 13.41 & 24.08 & $\begin{array}{llll}1 & 1 & 1 & 1\end{array}$ & 26.09 \\
\hline FF & 140 & 43.40 & 15.96 & 34.72 & 12.77 & 24.08 & $\begin{array}{llll}1 & 1 & 1 & 1\end{array}$ & 29.87 \\
\hline$v$ & 147 & 45.57 & 10.78 & 36.46 & 8.62 & 24.08 & 1111 & 24.71 \\
\hline $\mathrm{JJ}$ & 219 & 67.89 & 14.87 & 54.31 & 11.89 & 24.08 & 1111 & 26.09 \\
\hline $\mathrm{FF}$ & 180 & 55.80 & 21.27 & 44.64 & 17.01 & 24.08 & $\begin{array}{llll}1 & 1 & 1 & 1\end{array}$ & 34.00 \\
\hline Averag & e 132.13 & 40.96 & 11.78 & 32.77 & 9.43 & 24.08 & & 24.45 \\
\hline Minimus & 80.00 & 24.80 & 6.64 & 19.84 & 5.31 & 24.08 & & 12.54 \\
\hline Maximur & m 219.00 & 67.89 & 21.27 & 54.31 & 17.01 & 24.08 & & 34.00 \\
\hline
\end{tabular}

Repair Code Key

C - annual compressor maintenance

P - semi-annual pulse valve rebuilds

A - annual miscellaneous maintenance

$E$ - one time replacement of cleaning cycle control electronics

$B$ - one time bearing and other repair of blower

A "1" under the repair code column indicates that the repair is applicable to the device

and is accounted for in the cost estimate. 
TABLE C.8a. (contd)

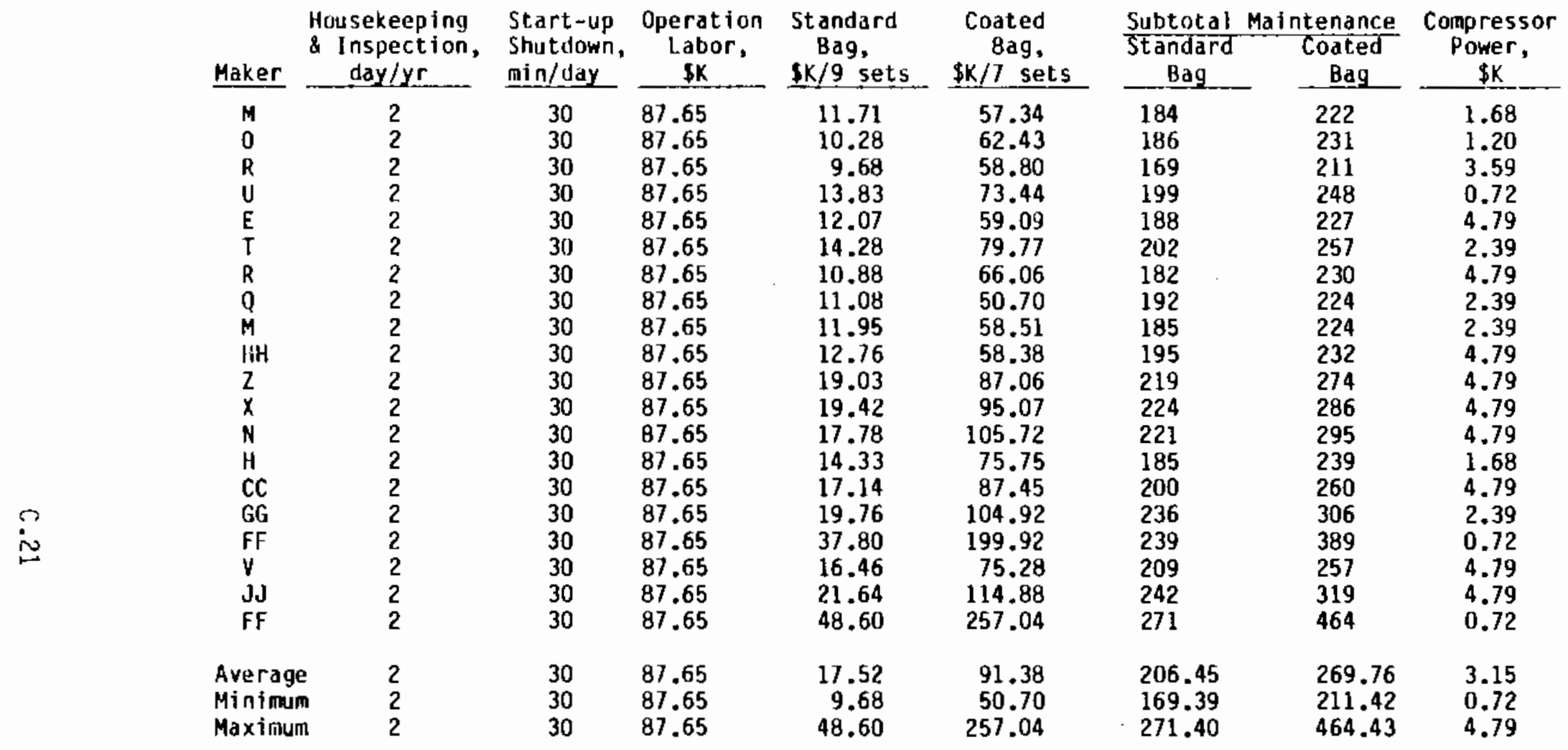


TABLE C.8b. Twenty-Year Maintenance Costs for Shaker and Electrostatically Augmented Baghouses

\begin{tabular}{|c|c|c|c|c|c|c|c|c|c|c|c|c|c|}
\hline Device & $\begin{array}{l}\text { Replacement } \\
\text { sodia, } \\
\text { sots/20 rr }\end{array}$ & $\begin{array}{l}\text { Modto } \\
\text { Repl acement, } \\
\text { Ex/20 Yr }\end{array}$ & $\begin{array}{l}\text { Mun-hr } \\
\text { Per Mdla } \\
\text { Change }\end{array}$ & $\begin{array}{l}\text { Modis } \\
\text { Change } \\
\text { Labor, sx }\end{array}$ & $\begin{array}{c}\text { oldo } \\
01 \text { sposal, } \\
\text { SK/20 } x .\end{array}$ & $\begin{array}{l}\text { Olsposal, } \\
\text { sk/6000 } \\
\text { Shots } \\
\end{array}$ & $\begin{array}{l}\text { Repalr } \\
\text { Codes } \\
\text { CPAE E }\end{array}$ & $\begin{array}{c}\text { Mlsc, } \\
\text { Repalrs, } \\
\text { Sx }\end{array}$ & $\begin{array}{l}\text { Housekeop Ing } \\
\text { Inspection, } \\
\text { days/yr }\end{array}$ & $\begin{array}{l}\text { Start-up } \\
\text { Shutdown, } \\
\text { m] n/dax }\end{array}$ & $\begin{array}{c}\text { Operation } \\
\text { Labor. } \\
4\end{array}$ & $\begin{array}{c}\text { Subtotal } \\
\text { Wuintenance. } \\
\end{array}$ & $\begin{array}{c}\text { Auxillary } \\
\text { Power. } \\
\mathbf{S x}\end{array}$ \\
\hline Standard Shaker & 5 & 47.86 & 480 & 89.26 & 13.79 & 24,00 & 11 & 10.54 & 3 & 30 & 92.61 & 278,17 & 0.00 \\
\hline Shaker With Conted Bags & 5 & 165.02 & 480 & 69.28 & 13,79 & 24.08 & 11 & 10.54 & 3 & 30 & 92.61 & 395.34 & $0, \infty$ \\
\hline Electrostatlc Augmonted & 9 & 3.91 & 55 & 17.05 & 1.39 & 24.08 & 1141 & 20.24 & 3 & 10 & 118.52 & 195.20 & 2.99 \\
\hline
\end{tabular}

Ropalr Code Key

C - annusl compressor malntanance

P - seml-annual pulso valve robullds

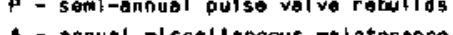

E -

exela control elactronics

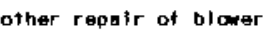

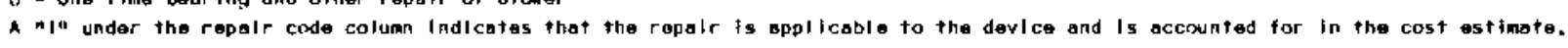


The labor to change a set of bags was based on an estimate of 0.5 man-hr per bag. The bag disposal cost was based on the uncompacted bag volume from Table $C .5$, the number of bag sets per 20 years, and the assumption that 240 bags could be packed into a drum per hour. (The vendors felt that while the bags could be compacted, they would probably return to their original size unless they were restrained. It was assumed here that the compactor would at least efficiently pack the rolled bags into a drum, leaving essentially no void space.) The 20-year cost of replacement bays was based on bag prices received from vendors for the standard and coated polyester felts, respectively. The methods for estimating repairs and operation costs was outlined in the body of the report. The repairs applicable to each device are indicated by a ' 1 ' under the appropriate repair code.

Table C.9 lists the 20-year cost of procuring, changing, and disposing of the disposable after-filters for each combination of after-filter bank, baghouse, and fabric type considered. For each baghouse, we give estimates for each of four practical combinations of after-filters; each after-filter type is denoted by the current bank that the type of filter occupies in the existing filter house. Thus, the 20-year cost of using the existing filters in series following the vendor $V$ baghouse is under the columns headed with bank combination ' $1,2,3$ ' for both the coated and standard polyester felts; namely, \$1.0K and $\$ 14.9 \mathrm{~K}$ respectively. (After-filter costs were calculated for baghouses with 1000 and $8000 \mathrm{ft}^{2}$ of cloth area using FILTER.BAG. The table entries are linear interpolations based on cloth area.) Also indicated are the averages for all after-filter combinations, all baghouses, and both fabric types. Notice that because of its greater collection efficiency, the cost of using after-filters is lower for the coated media than for the standard media by about $\$ 48 \mathrm{~K}$ in 20 years on the average. This cost advantage is of $\mathrm{fset}$ by the higher coated media cost as is shown in the next table.

Table C.9 also lists the number of times a filter bank will be changed in 20 years and the maximum operating pressure drop across the entire ventilation system. Vendors estimated that maximum pressure drops across the baghouses would range from 4 to $6 \mathrm{in.} W \mathrm{G}$ (i.e., the pressure at which the cleaning cycle 
TABLE C.9. Disposable Filter Usage for Pulse-Jet Baghouses

Disposable Filter Usage, \$K/20 yr

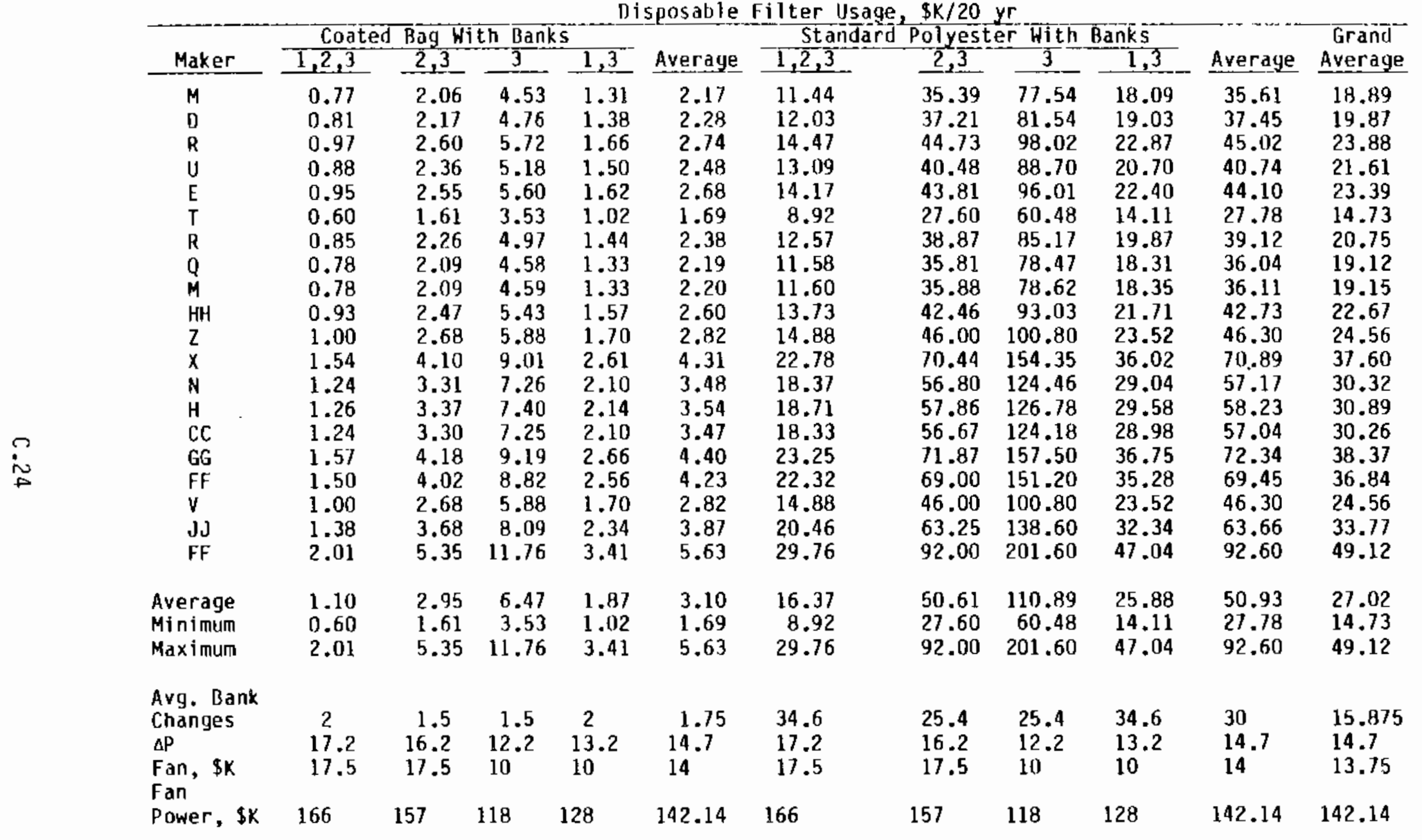


would probably be initiated and which would occur no oftener than once per shot). To be on the conservative side, 6 in. WG was used to add to the remainder of the system; however, a properly sized fabric area could probably be operated at a lower value. The assumed pressure drops for the rest of the system were $1,4,4$, and 2.2 for the first and second prefilters, HEPA filters, and structure, respectively. These filter pressure drops are the maxima at which change out is initiated, so the pressure estimate was made assuming each stage of filtration was at its fully loaded condition simultaneously. The maximum pressure drop was used to size the required fan, which cost is shown in the table. The $\$ 10 K$ cost of the fan in some configurations indicates that the existing fan was used with a larger motor. The cost of the fan for the selected configuration must be added to the first cost shown in Table C.7. The cost of the electricity to run the fan is also shown in Table C.9.

Table $C .10$ brings together all the costs for the pulse-jet baghouses listed on Tables C.5, C.6, C.8, and C.9. The table shows the total 20-year cost for each baghouse, fabric, and after-filter combination and their averages, maxima and minima, with power costs excluded. The power cost for the fan and average compressor capacity are given for the typical baghouse combination with each after-filter configuration and fabric type. The power cost is then added to the averages, maxima, and minima. Notice that the cost difference between using coated or standard polyester felt was at most $\$ 48 \mathrm{~K}$ or $11 \%$, which is probably less than the accuracy of the estimates. It may make little difference in cost which of these polyester felts is used. The difference would be in the subjective factor of how many times a filter bank must be changed-2 or 30 times on the average for the coated and standard felt, respectively. High-pressure baghouses were available with total costs both above and below the average. The variability between baghouses is partly due to the differences in first costs and partly due to the differences in fabric area. The latter source of variability occurs because the method used to calculate baghouse emissions (and hence cost of after-filters) is assumed to be a linear function of fabric area. This source of variability was only important in the case of the standard fabric, and in actual practice may not be important at all. 
TABLE C.10. Total Twenty-Year Cost for Pulse-Jet Baghouses

Pulse-Jet 8aghouse cost, $\$ K / 20$ yr

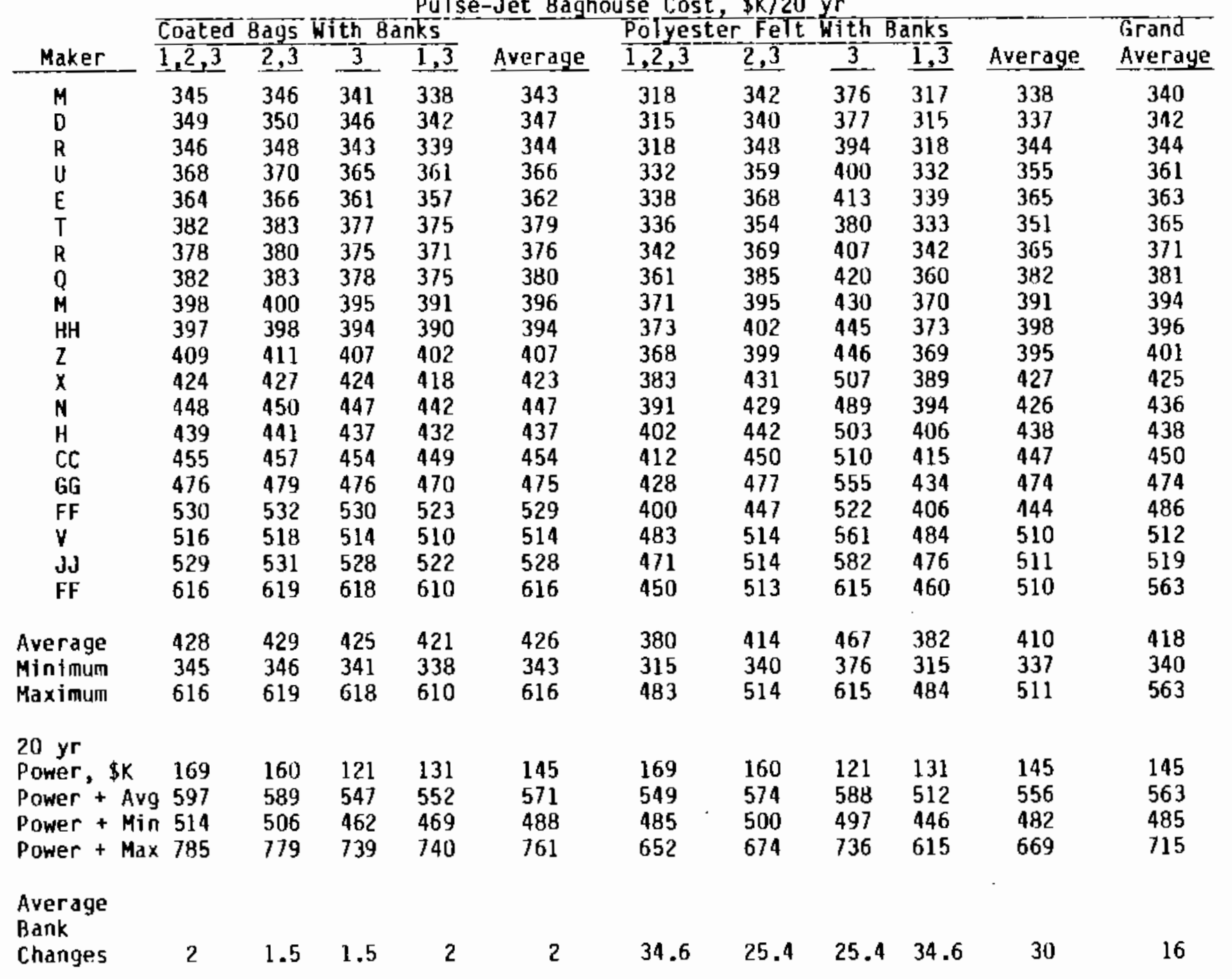


The shaker and electrostatic baghouse data shown in Table C.11 contain the disposable filter usage, number of times a filter bank must be changed, system efficiency, system total pressure drop, fan cost, total first cost (including fan) and fan power cost for 20 years of operation and for each combination of disposable filter banks. The table also summarizes with the totals for equipment and maintenance exclusive of power; total power cost; and total of equipment, maintenance, and power for the same combinations for 20 years. The replacement costs for disposable filters were calculated using FILTER. Note that the estimated total cost for the shaker generated using coated felt efficiency data was about $\$ 150 \mathrm{~K}$ more than when Felix and McCain's (1979) data were used.

RECOMMENDATION

To compare equipment types, a recommendation for the average costs of each type was made assuming the suitability of the existing filter housing for mounting the disposable filters. This was a tentative assumption pending structural analysis results.

For a pulse-jet baghouse with coated media, the configuration with banks 1 and 3 as after-filters resulted in the lowest cost exclusive of power. It would seem prudent to have some type of good prefilter ahead of the HEPA should the baghouse fail; however, a somewhat more efficient prefilter than the existing lst prefilter would be preferred. Thus, ignoring power cost, the best choice may be with banks 2 and 3 as after-filters at a slight extra cost of $\$ 9 \mathrm{~K}$ over 20 years. The same reasoning applied to the electrostatic and the shaker baghouses results in recomsnending the bank 2,3 after-filter configuration for those devices as well. Because of the pressure puise accompanying each test firing, it seems unlikely that a stable cake could be maintained on the shaker's woven fabric at the time most critical to filtration; therefore, it may be more reasonable to assume the operating cost to be better represented by the data generated with the coated media. 
TABLE C.11. Total Twenty-Year Cost for Shaker and Electrostatically Augmented Baghouse Costs

Shaker and Electrostatic Baghouse Costs, $\$ K / 20$ yr

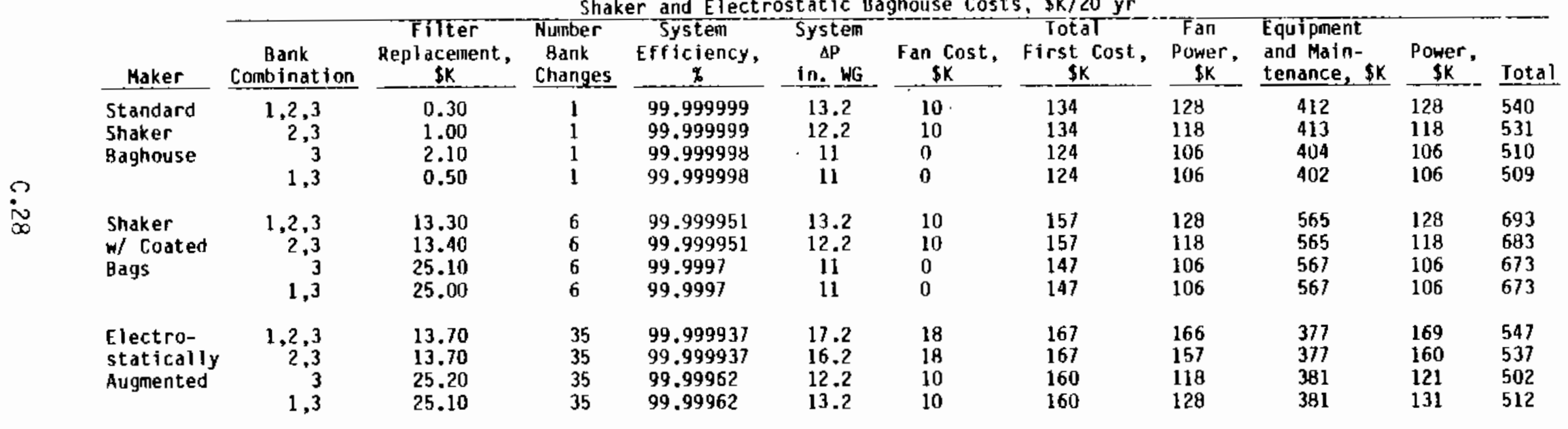




\section{REFERENCES}

Beachler, D. S., and J. A. Jahnke. 1981. APTI Course 413 Control of

Particulate Emissions Student Manual. EPA 450/2-80-066, Northrop Services, Inc., Research Triangle Park, North Carolina.

Felix, L. G., and J. D. McCain. 1979. Apitron Electrostatically Augmented Fabric Filter Evaluation. EPA 600/7-79-070, Southern Research Institute, Birmingham, Alabama.

Feret, L. R. 1931. "La Grosseurdes grains des matieres pulverisees," in Association International pour l'Essai des Materiaux, Congres de Zurich.

Leith, D., and M. J. Ellenbecker. 1983. Dust Emissions from a Pulse-Jet Fabric Filter, Filtration and Separation, July-August 1983, pp. 311-314.

McIlvaine Company. 1975. Fabric Filter Manual. The McIlvaine Co., Northbrook, Illinois.

Smith, W. B., K. M. Cushing and R. C. Carr. 1981. "Measurement Procedures and Supporting Research for Fabric Filters." In Proceedings of First Conference on Fabric Filter Technology for Coal-Fired Power Plants. CS-2238, Electric Power Research Institute, Palo Alto, California. 
- 
APPENDIX D

CARTRIDGE HOUSES 


\section{CARTRIDGE HOUSES}

A cartridge house collects particles on filter media made of a treated cellulose paper that is pleated and formed into a cylindrical cartridge. The cartridge is very similar in appearance to a truck carburetor air-cleaner. It is about $12 \mathrm{in}$. in diameter by $24 \mathrm{in}$. high. Figure $\mathrm{D} .1$ shows a typical cartridge house with several cartridges mounted below a tube sheet in a configuration similar to a pulse-jet baghouse. Dirty air enters near the bottom of the hopper and passes upward and through the cartridge to be exhausted at the top of the housing. Particles collected on the cartridges are removed by pulses of clean air directed through the cartridge in a direction opposite to the normal airflow. The removed particles that have agglomerated to a sufficiently large size settle into the hopper by gravity. Venturis between the compressed air nozzles and the cartridges amplify the cleaning airflow over the amount injected by the compressed air system.

In the standard configuration (Figure 0.1 ), the cartridges are accessed by opening a door on the dirty-air side of the housing. Various mechanisms are used for clamping the cartridges against the tube sheet to make an airtight seal. One type requires a person to partly enter the housing to unfasten a bolt at the bottom of each cartridge. Another type has a lever operated mechanism for clamping entire rows of cartridges simultaneously. The lever is mounted just inside the access door. When the cartridges are loosened, they can be slid off the ends of a pair of rails and placed in a plastic bag.

A second configuration has a walk-in plenum on top of the tube sheet. A person enters the plenum, which is on the clean side of the cartridges, and removes the cartridges up through the tube sheet; however, the venturis and compressed-air pipes must be removed first. Figure $D .2$ shows a variation on the walk-in plenum where the cartridges are located on both sides of a central aisle. The venturis and compressed-air lines are beneath the cartridges. Cleaning pulses are directed downward through the venturis to suck the particles from the cartridges and blow them down into a special hopper that prevents reentrainment. The rows of cartridges are also compartmentalized to prevent removed particles from migrating to neighboring cartridges during cleaning. 


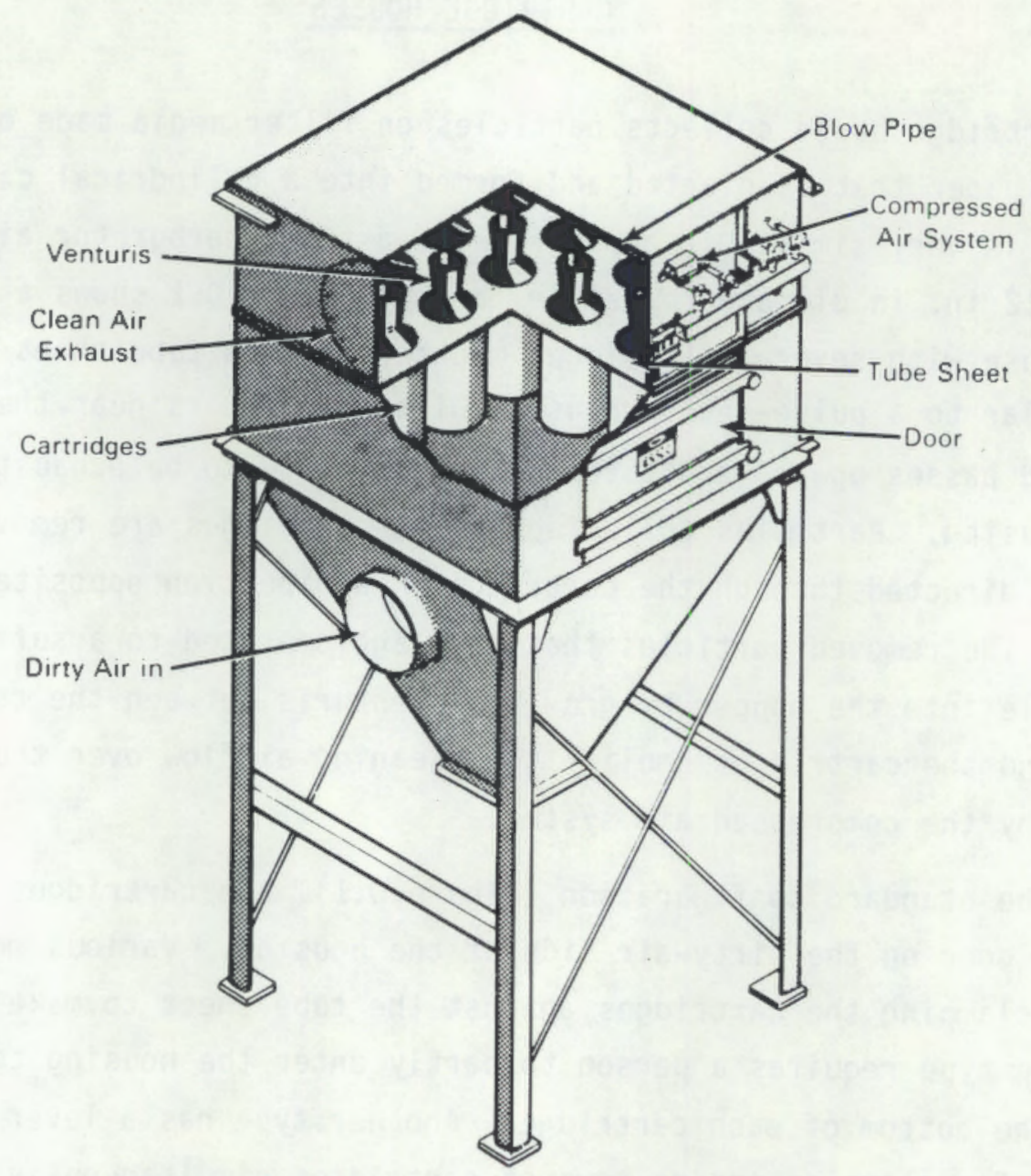

FIGURE 0.1. Typical Cartridge House

Figure $D .3$ shows another design where cartridges are mounted on a slight angle to the horizontal plane. The clean-air side, tube sheet, and pulse cleaning pipes are at the back of the cabinet. Pairs of cartridges are accessed through hatches on the front of the cabinet. This design has several more seals that must be checked for airtightness; however, with a modified hatch design, it lends itself to a type of bagout method for cartridge changes similar to that used in gloveboxes in the nuclear industry. The dirty airflow is from the top to the back of the cabinet, which would enhance the movement of particles to the hopper during pulse cleaning. The cartridges are also compartmentalized to reduce the tendency to blow particles to adjacent cartridges during cleaning. 


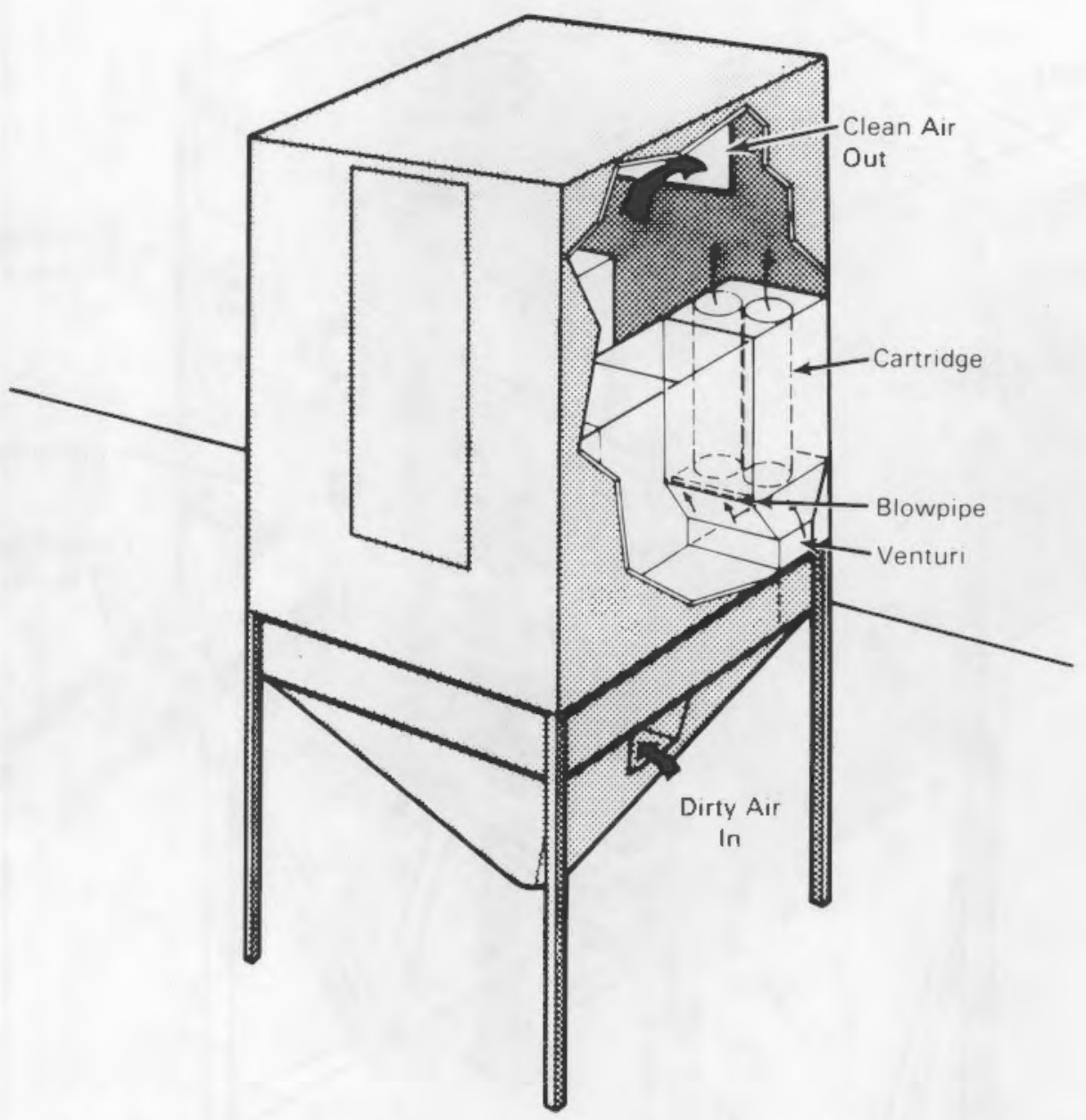

FIGURE 0.2. Walk-in Cartridge House

The cartridge houses are made of painted carbon steel. Most are a single housing except some that are available as multiple units in parallel or series.

\section{EFFICIENCY}

Two types of treated-cellulose paper cartridges are available. The standard media is available through all the vendors contacted. Efficiency data for these media were obtained from a vendor where measurements had been made using cascade impactors for a welding fume application. The particle size data were 


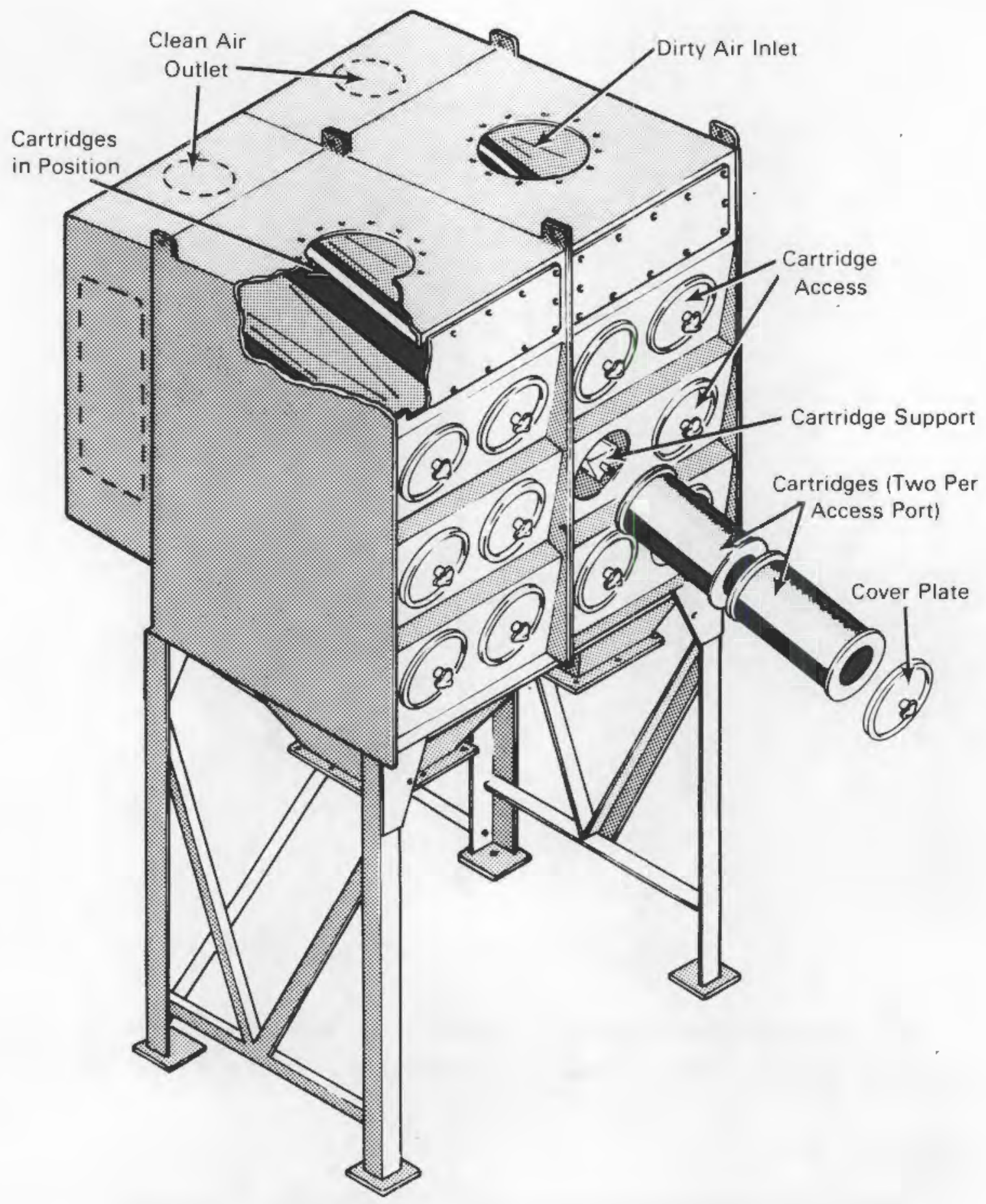

FIGURE D.3. Horizontal Mount Cartridge House 
in terms of aerodynamic particle size. A coated-cellulose cartridge media is also available. The fractional efficiency data for the coated media were obtained using an optical particle sizer and a calcium carbonate aerosol at a concentration of $2.3 \mathrm{~g} / \mathrm{m}^{3}$ upstream of the filter. Both sets of data were obtained during normal operation with regular cleaning cycles included; however, they are not as comparable as desired because of the different measurement methods used. The data, listed in Table 0.1 , show a greater efficiency for the coated than for the standard media. These data were used in the FILTER code to estimate usage of the downstream disposable filters. Cartridges with either type of media cost essentially the same.

\section{TABLE D.1. Filter Efficiency for Cartridges}

\begin{tabular}{cll}
$\begin{array}{c}\text { Particle } \\
\text { Diameter, } \mu m\end{array}$ & \multicolumn{1}{c}{$\begin{array}{l}\text { Standard } \\
\end{array}$} & \multicolumn{1}{c}{ Coated } \\
0.32 & $0.955^{\star}$ & $0.99955^{\star}$ \\
1.0 & 0.9971 & $0.999897^{\star}$ \\
3.2 & 0.99919 & 0.999977 \\
10.0 & 0.999795 & 0.999985 \\
32.0 & $0.999725^{\star}$ & $0.999946^{\star}$ \\
100.0 & $0.999833^{\star}$ & $0.9999725^{\star}$ \\
& $0.9999^{\star}$ & $0.99999^{\star}$
\end{tabular}

*Indicates value extrapolated beyond data.

\section{COST ESTIMATING}

Table 0.2 summarizes the descriptive information about the cartridge houses considered. Included are the maker, type of access for changing cartridges, number of cartridges, surface area of the filter media, wall thickness of the cabinet, compressed-air capacity required for cleaning mechanism, horsepower of the compressor, and the number of pulse valves that will require periodic maintenance.

Table 0.3 shows the estimated acquisition costs for the six cartridge houses. The initial cost of the cartridge house includes the first set of cartridge filters. The compressor estimate includes the air drier and heat tracing to prevent possible moisture freezing in the pulse valves in the winter. 
TABLE 0.2. Descriptive Summary of Cartridge Houses

\begin{tabular}{|c|c|c|c|c|c|c|c|}
\hline \multirow[b]{2}{*}{ Maker } & \multirow[b]{2}{*}{$\begin{array}{c}\text { Cartridge } \\
\text { Access }\end{array}$} & \multirow[b]{2}{*}{$\begin{array}{l}\text { Number of } \\
\text { Cartridges }\end{array}$} & \multirow[b]{2}{*}{$\begin{array}{l}\text { Cloth, } \\
\mathrm{ft}^{2}\end{array}$} & \multirow[b]{2}{*}{$\begin{array}{c}\text { Wall, } \\
\text { in. }\end{array}$} & \multicolumn{2}{|c|}{ Compresssor } & \multirow[b]{2}{*}{$\begin{array}{l}\text { No. } \\
\text { valves }\end{array}$} \\
\hline & & & & & $\begin{array}{l}\text { Air SCFM } \\
\text { at } 100 \mathrm{psi}\end{array}$ & $h_{p}$ & \\
\hline AA & $\mathrm{SH}^{(\mathrm{a})}$ & 46 & 9890 & 0.1046 & 12 & 5 & 23 \\
\hline DD & $T I(b)$ & 72 & 1548 & 0.12 & 24 & 7 & 12 \\
\hline $\mathrm{E}$ & SH & 56 & 12040 & 0.13 & 50 & 15 & 14 \\
\hline$B B$ & SH & 60 & 12900 & 0.1046 & 18 & 6 & 30 \\
\hline Z & SH & 72 & 154 & 0.13 & 32 & 7 & 12 \\
\hline $\mathrm{FF}$ & TI & 72 & 15480 & 0.1046 & 2 & 3 & 12 \\
\hline Avera & & 63 & 135 & 0.1 & 23 & 7 & 17 \\
\hline inimb & & 46 & 98 & 0.1 & 2 & 3 & 12 \\
\hline Maximum & & 72 & 15480 & 0.13 & 50 & 15 & 30 \\
\hline
\end{tabular}

(a) $\mathrm{SH}=$ cartridge access via hatch on side wall.

(b) $\mathrm{TI}=\mathrm{Ha} \mathrm{k}-$ in access above tube carbridge.

TABLE D.3. Cartridge House Acquisition Costs, Excluding Fan

\begin{tabular}{|c|c|c|c|c|}
\hline Maker & $\begin{array}{l}\text { Cartridge } \\
\text { House } \\
\text { w/bags, \$K }\end{array}$ & $\begin{array}{c}\text { Compressor, } \\
\text { SK }\end{array}$ & $\begin{array}{l}\text { Erection } \\
\text { Pad, Duct } \\
\text { etc., \$K }\end{array}$ & $\begin{array}{c}\text { Subtotal, } \\
\$ \mathrm{KK} \\
\end{array}$ \\
\hline $\begin{array}{l}\mathrm{AA} \\
\mathrm{DD} \\
\mathrm{E} \\
\mathrm{BB} \\
\mathrm{Z} \\
\mathrm{FF}\end{array}$ & $\begin{array}{l}23 \\
30 \\
29 \\
38 \\
42 \\
49\end{array}$ & $\begin{array}{r}5.6 \\
9.9 \\
14.8 \\
9.9 \\
9.9 \\
5.5\end{array}$ & $\begin{array}{l}61.3 \\
61.3 \\
61.3 \\
61.3 \\
61.3 \\
61.3\end{array}$ & $\begin{array}{r}89.9 \\
101.2 \\
105.4 \\
109.4 \\
112.7 \\
115.8\end{array}$ \\
\hline $\begin{array}{l}\text { Average } \\
\text { Minimum } \\
\text { Maximum }\end{array}$ & $\begin{array}{l}35.17 \\
23.00 \\
49.00\end{array}$ & $\begin{array}{r}9.27 \\
5.50 \\
14.80\end{array}$ & $\begin{array}{l}61.30 \\
61.30 \\
61.30\end{array}$ & $\begin{array}{r}105.73 \\
89.90 \\
115.80\end{array}$ \\
\hline
\end{tabular}

The erection cost assumes an installation outdoors with no building to cover the overall air cleaning system. Compressor and erection cost estimates are shown in Appendix K. Table D.4 lists the items included in the erection estimate. 
TABLE 0.4. Installation Costs of Cartridge House

\begin{tabular}{lr}
\multicolumn{1}{c}{ Item } & Cost, $\$$ \\
Pad $22 \times 30 \mathrm{ft}$ & 4700 \\
Compressor shelter & 2800 \\
Hopper shed & 5300 \\
Seven-gauge ducts & \\
$\quad$ and erection & 20900 \\
Electrical & 6400 \\
Freight & 1200 \\
Pressure test & 1900 \\
Drum scale & 8100 \\
Flow controls & 10000 \\
Total & 61300
\end{tabular}

Table 0.5 shows the estimated maintenance costs for a 20 -year life. The general method for these estimates was described in the main report (pages 1223). Additional assumptions beyond those stated in the main report were

- cartridges cost $\$ 65$ each

- cartridge compacts to $25 \%$ of original volume (1.92 $\left.\mathrm{ft}^{3}\right)$

- twelve cartridges can be compacted per man-hr

- cartridges have 2-year life, per manufacturers' data

- compressor operates $20 \%$ of the time

- cartridge changing requires 0.25 man-hr each.

In addition to the total estimated maintenance, Table 0.6 includes the cost of compressor operation.

Table 0.6 shows the estimates made by FILTER for the cost of operating the downstream disposable filters in various combinations for both types of media for 6000 test shots and $4900 \mathrm{~g}$ of challenge aerosol.

Fan requirements vary according to the combination of downstream banks of disposable filters. Table 0.7 lists the estimated static pressure requirenent, fan cost, and 20-year fan power cost for each combination of filter banks. The individual maximum pressure drops assumed were $1,4,4,4$, and 2.2 in. WG for the existing first prefilter, second prefilter and HEPA filter banks, cartridge house, and ductwork/shock attenuator system, respectively. 
TABLE 0.5. Twenty-Year Maintenance and Compressor Power Costs

\begin{tabular}{|c|c|c|c|c|c|c|c|c|c|c|c|c|}
\hline Maker & $\begin{array}{c}\text { Man-hr/ } \\
\text { Cartridge } \\
\text { Change }\end{array}$ & $\begin{array}{c}20-Y r \\
\text { Changenut } \\
\text { Labor, \$K }\end{array}$ & $\begin{array}{l}\text { Cartridge } \\
\text { 0isposal, } \\
\$ \mathrm{k} / 20 \mathrm{yr}\end{array}$ & $\begin{array}{l}\text { Dust } \\
\text { Disposal, } \\
\text { SK/6000 } \\
\text { Shots. }\end{array}$ & $\begin{array}{l}\text { Repair } \\
\text { Codes } \\
\text { CPAE B } \\
\end{array}$ & $\begin{array}{l}\text { Misc. } \\
\text { Repatis, } \\
\text { \$K }\end{array}$ & $\begin{array}{l}\text { Homsekeeping } \\
\text { and } \\
\text { Inspection. } \\
\text { day/yr }\end{array}$ & $\begin{array}{l}\text { Start-up } \\
\text { Shut down, } \\
\text { min/day }\end{array}$ & $\begin{array}{c}\text { Operation } \\
\text { Labor. } \\
\text { \$x. }\end{array}$ & $\begin{array}{c}\text { Cartridge } \\
\text { Replaceinent, } \\
\text { \$k/g Sets }\end{array}$ & $\begin{array}{c}\text { Subtotal } \\
\text { Cartridge } \\
\text { Maintenance. } \\
\text { SK }\end{array}$ & $\begin{array}{c}\text { Compressor } \\
\text { Power. } \\
\text { \$K }\end{array}$ \\
\hline $\begin{array}{l}A A \\
D D \\
E \\
B B \\
Z \\
F F\end{array}$ & $\begin{array}{l}12 \\
18 \\
14 \\
15 \\
18 \\
18\end{array}$ & $\begin{array}{l}3.57 \\
5.58 \\
4.34 \\
4.65 \\
5.58 \\
5.58\end{array}$ & $\begin{array}{r}6.71 \\
10.50 \\
8.17 \\
8.75 \\
10.50 \\
10.50\end{array}$ & $\begin{array}{l}24.08 \\
24.08 \\
24.08 \\
24.08 \\
24.08 \\
24.08\end{array}$ & $\begin{array}{llll}1 & 1 & 1 & 1 \\
1 & 1 & 1 & 1 \\
1 & 1 & 1 & 1 \\
1 & 1 & 1 & 1 \\
1 & 1 & 1 & 1 \\
1 & 1 & 1 & 1\end{array}$ & $\begin{array}{l}25.40 \\
21.62 \\
22.30 \\
27.81 \\
21.62 \\
21.62\end{array}$ & $\begin{array}{l}2 \\
2 \\
2 \\
2 \\
2 \\
2\end{array}$ & $\begin{array}{l}30 \\
30 \\
30 \\
30 \\
30 \\
30\end{array}$ & $\begin{array}{l}87.65 \\
87.65 \\
87.65 \\
87.65 \\
87.65 \\
87.65\end{array}$ & $\begin{array}{l}26.91 \\
42.12 \\
32.76 \\
35.10 \\
42.12 \\
42.12\end{array}$ & $\begin{array}{l}174 \\
192 \\
179 \\
188 \\
192 \\
192\end{array}$ & $\begin{array}{l}1.20 \\
1.68 \\
3.59 \\
1.44 \\
1.68 \\
0.72\end{array}$ \\
\hline $\begin{array}{l}\text { Average } \\
\text { Minimum } \\
\text { Maximum }\end{array}$ & $\begin{array}{l}16 \\
12 \\
18\end{array}$ & $\begin{array}{l}4.88 \\
3.57 \\
5.58\end{array}$ & $\begin{array}{r}9.19 \\
6.71 \\
10.50\end{array}$ & $\begin{array}{l}24.08 \\
24.08 \\
24.08\end{array}$ & & $\begin{array}{l}23.39 \\
21.62 \\
27.81\end{array}$ & $\begin{array}{l}2 \\
2 \\
2\end{array}$ & $\begin{array}{l}30 \\
30 \\
30\end{array}$ & $\begin{array}{l}87.65 \\
87.65 \\
87.65\end{array}$ & $\begin{array}{l}36.86 \\
26.91 \\
42.12\end{array}$ & $\begin{array}{l}186 \\
174 \\
19 ?\end{array}$ & $\begin{array}{l}1.72 \\
0.72 \\
3.59\end{array}$ \\
\hline
\end{tabular}

Repatr Code Key

C - annual compressar maintenance

P - semi-annual pulse valve rebullds

A - annual miscellaneous maintenance

E - one time replacement of cleaning cycle control
$B$ - one tinie bearing and other repair of blower

A - one tinie bearing and other repair of blower

A Linder the repair code column indicates that the repair is applicable to

in the cost estiunate. 
TABLE 0.6. Estimated Usage Costs of Disposable Filters

Downstream from Cartridge Houses

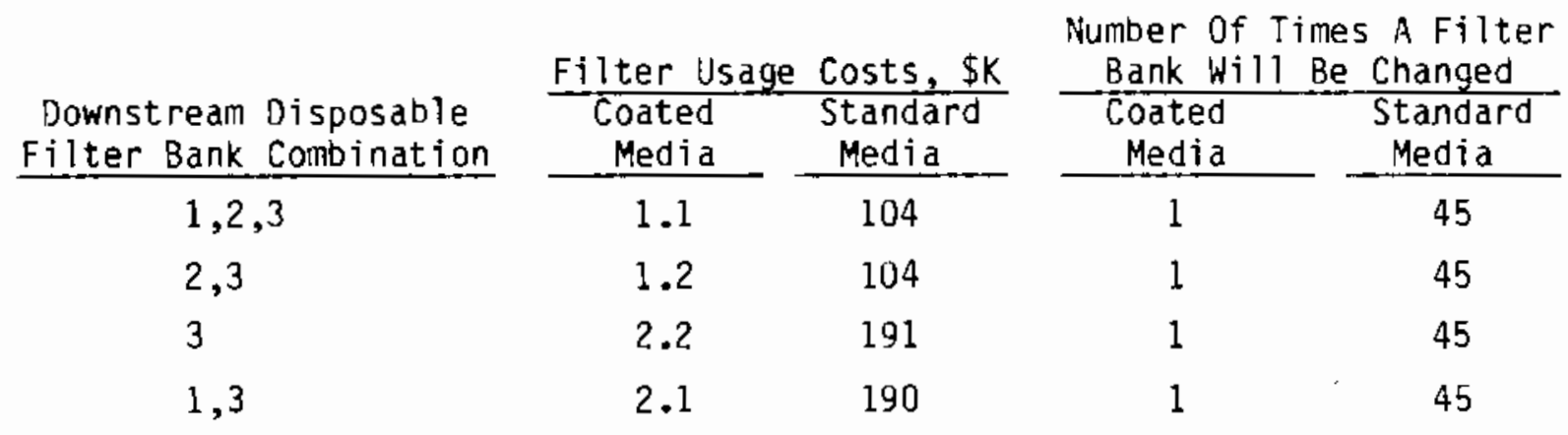

TABLE_.7. Fan Requirements for Cartridge Houses

\begin{tabular}{lllll} 
& \multicolumn{3}{c}{ Filter Bank Combination } \\
\cline { 2 - 3 } & $\frac{1,2,3}{3,3}$ & $\underline{2,3}$ & $\frac{1}{1.3}$ & $\frac{1,3}{11.2}$ \\
System Pressure Drop, in. WG & 15.2 & 14.2 & 10.2 & 11.2 \\
Fan Cost, \$K & 17 & 16 & 0 & 0 \\
Fan 20-yr Power Cost, \$K & 147 & 137 & 99 & 108
\end{tabular}

Table 0.8 sumarizes the 20 -year cost of acquiring and operating the six cartridge houses using standard cartridge media. Each entry in the maker versus bank combination matrix is the sum of acquisition, maintenance, disposable filter usage, and fan costs for the given configuration. Average, maxima, and minima for these total costs are also shown. The 20-year total power costs shown are the sum of the fan power cost and the average compressor power cost for all the units from Table D.5. The compressor power cost was only about $1 \%$ of the total power. The sum of the power cost and the equipment and maintenance average, maxima, and minima costs are also given in the table. Table D.9 shows the same data assuming coated media were used. 
TABLE D.8. Total Twenty-Year Cost of Cartridge Houses Using Standard Media

\begin{tabular}{|c|c|c|c|c|c|}
\hline \multirow[b]{2}{*}{ Maker } & \\
\hline & $1,2,3$ & 2,3 & 3 & 1,3 & Average \\
\hline $\mathrm{AA}$ & 385 & 384 & 455 & 454 & 420 \\
\hline $\mathrm{DD}$ & 414 & 413 & 484 & 483 & 448 \\
\hline $\mathrm{E}$ & 406 & 405 & 476 & 475 & 440 \\
\hline$B B$ & 418 & 417 & 488 & 487 & 453 \\
\hline 2 & 425 & 424 & 495 & 494 & 460 \\
\hline $\mathrm{FF}$ & 428 & 427 & 498 & 497 & 463 \\
\hline Average & 413 & 412 & 483 & 482 & 447 \\
\hline Minimum & 385 & 384 & 455 & 454 & 420 \\
\hline Maximum & 428 & 427 & 498 & 497 & 463 \\
\hline Power & 149 & 139 & 100 & 110 & 125 \\
\hline Power + Avg & 561 & 551 & 583 & 592 & 572 \\
\hline Power + Min & 534 & 523 & 556 & 564 & 544 \\
\hline Power + Max & 577 & 566 & 599 & 607 & 587 \\
\hline
\end{tabular}

TABLE D.9. Total Twenty-Year Cost of Cartridge Houses Using Coated Media

\begin{tabular}{|c|c|c|c|c|c|}
\hline & & Afte & ter & Comb & ion \\
\hline Maker & $1,2,3$ & 2,3 & 3 & 1,3 & Average \\
\hline AA & 282 & 281 & 266 & 266 & 274 \\
\hline DD & 311 & 310 & 295 & 295 & 303 \\
\hline $\mathrm{E}$ & 303 & 302 & 287 & 287 & 295 \\
\hline$B B$ & 316 & 315 & 300 & 300 & 307 \\
\hline$z$ & 322 & 321 & 306 & 306 & 314 \\
\hline FF & 325 & 325 & 310 & 309 & 317 \\
\hline Average & 310 & 309 & 294 & 294 & 302 \\
\hline Minimum & 282 & 281 & 266 & 266 & 274 \\
\hline Maximum & 325 & 325 & 310 & 309 & 317 \\
\hline Power & 149 & 139 & 100 & 110 & 125 \\
\hline Power + Avg & 459 & 448 & 394 & 404 & 426 \\
\hline Power + Min & 431 & 420 & 367 & 376 & 399 \\
\hline Power + Max & 474 & 464 & 410 & 419 & 442 \\
\hline
\end{tabular}


APPENDIX E

CYCLONES 
APPENDIX E

CYCLONES

\section{E.1 DESCRIPTION}

Cyclones separate particulates from the gas stream by transforming the flow stream into a confined vortex. Particles enter the cyclone following the gas streamlines. Flow through the cyclone vortex produces a tangential motion forcing the particles across the streamlines towards the collector wall. When the particles enter the boundary layer close to the cyclone wall they lose kinetic energy by viscous shear and mechanical friction. The two opposing forces involved are an outward centrifugal force, imparted by the rotation of the gas stream and an inward drag force which is a function of the particle density, diameter and shape. Any particle for which the centrifugal force is greater than the drag force will reach the wall and can be collected.

Cyclones are primarily used to collect large diameter, >10- $\mu$ m particles. To increase the collection efficiency for smaller particles, high-performance cyclones have been developed. High-performance cyclones have smaller inlet and outlet areas with smaller body diameter and longer overall length than conventional cyclones. The pressure drop across a high-performance cyclone is usually greater than $10 \mathrm{in}$. WG. Several small diameter cyclones operating in parallel also increase collection efficiency. As a last resort to increase efficiency, cyclones may be operated in series; however, the resulting pressure drop and energy requirements are extremely high. Figure E.1 shows a typical cyclone configuration.

Quotes and cyclone system configurations for the air cleaning system were obtained from three cyclone manufacturers. More than twenty cyclone manufacturers were initially contacted and invited to provide designs for the system. System designs for two collection efficiencies were requested: $90 \%$ and $60 \%$ to $70 \%$, for the aerosol size distribution with $30 \%$ of the particles $<1 \mu \mathrm{m}$ and $30 \%>7 \mu \mathrm{m}$ (Size Distribution No. 1, Tables 2 and 5 of the main text). None of the manufacturers would specify a systen for $90 \%$ collection 


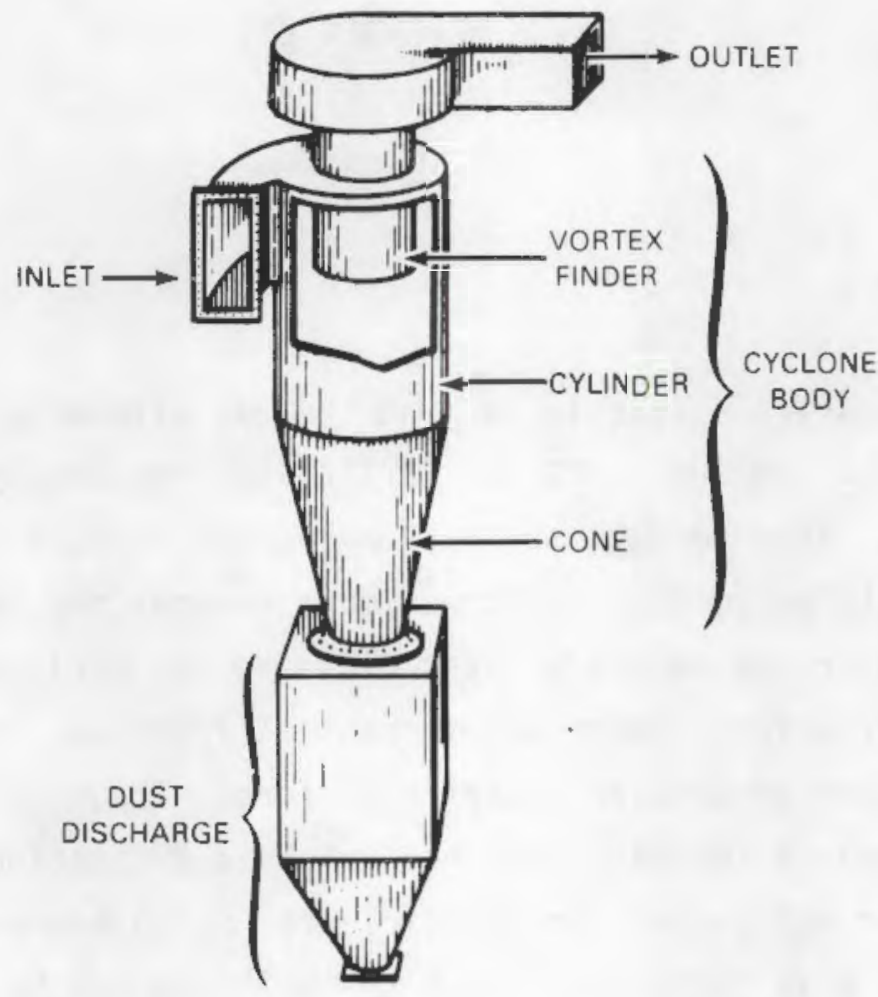

FIGURE E.1. Typical Cyclone Configuration (after Beachler and Jahnke 1981)

efficiency because $30 \%$ of the aerosol was $<1 \mu \mathrm{m}$ in diameter. Each of the vendors was able to specify a cyclone for $60 \%$ to $70 \%$ particulate collection (essentially all the particulate $\geq 1 \mu \mathrm{m}$ in dianeter). One proposed a single 123-in.-diameter high-performance cyclone. Another proposed four 35-in.-diameter cyclones in parallel, and a third proposed sixteen 27.5-in.-diameter cyclones in parallel. Table E.I shows the overall space requirements of the cyclone systems. Pressure drops for the cyclones, also listed in the table, are much higher than for most air filters discussed in this report, 11 to 16 in. WG.

The cyclone systems are constructed out of welded steel and require no maintenance over their 20-year projected life. The valve at the hopper outlet is the only moving part and requires periodic lubrication. For collection of an extremely abrasive particulate, wear plates can be installed at the cyclone inlet. The plates, which are replaced every 5 to 10 years as necessary, are not required for the aerosol in question. 
IABLE E.1. Cyclone System Specifications

\author{
Number of Cyclones \\ Body Diameter, in. \\ Inlet Height, in. \\ Inlet Width, in. \\ Outlet Length, in. \\ Outlet Diameter, in. \\ Cylinder Length, in. \\ Cone and Hopper Length, in. \\ Total Length, in. \\ Inlet Elevation, $\mathrm{ft}^{(\mathrm{b})}$ \\ Outlet Elevation, $\mathrm{ft}^{\text {(b) }}$ \\ Pad Size, $\mathrm{ft} \times \mathrm{ft}$ \\ Weight, ib \\ $\Delta P$, in. $W G$ \\ Construction
}

$\begin{array}{rrr}\text { Product } T & \text { Product } F & \text { Product } Q \\ 123 & 4 & 16 \\ 75 & 35 & 27.5 \\ 17 & -- & 11 \\ -- & 15(\text { a) } & 22.37 \\ 33.5 & -- & 16 \\ -- & 18 & 36 \\ 234 & -- & 56.5 \\ 293 & -- & 137 \\ 27.2 & 123 & 193.5 \\ 30.1 & 15 & 14.5 \\ 7 \times 7 & 10 \times 25 & 20 \times 30 \\ 10,400 & 5,000 & 10,000 \\ 16 & 12 & 10.7 \\ -- & 14-\text { gage } & \text { 10-gage hot } \\ & \text { mild steel } & \text { rolled steel }\end{array}$

(a) Diameter

(b) Assumes hopper out let $4 \mathrm{ft}$ above ground

The cyclone systems' costs are listed in Table F.?. The single cyclone costs half as much as the two multiclones. No installation costs were provided for Product $T$ or Product $F$. Very little site assembly is required for these systems. The units are placed on the pad and the connecting ductwork is attached. The Product $Q$ requires site assembly of four inlet and outlet manifolds, 16 product receivers, and 16 collection barrels. The installation cost provided for Product $Q$ was $\$ 165,000$. At startup, the pressure drops across each of the multiclones are balanced to ensure equal flow through each of the units. The flow balance should be checked biannually. 
TABLE E.2. Cyclone Costs

Cyclone System Cost

Installation and Site Assembly

Freight (a)

$$
\begin{array}{rrr}
\frac{\text { Product I }}{\$ 16,000} & \frac{\text { Product } F}{\$ 32,000} & \frac{\text { Product } Q}{\$ 37,366} \\
-- & -- & 155,000 \\
2,080 & 1,000 & 2,000
\end{array}
$$

(a) Estinated at $\$ 20 / 1001 \mathrm{~b}$.

\section{E.2 Collection Efficiency}

The vendors were asked to supply system collection efficiency as a function of particle size. Product $F$ and Product $T$ provided particle cut diameter $^{(\alpha)}$ and Product $Q$ provided a system total collection efficiency along with some fractional efficiencies as a function of stokes equivalent dianeter. The particle cut diameters were converted to collection efficiency as a function of particle size using Size Distribution 1 and the Lapple Method (Beachler and Jahnke 1981). The fractional efficiencies are listed in Table E.3.

The Lapple Method is one of the older methods of calculating cyclone fractional efficiency. The method was documented in 1951 before the development of high-performance cyclones. The method was applied to the Product $F$ and Product $T$ cyclones because the vendors did not provide any collection efficiency data as a function of particle size. Using the cut diameters of $3.0 \mu \mathrm{m}$ and $2.4 \mathrm{um}$ for Product $F$ and Product $T$, total collection efficiencies of $49.34 \%$ and $53.73 \%$ resulted, respectively. The vendors were asked to provide cyclones with collection efficiencies ranging from $60 \%$ to $70 \%$ assuming Size Distribution 1 (Table 5 from main text). However, because Size Distribution No. 3 (Table 5) was used, cyclones were assumed to have smaller cut diameters in order to achieve the required collection efficiencies. Therefore, 2.0-um and 1.5-um cut diameters were used for Product $F$ and Product $T$, respectively. These curves

(a) The particle cut diameter is that diameter for which the cyclone has $50 \%$ collection efficiency. 
TABLE E.3. Cyclone Fractional Collection Efficiencies

\begin{tabular}{|c|c|c|c|c|c|c|c|c|c|}
\hline Company & $\begin{array}{l}0.1 \\
\mu \mathrm{m}\end{array}$ & $\begin{array}{c}0.32 \\
\mu \mathrm{m} \\
\end{array}$ & $1.0 \mathrm{\mu m}$ & $\begin{array}{l}3.2 \\
\mu \mathrm{m}\end{array}$ & $\begin{array}{l}10 \\
\mu \mathrm{m} \\
\end{array}$ & $\begin{array}{l}32 \\
\mu \mathrm{m}\end{array}$ & $100 \mu \mathrm{m}$ & $\begin{array}{c}50 \% \text { Cut } \\
\text { Diameter, } \mu \mathrm{m}\end{array}$ & $\begin{array}{l}\text { Total Collection } \\
\text { Efficiency, } \%\end{array}$ \\
\hline Product $Q$ & 0 & 12 & 39.36 & 99 & 99.9 & 100 & $100^{(a)}$ & $\sim 1.1^{(b)}$ & $68.75(c)$ \\
\hline Product $F$ & 0 & 0.4 & 10.5 & 53 & 98 & 100 & $100^{(d)}$ & $3.0^{(c)}$ & $49.34^{(e)}$ \\
\hline Product T & 0 & 1.0 & 16 & 61 & 98 & 100 & $100^{(d)}$ & $2.4^{(c)}$ & $53.73^{(e)}$ \\
\hline
\end{tabular}

in $\quad$ Recommended for

Product $F$

$\begin{array}{lll}0 & 2 & 22\end{array}$

$71 \quad 99.5 \quad 100 \quad 100^{(d)}$

2.0

56.77

Recomnended for

Product $T$

$81 \quad 99.9 \quad 100 \quad 100^{(d)}$

1.5

61.62

(a) Calculated from the total efficiency and Stokes Equivalent Diameters and fractional efficiencies supplied by the vendor: $1.0 \mu \mathrm{m}(39.36 \%), 1.5 \mu \mathrm{m}(92.25 \%), 2.0 \mu \mathrm{m}(97.29 \%)$ and the Size Distribution No. 1 (Table 5).

(b) Determined from plot of fractional collection efficiency.

(c) Data supplied by vendor.

(d) Calculated from the $50 \%$ cut diameter using the Lapple Method.

(e) Calculated using the Lapple Method and Size Distribution No. 1 (Table 5). 
produce total collection efficiencies closer to those specified in the original requirement, $60 \%$ to $70 \%$. In addition they may account for cyclone design improvements made since 1951. A curve of experimental results and theoretical predictions in Beachler and Jahnke (1981) show that the Lapple theory is quite conservative for particles less than 2 um in diameter.

The Product $Q$ fractional efficiencies were determined from vendor data. The curve of collection efficiency as a function of particle size for the Product $Q$ data has a much steeper slope than the Lapple curve when plotted as a cumulative log normal distribution. A $50 \%$ cut diameter of 1.1 um for Product $Q$ was determined from the plot.

\section{E.3 COST ESTIMATING}

A descriptive summary of some of the important characteristics of the three cyclone systems is shown in Table E.4. Included in the table are the pressure drop across just the cyclone system, excluding filters and ducts; the cut diameter; the estimated overall cyclone efficiency for the challenge aerosol size distribution (Measurement 3 , see Table 5 in main text); the quantity of aerosol collected by the cyclone for the same size distribution as estimated by FILTER; the outlet elevation; and, the size of the required concrete pad. The same pad size for all cyclones was used because it is the size of a new pad needed to accomodate the existing filter house. Any excess space on the existing pad would be used to allow room for manipulating drums of collected particles.

Except for the cost associated with the disposable filters, the 20-year maintenance cost for the system is estimated in Table E.5. Cost estimates were made using the method outlined in the main report. The dust collected per shot from Table E.3 was the basis for estimating the dust disposal cost. Annual inspection, startup, and shutdown are the only other maintenance costs associated with cyclones.

Table E.6 shows the total first costs entailed in acquiring the cyclones. The vendor's cost estimate and the freight costs are taken from Table E.2. The erection cost for the Product Q cyclone was provided by the vendor. It is substantially higher than the others because of the amount of ductwork required 
TABLE E.4. Summary of Cyclone Characteristics

\begin{tabular}{|c|c|c|c|c|c|c|c|c|}
\hline Maker & Device & Type & $\begin{array}{c}\text { Unit } \\
\text { Pressure } \\
\text { Drop, in. WG }\end{array}$ & $\begin{array}{c}\text { Cut } \\
\text { ofameter, } \\
\text { um } \\
\end{array}$ & $\begin{array}{c}\text { Unit } \\
\text { Efficiency, } \\
q\end{array}$ & $\begin{array}{l}\text { Grams Dust } \\
\text { Collected } \\
\text { Per Shot } \\
\end{array}$ & $\begin{array}{c}\text { Outlet } \\
\text { Elevatton, } \\
\text { ft. } \\
\end{array}$ & $\begin{array}{l}\text { Pad } \\
\text { Requíred, } \\
\text { ft x ft }\end{array}$ \\
\hline $\begin{array}{l}Q \\
F \\
T\end{array}$ & $\begin{array}{l}16 \text { Parallel } \\
4 \text { Parallel } \\
\text { Single }\end{array}$ & $\begin{array}{l}\text { Cyclones } \\
\text { Cyclones } \\
\text { Cyclone }\end{array}$ & $\begin{array}{l}10.7 \\
12 \\
16\end{array}$ & $\begin{array}{l}3 \\
2.4\end{array}$ & $\begin{array}{l}40.6 \\
33.7 \\
36.7\end{array}$ & $\begin{array}{l}2325 \\
1948 \\
2098\end{array}$ & $\begin{array}{l}16 \\
18 \\
30\end{array}$ & $\begin{array}{l}20 \times 30 \\
20 \times 30 \\
20 \times 30\end{array}$ \\
\hline
\end{tabular}

TABLE E.5. Twenty-year System Maintenance

\begin{tabular}{|c|c|c|c|c|c|c|c|}
\hline Maker & $\begin{array}{c}\text { Dust } \\
\text { Disposal, } \\
\$ \mathrm{~K} / 6000 \\
\text { Shots } \\
\end{array}$ & $\begin{array}{l}\text { Repair } \\
\text { Codes } \\
\text { C PAEB }\end{array}$ & $\begin{array}{c}\text { Misc. } \\
\text { Repairs, } \\
\$ K \\
\end{array}$ & $\begin{array}{c}\text { Housekeeping } \\
\text { Inspection, } \\
\text { day/yr } \\
\end{array}$ & $\begin{array}{l}\text { Startup } \\
\text { Shutdown, } \\
\text { min/day }\end{array}$ & $\begin{array}{c}\text { Operation } \\
\text { Labor, } \\
\$ x\end{array}$ & $\begin{array}{c}\text { Subtotal } \\
\text { Maintenance, } \\
\$ K \\
\end{array}$ \\
\hline $\begin{array}{l}Q \\
\mathbf{F} \\
T\end{array}$ & $\begin{array}{r}11.43 \\
9.57 \\
10.31\end{array}$ & $\begin{array}{l}1 \\
1 \\
1\end{array}$ & $\begin{array}{l}9.92 \\
9.92 \\
9.92\end{array}$ & $\begin{array}{l}1.5 \\
1.5 \\
1.5\end{array}$ & $\begin{array}{l}20 \\
20 \\
20\end{array}$ & $\begin{array}{l}59.26 \\
59.26 \\
59.26\end{array}$ & $\begin{array}{l}80.61 \\
78.76 \\
79.49\end{array}$ \\
\hline
\end{tabular}

TABLE E.6. First Costs of Cyclones

\begin{tabular}{|c|c|c|c|c|}
\hline Maker & $\begin{array}{l}\text { Unit, } \\
\$ K\end{array}$ & $\begin{array}{l}\text { Erection } \\
\text { Pad, Duct, } \\
\text { etc., } \$ K\end{array}$ & $\begin{array}{c}\text { Freight, } \\
\$ K\end{array}$ & $\begin{array}{c}\text { Subtotal, } \\
\$ K\end{array}$ \\
\hline$Q$ & 37 & 165 & 2 & 204.00 \\
\hline $\mathrm{F}$ & 32 & 63.5 & 1 & 96.50 \\
\hline$T$ & 16 & 58.5 & 2.1 & 76.60 \\
\hline
\end{tabular}

to manifold together 16 cyclones. The erection costs for the other cyclones were estimated as detailed in Appendix $k$ and shown in Table E.7. An extra amount was added to the Product $F$ cycione to account for manifolding together four cyclones.

The costs associated with the disposable filters to be used downstream of the cyclones were estimated using FILTER and are listed in Table E.8 (third column) by combination of filter banks. Also shown are the number of times a filter bank replacement would occur during the 20-year lifetime, the overall 
TABLE E.7. Erection Cost Estimates for Cyclones

\begin{tabular}{|c|c|c|}
\hline Item & Product $F, \$$ & Product T, $\$$ \\
\hline Pad $22 \times 30 \mathrm{ft}$ & 4,700 & 4,700 \\
\hline Hopper Shed & 5,300 & 5,300 \\
\hline $\begin{array}{l}\text { 7-Gauge Ducts } \\
\text { and Erection }\end{array}$ & 20,900 & 20,900 \\
\hline Electrical & 6,400 & 6,400 \\
\hline Pressure Test & 1,900 & 1,900 \\
\hline Drum Scale & 8,100 & 8,100 \\
\hline Flow Controls & 10,000 & 10,000 \\
\hline Extra Manifolding & 5,000 & \\
\hline Total & $\$ 62,300$ & $\$ 57,300$ \\
\hline
\end{tabular}

system particle collection efficiency, and pressure drops. Note that the criterion efficiency established in Table 1 was not met by the calculated efficiencies. The fan costs were estimated from the pressure drop estimates and the cost estimates in Appendix $k$ and are added to the acquisition costs from Table E.6. Power costs were estimated using the method outlined in the main report. Filter usage, initial investment, and maintenance costs are totaled for each configuration in column 9 of Table E.8, and power costs are included in the last column. Excluding power, the 20-year cost ranges fron $\$ 3.9 M$ to $\$ 8.1 M$.

For comparing costs of the different types of equipment, the estinate for the Product $T$ cyclone with all three of the existing filter banks downstream was used. The cost estinated for the Product Q cyclone was sonewhat lower; however, the need for 16 hopper dumping locations was considered a significant disadvantage, so the single Product $T$ cyclone was selected instead. Except for the initial investment, the cyclones did not compare favorably with devices with greater efficiency for the challenge aerosol.

\section{REFERENCE}

Beachler, D. S., and J. A. Jahnke. 1981. APT I Course 413 Control of Particulate Emissions Student Manual. EPA 450/2-80-066, Northrop Services, Inc., Research Triangle Park, North Carolina. 
TABLE E.8. Twenty-year Total costs by Filter Combination

\begin{tabular}{|c|c|c|c|c|c|c|c|c|c|c|}
\hline Maker & $\begin{array}{c}\text { Bank } \\
\text { Combination }\end{array}$ & $\begin{array}{c}\text { Filter } \\
\text { Replacement, } \\
\$ K \\
\end{array}$ & $\begin{array}{l}\text { Number } \\
\text { Bank } \\
\text { Changes }\end{array}$ & $\begin{array}{c}\text { Systen } \\
\text { Efficiency, } \\
\%\end{array}$ & $\begin{array}{c}\text { System } \\
\Delta \mathrm{P}, \\
\text { in. W.G. }\end{array}$ & $\begin{array}{l}\text { Fan } \\
\text { Cost, } \\
\$ K \\
\end{array}$ & $\begin{array}{l}\text { Total } \\
\text { First } \\
\text { Cost, } \\
\$ K \\
\end{array}$ & $\begin{array}{l}\text { Equi pment } \\
\text { and Ma in- } \\
\text { tenance, } \$ K\end{array}$ & $\begin{array}{c}\text { Fan } \\
\text { Power, } \\
\$ K \\
\end{array}$ & $\begin{array}{l}\text { Total, } \\
\$ K\end{array}$ \\
\hline 0 & $\begin{array}{r}1,2,3 \\
2,3 \\
3 \\
1,3\end{array}$ & $\begin{array}{l}3566 \\
3575 \\
6898 \\
6876\end{array}$ & $\begin{array}{l}1612 \\
1609 \\
1608 \\
1610\end{array}$ & $\begin{array}{l}99.989 \\
99.989 \\
99.933 \\
99.933\end{array}$ & $\begin{array}{l}21.9 \\
20.9 \\
16.9 \\
17.9\end{array}$ & $\begin{array}{l}27 \\
27 \\
18 \\
18\end{array}$ & $\begin{array}{l}231 \\
231 \\
222 \\
222\end{array}$ & $\begin{array}{l}3878 \\
3887 \\
7200 \\
7178\end{array}$ & $\begin{array}{l}212 \\
202 \\
163 \\
173\end{array}$ & $\begin{array}{l}4089 \\
4089 \\
7364 \\
7351\end{array}$ \\
\hline $\mathrm{F}$ & $\begin{array}{r}1,2,3 \\
2,3 \\
3 \\
1,3\end{array}$ & $\begin{array}{l}3887 \\
4043 \\
7908 \\
7521\end{array}$ & $\begin{array}{l}1887 \\
1845 \\
1843 \\
1886\end{array}$ & $\begin{array}{l}99.989 \\
99.989 \\
99.932 \\
99.932\end{array}$ & $\begin{array}{l}23.2 \\
22.2 \\
18.2 \\
19.2\end{array}$ & $\begin{array}{l}27 \\
27 \\
27 \\
27\end{array}$ & $\begin{array}{l}124 \\
124 \\
124 \\
124\end{array}$ & $\begin{array}{l}4089 \\
4245 \\
8110 \\
7723\end{array}$ & $\begin{array}{l}224 \\
215 \\
176 \\
186\end{array}$ & $\begin{array}{l}4314 \\
4460 \\
8286 \\
7909\end{array}$ \\
\hline$T$ & $\begin{array}{r}1,2,3 \\
2,3 \\
3 \\
1,3\end{array}$ & $\begin{array}{l}3756 \\
3858 \\
7507 \\
7254\end{array}$ & $\begin{array}{l}1779 \\
1751 \\
1749 \\
1777\end{array}$ & $\begin{array}{l}99.989 \\
99.989 \\
99.93 \\
99.93\end{array}$ & $\begin{array}{l}27.2 \\
26.2 \\
22.2 \\
23.2\end{array}$ & $\begin{array}{l}35 \\
35 \\
27 \\
27\end{array}$ & $\begin{array}{l}112 \\
112 \\
104 \\
104\end{array}$ & $\begin{array}{l}3947 \\
4049 \\
7690 \\
7437\end{array}$ & $\begin{array}{l}263 \\
253 \\
215 \\
224\end{array}$ & $\begin{array}{l}4210 \\
4302 \\
7905 \\
7661\end{array}$ \\
\hline
\end{tabular}




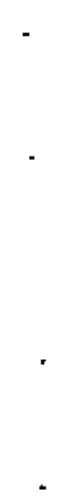


APPENDIX $F$

ELECTROSTATIC PRECIPITATORS 
APPENDIX F

\section{ELECTROSTATIC PRECIPITATORS}

Electrostatic precipitators collect particles that become electrically charged in an intense electric field. Particulate-laden gas flows through a chamber consisting of a series of discharge electrodes spaced equidistantly between grounded collection electrodes. The particles are charged and then inigrate to and are collected at the oppositely charged collection plates. The collected particles are removed from the plates by rapping. Particles fall by gravity into hoppers where they are stored before removal and final disposal.

Two types of precipitators exist: high-voltage single-stage and low-voltage two-stage. According to Beachler and Jahnke (1981), the two-stage, lowvoltage units have limited use for particle emission control because the collector becomes inefficient for dust loadings greater than $7.35 \times 10^{-4} \mathrm{~g} / \mathrm{m}^{3}$. The maximum dust load anticipated for this application is $3.4 \mathrm{~g} / \mathrm{m}^{3}$ with a $10-m i n$ average value of $0.5 \mathrm{~g} / \mathrm{m}^{3}$.

The two-stage electrostatic precipitator has separate particle charging and collection stages. In the single-stage unit the particles are charged and collected in the same stage.

Another major difference in the design of electrostatic precipitators is seen in the discharge electrode. Three major types of discharge electrode designs exist: the conventional weighted-wire electrode, the rigid frame electrode, and the needle plate electrode.

\section{PRECIPITATOR CONFIGURATIONS}

Quotes and electrostatic precipitator system configurations for the air cleaning system were obtained from five electrostatic precipitator manufacturers. More than 20 manufacturers were initially contacted and invited to provide designs for the system. Electrostatic precipitators are available for small $(6,000 \mathrm{acfm})$, medium $(24,000 \mathrm{acfm})$ and larye (coal-fired.power plants) scale applications. Companies that manufacture systems in all three categories responded to the inquiry. 
Vendor $K$, a manufacturer of small plant and process precipitators, recommended a configuration of 12 units operating in parallel. Vendor EE, a manufacturer of intermediate size precipitators, recommended a 24,000 acfin tubular poly-stage design. Vendor KK, Vendor $C C$, and Vendor $P$ all recommended modular versions of their large-scale units. Since the initial survey was conducted, Vendor $P$ has stopped marketing its precipitators in the United States.

System designs for two collection efficiencies were requested: $91 \%$ and $99 \%$ for the aerosol size distribution, $30 \%<1 \mu \mathrm{m}$ and $30 \%>7 \mu \mathrm{m}$. Each vendor provided a system designed to meet each collection efficiency. Because the precipitator designs vary, each design will be discussed separately. Table F.1 compares the precipitator specifications.

\section{TWO-STAGE PRECIPITATORS}

\section{Vendor $K$}

Vendor $K$ manufactures small two-stage electrostatic precipitators with separate ionization and collection stages. Several system configurations were recommended for the firing range application: drawer style, hopper style, and several self-contained units operated in parallel. Of the options presented, the hopper style system was best suited to handle the depleted uranium particulate. Figure F.1 presents Vendor K's sketch of the configuration. The design shows the units stacked three tiers high with a single hopper beneath each tier. The units are cleaned using rappers actuated by compressed air. No method was described to prevent dust reentrainment as it falls through the three tiers to the hoppers. The $\$ 24 K$ specified by Vendor $K$ for annual maintenance includes dust removal from the hoppers.

Vendor $k$ stated that the collection efficiency for the unit is essentially constant as a function of particle size. No evidence in the literature was found to support this statement, so the typical precipitator collection efficiency curve was used to describe the performance. 


\section{TABLE F.1. Comparison of the Electrostatic Precipitator Designs}

\begin{tabular}{|c|c|c|c|c|c|c|c|c|c|c|}
\hline & \multicolumn{2}{|c|}{ Vendor $k$} & \multicolumn{2}{|c|}{ Yendor EE } & \multicolumn{2}{|c|}{ Vendor $\mathrm{Kk}$} & \multicolumn{2}{|c|}{ Veasdor $\propto C$} & \multicolumn{2}{|c|}{ Vendor $P$} \\
\hline & 915 & -998 & 918 & 99 & 915 & 992 & $91 \overline{7}$ & 998 & 918 & $99 \%$ \\
\hline Number of units & 12 & 24 & 1 & 1 & 1 & 1 & 1 & 1 & 1 & 1 \\
\hline Number of Fields & 1 & 2 & $\mathbf{I}$ & 2 & 2 & 3 & 2 & 4 & 1 & 2 \\
\hline Number of Stages & 2 & 2 & 2 & 2 & $\mathbf{1}$ & 1 & 1 & $\mathbf{1}$ & 1 & 1 \\
\hline $\begin{array}{l}\text { Specific Collection Ared, } \\
\mathrm{ft}^{2} / 1000 \mathrm{acfm}\end{array}$ & -- & -- & 324 & 648 & 334 & 500 & 244 & 487 & 249 & 498 \\
\hline Plate Cleaning System & \multicolumn{2}{|c|}{$\begin{array}{l}\text { Compressed-air-actuated } \\
\text { rappers }\end{array}$} & \multicolumn{2}{|c|}{$\begin{array}{l}\text { Compressed-air-actuated } \\
\text { sonic horn }\end{array}$} & \multicolumn{2}{|c|}{$\begin{array}{l}\text { Compressed-air-actuated } \\
\text { rappers }\end{array}$} & \multicolumn{2}{|c|}{ Tumbling hamners } & \multicolumn{2}{|c|}{ Tumbling hamners } \\
\hline nust Collection System & \multicolumn{2}{|c|}{ Hoppers } & Hoppers and & crew conveyor & \multicolumn{2}{|c|}{ Hoppers } & \multicolumn{2}{|c|}{ Hoppers } & \multicolumn{2}{|c|}{ Hoppers } \\
\hline Nunber of Hoppers & 4 & B & 1 & 2 & 2 & 3 & 2 & 4 & 2 & 4 \\
\hline Pad Size, ft $\times f t$ & $5 \times 15$ & $10 \times 15$ & $8 \times 8$ & $8 \times 16$ & $16.3 \times 13.4$ & $21.9 \times 13.4$ & $38 \times 25$ & $62 \times 25$ & $17 \times 13$ & $34 \times 13$ \\
\hline Weight, ib & 6,000 & 12,000 & 16,000 & 32,000 & 49,000 & 73,000 & 70,000 & 140,000 & 43,400 & 80,000 \\
\hline Inlet Elevation, ft & \multicolumn{2}{|c|}{$12.5^{(a)}$} & 2.5 & 2.5 & \multicolumn{2}{|c|}{$22.5^{(0)}$} & \multicolumn{2}{|c|}{$20^{(a)}$} & \multicolumn{2}{|c|}{$22.5^{(a)}$} \\
\hline Out let Elevation, ft & \multicolumn{2}{|c|}{$12.5^{(d)}$} & 17.5 & .17 .5 & \multicolumn{2}{|c|}{$22.5(a)$} & \multicolumn{2}{|c|}{$20^{(a)}$} & \multicolumn{2}{|c|}{$22.5^{(a)}$} \\
\hline$\Delta P$, in $W G$ & 1.0 & 1.0 & 1.5 & 1.5 & 0.5 & 0.5 & 1.0 & 1.0 & 0.5 & 0.5 \\
\hline \multicolumn{11}{|l|}{ Power Requírements, $\mathrm{kW}$} \\
\hline $\begin{array}{l}\text { Particle Charging } \\
\text { Purge air heaters for insu- } \\
\text { lator canpartinent } \\
\text { Auxill ary }\end{array}$ & $1 . ?$ & 2.4 & $\begin{array}{l}10 \\
8.8\end{array}$ & $\begin{array}{l}20 \\
17.6\end{array}$ & $\begin{array}{l}5.2 \\
3.0^{(b)}\end{array}$ & $\begin{array}{l}7.8 \\
3.0^{(b)}\end{array}$ & $\begin{array}{l}22 \\
2.0 \\
(c)\end{array}$ & $\begin{array}{c}44 \\
2.0(c)\end{array}$ & $\begin{array}{l}3.6 \\
8.0\end{array}$ & $\begin{array}{r}7.2 \\
16.0\end{array}$ \\
\hline Annual Maintenance, s & $24,000^{(d)}$ & $24,000^{(d)}$ & $5,000^{(e)}$ & $5,000(e)$ & $1750^{(f)}$ & $2100(f)$ & $1 \mathrm{~d} / \mathrm{yr}$ & $1 \mathrm{~d} / \mathrm{yr}$ & 3,500 & 3,500 \\
\hline Required Accessories & \multicolumn{2}{|c|}{$\begin{array}{l}\text { Air compressor } \\
\text { size not specified }\end{array}$} & \multicolumn{2}{|c|}{$\begin{array}{l}\text { Air compressor } \\
20 \mathrm{cfm} \text { at } 80 \mathrm{psi}\end{array}$} & \multicolumn{2}{|c|}{$\begin{array}{l}\text { Air compressor } \\
20 \mathrm{cfm} \text { at } 50 \mathrm{psi}\end{array}$} & \multicolumn{2}{|c|}{ none } & \multicolumn{2}{|c|}{ none } \\
\hline Startup Time, min & \multicolumn{2}{|c|}{10} & 10 & 30 & \multicolumn{2}{|c|}{ none } & \multicolumn{2}{|c|}{ none } & \multicolumn{2}{|c|}{$\begin{array}{l}2 \mathrm{hr} \text { for insulator } \\
\text { heaters to warn up }\end{array}$} \\
\hline
\end{tabular}

\footnotetext{
(a) Assumes 4-ft clearance from ground to hopper bottom.

b) Insulator heaters $0.1 \mathrm{kH}$, vibrators $0.1 \mathrm{kH}$, rapping $0.6 \mathrm{~kW}$, contral system $0.8 \mathrm{~kW}$, lights for safety $1.4 \mathrm{~kW}$.

c) Hopper heaters at 90 to $100^{\circ} \mathrm{F}$ for $1 / 3$ of year and plate rapplog.

(d) Includes dust removal.

e) Includes man-hr and replacement parts.

(f) $0.5 \%$ of total cost.
} 


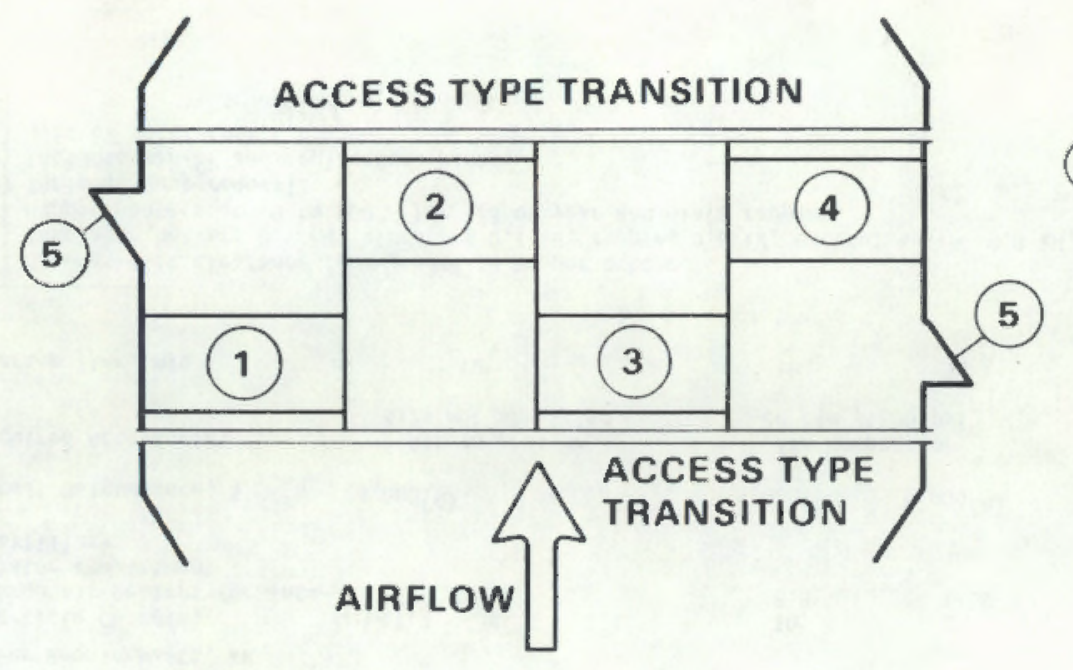

(1) (2) (3) (4) PRECIPITATOR MODULES
(EACH 3 TIERS HIGH)

(A) (B) (C) Individual tieRs OF COLlectors IN EACH PRECIP. MODULE

(5) ACCESS HATCHES

(6) DUST HOPPERS

(7) LEg STRUCTURE

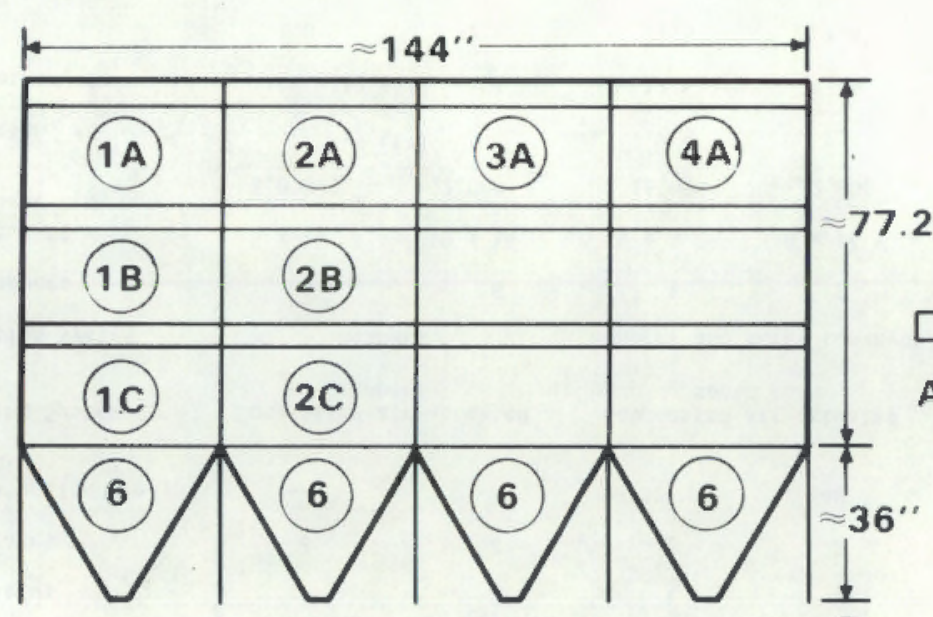

(7)

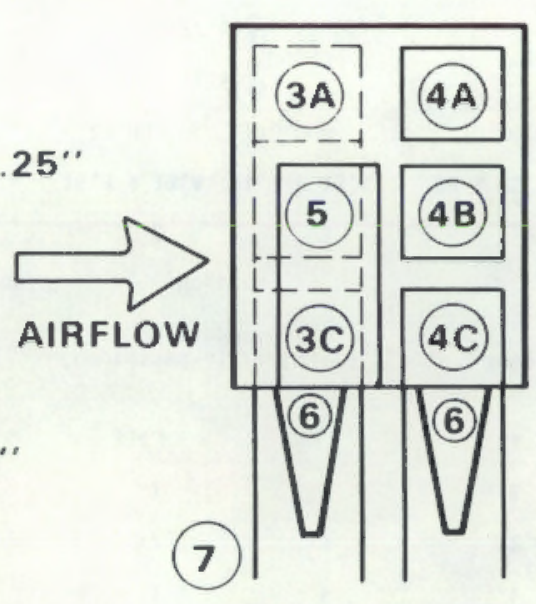

SIDE ELEVATION

INLET \& OUTLET FACE ELEVATION

FIGURE F.1. Vendor $\mathrm{K}$ Systen Configuration 


\section{Vendor EE}

Vendor EE manufactures a tubular electrostatic precipitator. This is also a two-stage electrostatic precipitator, but the design departs from the conventional two-stage design. Figure F.2 shows a cross section of the unit. The ionizing electrode is shaped like a rod with a sharp needle at the end. The corona is generated on the needle and the remainder of the electrode acts as a nondischarging electrode, which still provides an electric field. This design provides a nonuniform electric field in the ionizing section and a uniform electric field in the collecting section.

Vendor EE recommended a one-pass unit to achieve $91 \%$ collection efficiency and a two-pass unit to achieve $99 \%$ collection efficiency. In addition, they recommend that a pilot test be run to allow the design to be further refined because a very conservative specific collection area (324 $\mathrm{ft}^{2} / 1000$ acfm per pass) was used for the design.

Most Vendor EE systems operate wet using a continuous water mist to clean the collection surfaces. When water use is not feasible, sonic horns are used to dislodge the particulate. Compressed air requirements are $20 \mathrm{acfm}$ and 80 psia to actuate the sonic horn. No users of the sonic cleaning method could be found to verify its performance.

Power requirements for the $99 \%$ collection efficiency unit are $20 \mathrm{~kW}$ for particle charging and $17.6 \mathrm{~kW}$ for pulse air heaters. Hot, dry air (150 to $180^{\circ} \mathrm{F}$ ) is blown through the insulator compartment (200 acfm for 16 insulators) to keep the insulators dust and moisture free.

Vendor EE estimates annual maintenance costs to be $\$ 5 K$. This figure includes labor and replacement parts.

\section{SINGLE-STAGE PRECIPITATORS}

Vendor KK

Vendor KK manufactures an electrostatic precipitator for industrial applications for small volume flow $(3,000$ to $25,000 \mathrm{acfm})$. The precipitator uses a needle/plate electrode system instead of weighted corona wires. 


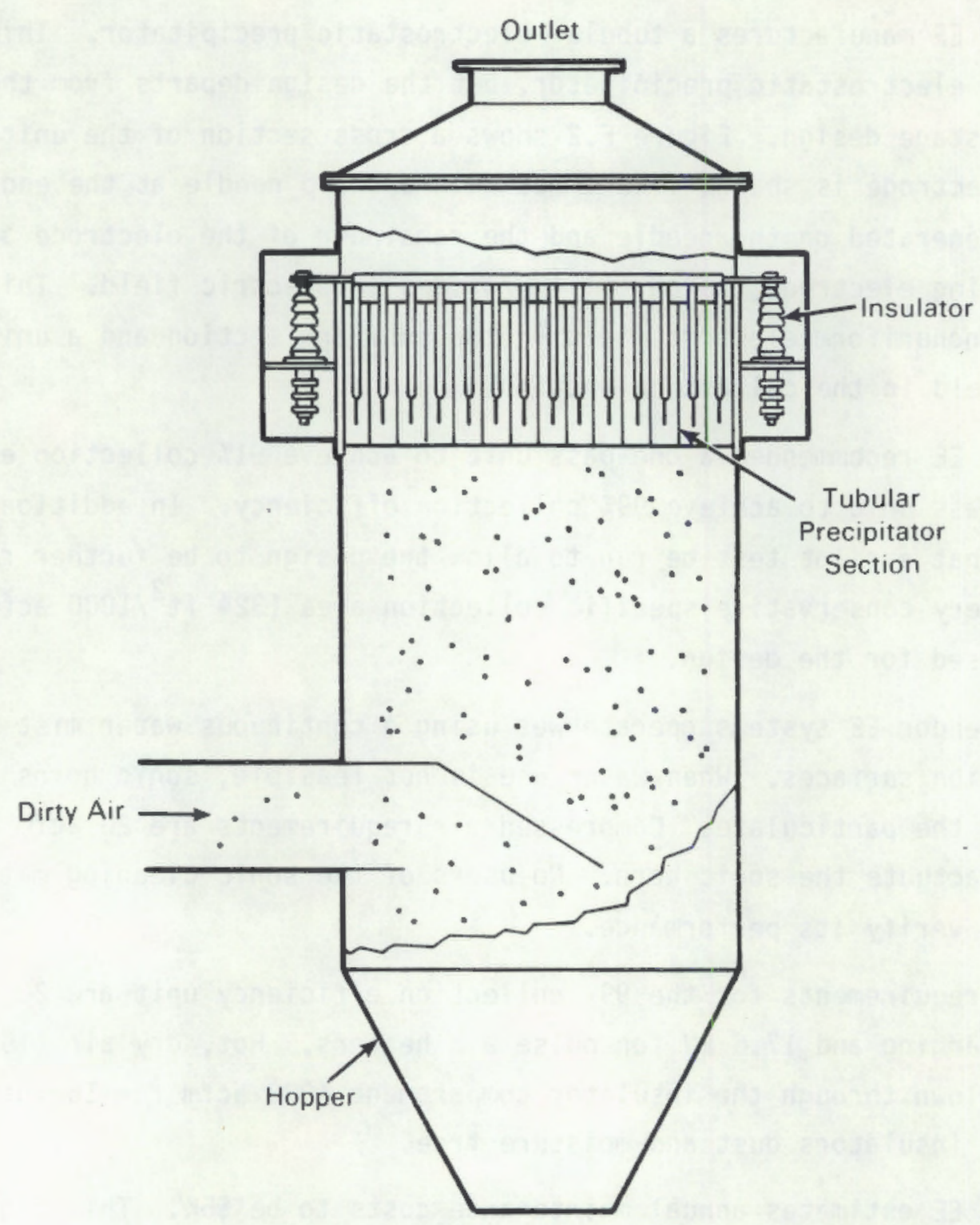

FIGURE F.2. Vendor EE Tubular Electrostatic Precipitator

Figure F.3 shows the design of the discharge electrodes and collection plates. Vendor KK recommended a two-field unit to achieve $91 \%$ collection efficiency and a three-field unit to achieve $99 \%$ collection efficiency. Collected dust is removed by a compressed-air-actuated plate rapping system. Compressed-air 
requirements are $20 \mathrm{cfm}$ at $50 \mathrm{psig.} \mathrm{The} \mathrm{precipitators} \mathrm{are} \mathrm{factory} \mathrm{assembled}$ and shipped to the site fully wired, piped, and insulated on two flatbed trucks or one rail car. The collection hoppers and attached structural leg unit are bolted to the concrete or steel foundation supplied by the owner. Then the precipitator is set on top and bolted to the hopper flange. Maintenance requirements are minimal and are estimated to be $0.5 \%$ of the total cost.

Power requirements for particle charging for the $91 \%$ and $99 \%$ collection efficiency designs range from 5.2 to $7.8 \mathrm{~kW}$, with an additional $2.8 \mathrm{~kW}$ required to power the precipitator auxilliary systems.

\section{Vendor CC}

Vendor CC manufactures an electrostatic precipitator using a rigid frame discharge electrode with a 3/16-in.-square corona wire. Vendor CC specified a two-field precipitator to achieve $91 \%$ collection efficiency and a four-field

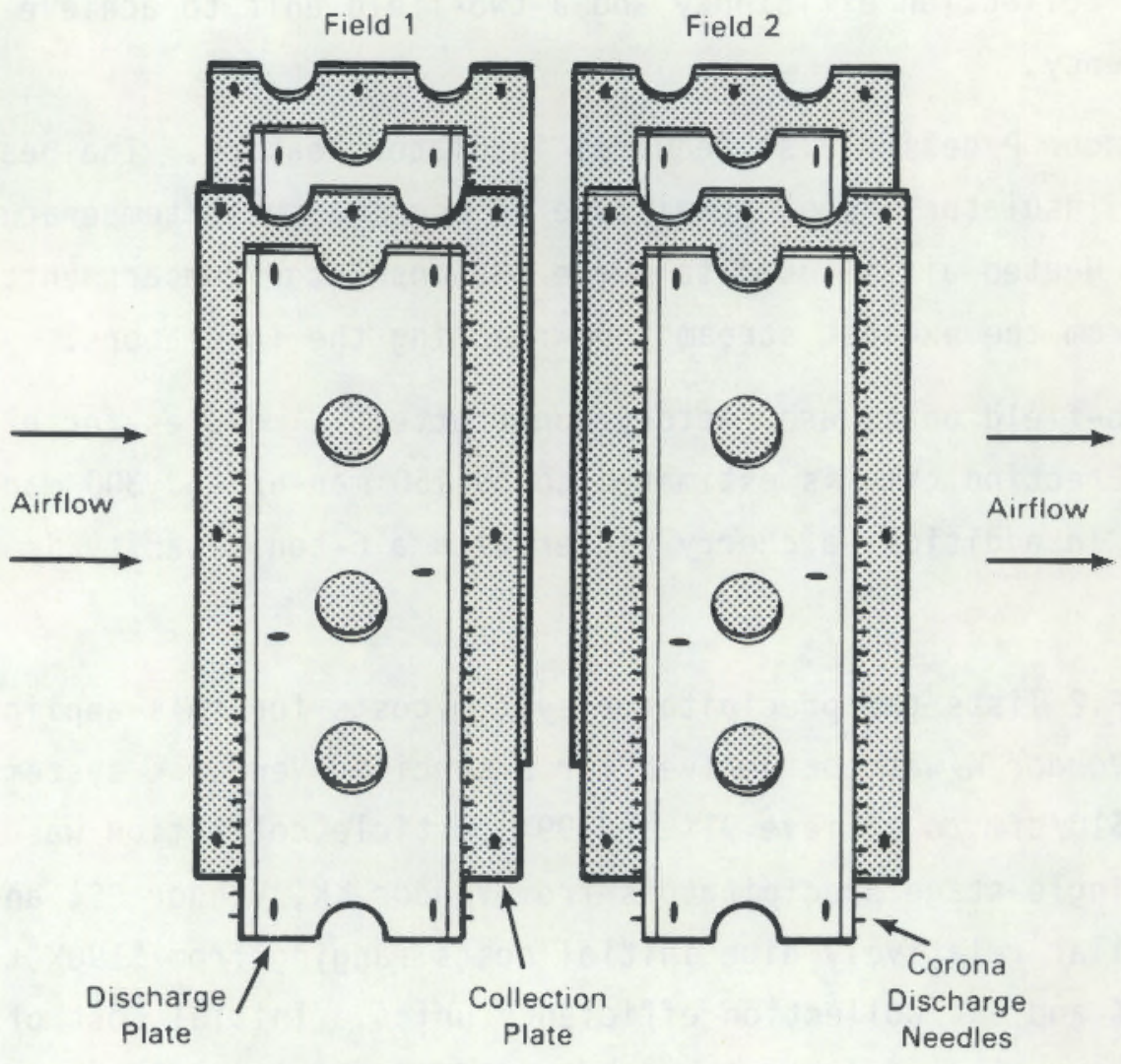

FIGURE F.3. Discharge Electrode Plates with Needles 
precipitator to achieve $99 \%$ collection efficiency. The precipitator assembly is built as a set of modular components to allow quick field installation. One precipitator module, which includes the collecting and emitting electrodes, rapping system, high-voltage insulators, and insulator heaters, is required for each electrical field. One hopper is required under each precipitator module.

Precipitator power requirements for particle charging are $22 \mathrm{~kW}$ for the two-field unit and $44 \mathrm{~kW}$ for the four-field unit. Because these power requirements are from two to ten times larger than those of the other precipitator designs, Vendor CC was asked to recheck the requirements. No change in value or explanation for the large usage resulted. Additional power requirements for hopper heaters and rapping are $2 \mathrm{~kW}$.

\section{Vendor $\mathrm{P}$}

Vendor $P$ markets a single-stage precipitator using the classic wire-weight design for the discharge electrode. Vendor $P$ recommends a single-field unit to achieve $91 \%$ collection efficiency and a two-field unit to achieve $99 \%$ collection efficiency.

The Vendor $P$ design also requires insulator heaters. The heaters are used to keep the insulators free of moisture by keeping their temperature above the dew point. Heated air is used to purge the insulator compartment. This prevents air from the exhaust stream from reaching the insulators.

The two-field units are factory constructed in modules for efficient site assembly. Erection time is estimated to be 150 man-hr and 300 man-hr for the two units. In addition, a cherry picker with a 6-ton capacity is required. $\underline{\text { Cost }}$

Table F.2 lists the precipitator system costs for this application. 'The value from vendor $K$ was not derived for a specific Vendor $K$ system. A cost of $\$ 5 / \mathrm{cfm}$ and $\$ 10 / \mathrm{cfm}$ to achieve $91 \%$ and $99 \%$ particle collection was furnished. The three single-stage precipitators from Vendor KK, Vendor CC, and Vendor $P$ all had similar relatively high initial costs ranging from $\$ 190 \mathrm{~K}$ to $\$ 418 \mathrm{~K}$ for both the $91 \%$ and $99 \%$ collection efficiency units. Initial cost of the Vendor EE two-stage precipitator was less than half of the initial costs of the single-stage units. 
TABLE F.2. Electrostatic Precipitator Costs

\begin{tabular}{|c|c|c|c|c|c|c|c|c|c|c|}
\hline & \multirow{2}{*}{\multicolumn{2}{|c|}{$91 \%$ Vendor $K$}} & \multicolumn{2}{|c|}{ Vendor EE } & \multicolumn{2}{|c|}{ Vendor KK } & \multicolumn{2}{|c|}{ Vendor CC } & \multicolumn{2}{|c|}{ Vendor $P$} \\
\hline & & & $91 \%$ & $99 \%$ & & $99 \%$ & $91 \%$ & 90 & $91 \%$ & 99\% \\
\hline $\begin{array}{l}\text { Precipitator System } \\
\text { Cost, \$ }\end{array}$ & 120,000 & 240,000 & 84,068 & 168,136 & 314,800 & 384,800 & 209,400 & 418,800 & 190,000 & 350,000 \\
\hline $\begin{array}{l}\text { Installation and site } \\
\text { Assembly, s }\end{array}$ & -- & -- & - & -- & 20,000 & 20,000 & 80,000 & 157,000 & $150 \mathrm{hr}$ & $300 \mathrm{hr}$ \\
\hline Freight, $\$$ & -- & $\cdots$ & 3,200 & 6,400 & 9,200 & 9,200 & 4,000 & 8,000 & -- & - \\
\hline
\end{tabular}


Cost of operating the precipitators is a function of electrical consumption and pressure drop. All the units have extremely low pressure drops ranging from 0.5 to $1.5 \mathrm{in}$. WG. The electrical requirements for the five systems range from 2.4 to $44 \mathrm{~kW}$ for particle charging for $99 \%$ collection efficiency. In addition, Vendor EE and Vendor $P$ designs also require substantial power for insulator compartment heaters (see Table F.1).

\section{COLLECTION EFFICIENCY}

No collection efficiency data as a function of particle size were furnished by any of the precipitator manufacturers. All of the vendors replied that their units would collect $91 \%$ or $99 \%$ of the aerosol size distribution provided in the design specifications. All of the units appear to have been designed rather conservatively as shown by the large specific collection areas (SCA), which range from 244 to $344 \mathrm{ft}^{2}$ of collection electrode/1000 acfm for the $91 \%$ design to 487 to $648 \mathrm{ft}^{2} / 1000$ acfm for the $99 \%$ design. According to Beachler and Jahnke (1981), to achieve $99.5 \%$ collection efficiency the SCA should range from 350 to $400 \mathrm{ft}^{2} / 1000 \mathrm{acfm}$.

The fractional efficiency for each precipitator size range was determined from a curve of theoretical collection efficiency as a function of particle size (Bethea 1978). Using the theoretical curve and the particle size distribution specified in the initial design, a collection efficiency of $99.1 \%$ was obtained. To determine the fractional efficiency for $91 \%$ total collection efficiency, a family of similar curves was drawn beneath the theoretical collection efficiency curve. The curve chosen produced a total collection efficiency of $91.7 \%$ for the specified size distribution.

Three particle size distributions of the firing range aerosol have been measured as shown in Tables 2 and 5 in the main text. The more conservative size distribution No. 3 data were finally used to evaluate the precipitators. Table F.3 presents the collection efficiencies for $91 \%$ and $99 \%$ total collection efficiency derived using both Size Distributions No. 1 and 3 . 
TABLE F.3. Electrostatic Precipitator Collection Efficiency as a Function of Particle Size

\begin{tabular}{|c|c|c|c|c|c|c|c|c|}
\hline Part & Total Collection & & $x-11$ ac & ional $c$ & lection & Efficier & & \\
\hline put 101 & Efficiency, $\%$ & $0.1 \mu m$ & $0.32 \mathrm{~mm}$ & $1.0 \mu \mathrm{m}$ & $3.2 \mu \mathrm{m}$ & $10.0 \mu \mathrm{m}$ & $32.0 \mu m$ & $100 \quad \mu m$ \\
\hline $\begin{array}{l}\text { No. } 3 \\
\text { No. } 3 \\
\text { No. } 1 \\
\text { No. } 1\end{array}$ & $\begin{array}{l}99 \\
91 \\
99 \\
91\end{array}$ & $\begin{array}{c}98.5 \\
86 \\
98 \\
78\end{array}$ & $\begin{array}{c}97.5 \\
81 \\
96.5 \\
73\end{array}$ & $\begin{array}{c}99.2 \\
90 \\
98.8 \\
86 .\end{array}$ & $\begin{array}{l}99.98 \\
99.4 \\
99.98 \\
98.8\end{array}$ & $\begin{array}{l}100 \\
100 \\
100 \\
99.99\end{array}$ & $\begin{array}{l}100 \\
100 \\
100 \\
100\end{array}$ & $\begin{array}{l}100 \\
100 \\
100 \\
100\end{array}$ \\
\hline
\end{tabular}

\section{COST ESTIMATING}

Several of the important characteristics of the precipitators are summarized in Table F.4. The efficiency values listed are those calculated by FILTER for each precipitator and the finest challenge aerosol size distribution using the data of Table F.3. The specific collection area is the area of collection plates per 1000 acfm of airflow. The first column of power data is that electricity needed to operate the collection electrodes, purge air, and hopper heaters. The auxiliary equipment power is that needed for the air compressors or tumbling rappers that are used intermittently as estimated in the "Run Fraction" column.

Table F.5 shows a summary of the acquisition costs of the precipitator systems. The auxiliary equipment cost is for the required air compressor for the rapping systems. The installation cost is for installation of the precipitators beyond what is already accounted for under erection and ductwork. The cost used in most cases was that provided by Vendor KK. Vendor CC supplied their own erection cost, which accounts for a large amount of onsite fabrication. The erection cost was estimated as shown in Table F.6.

Estimates for precipitator maintenance are shown in Table F.7. The cost estimating methods are outlined in the main report ( $p p .12-23$ ). Equipment maintenance includes 16 man-hr/yr for miscellaneous maintenance; a one time insulator replacement of $\$ 500$, including labor; and a control board replacement ( $\$ 500$ for parts, 4 man-hr labor). Where compressors are used, 16 man-hr/yr was included as a maintenance estimate.

Table F.8 shows various performance data and total costs for each combination of precipitator and disposable filter bank combination. The existing 
TABLE F.4. Summary of Electrostatic Precipitator Characteristics

\begin{tabular}{|c|c|c|c|c|c|c|c|c|}
\hline Maker & $\begin{array}{c}\text { Device } \\
\text { Type }\end{array}$ & $\begin{array}{c}\text { Efficiency, } \\
\qquad\end{array}$ & $\begin{array}{c}\text { Speciffc } \\
\text { Collection } \\
\text { Area, } \\
\mathrm{ft}^{2} / 1000, \text { acfm }\end{array}$ & $\begin{array}{c}\text { Power, } \\
\text { kw }\end{array}$ & $\begin{array}{c}\text { Pad Size, } \\
\mathrm{ft}\end{array}$ & $\begin{array}{c}\text { Dust } \\
\text { Collected } \\
\text { Per Shot, g }\end{array}$ & $\begin{array}{l}\text { Number of } \\
\text { Insulators }\end{array}$ & $\begin{array}{c}\text { Auxiliary } \\
\text { Run Fraction, } \\
\text { hr/hr }\end{array}$ \\
\hline $\begin{array}{l}\mathrm{EE} \\
\mathrm{K} \\
\mathrm{KK} \\
\mathrm{CC} \\
\mathrm{EE} \\
\mathrm{K} \\
\mathrm{KK} \\
\mathrm{CC}\end{array}$ & $\begin{array}{l}\text { 1-field, 2-stage, tubular } \\
\text { 1-field, } 2 \text { stage } \\
\text { 2-field, 1-stage } \\
\text { 2-field, 1-stage } \\
\text { 2-field, 2-stage, tubular } \\
\text { 2-field, 2-stage } \\
\text { 3-field, 1-stage } \\
\text { 4-field, 1 stage }\end{array}$ & $\begin{array}{l}91.4 \\
91.4 \\
91.4 \\
91.4 \\
99.1 \\
99.1 \\
99.1 \\
99.1\end{array}$ & $\begin{array}{l}324 \\
334 \\
244 \\
648 \\
\\
500 \\
487\end{array}$ & $\begin{array}{r}18.8 \\
1.2 \\
6.2 \\
22.5 \\
37.6 \\
1.2 \\
8.8 \\
44.5\end{array}$ & $\begin{array}{l}22 \times 30 \\
22 \times 30 \\
22 \times 30 \\
1600 \mathrm{sq} \\
22 \times 30 \\
22 \times 30 \\
22 \times 30 \\
1600 \mathrm{sq} \\
\mathrm{ft}\end{array}$ & $\begin{array}{l}4480 \\
4480 \\
4480 \\
4480 \\
4854 \\
4854 \\
4854 \\
4854\end{array}$ & $\begin{array}{l}4 \\
6 \\
4 \\
8 \\
9 \\
9 \\
8\end{array}$ & $\begin{array}{l}0.2 \\
0.2 \\
0.2 \\
0.3 \\
0.2 \\
0.2 \\
0.2 \\
0.33\end{array}$ \\
\hline
\end{tabular}


TABLE F.5. Summary of Electrostatic Precipitator First Costs

\begin{tabular}{|c|c|c|c|c|c|c|}
\hline Maker & $\begin{array}{l}\text { Unit, } \\
\$ K\end{array}$ & $\begin{array}{l}\text { Auxiliary } \\
\text { Equipment, } \\
\text { \$K }\end{array}$ & $\begin{array}{l}\text { Erection } \\
\text { Pad, Duct } \\
\text { etc., \$K }\end{array}$ & $\begin{array}{l}\text { Frejght, } \\
\$ K\end{array}$ & $\begin{array}{c}\text { ESP } \\
\text { Installation, } \\
\$ K \\
\end{array}$ & $\begin{array}{c}\text { Total, } \\
\$ K\end{array}$ \\
\hline $\begin{array}{l}\text { Vendor EE } \\
\text { Vendor } K \\
\text { Vendor KK } \\
\text { Vendor CC } \\
\text { Vendor EE } \\
\text { Vendor K } \\
\text { Vendor KK } \\
\text { Vendor CC }\end{array}$ & $\begin{array}{l}84.1 \\
120 \\
314.8 \\
209.4 \\
168.1 \\
240 \\
367 \\
418.8\end{array}$ & $\begin{array}{l}9.9 \\
9.9 \\
9.9 \\
0 \\
9.9 \\
9.9 \\
9.9 \\
0\end{array}$ & $\begin{array}{l}60.1 \\
60.1 \\
60.1 \\
63.8 \\
60.1 \\
60.1 \\
60.1 \\
63.8\end{array}$ & $\begin{array}{l}3.2 \\
1.2 \\
9.2 \\
4 \\
6.4 \\
2.4 \\
9.2 \\
8\end{array}$ & $\begin{array}{l}20 \\
20 \\
20 \\
80 \\
20 \\
20 \\
20 \\
157\end{array}$ & $\begin{array}{l}177 \\
211 \\
414 \\
357 \\
265 \\
332 \\
466 \\
648\end{array}$ \\
\hline
\end{tabular}

IABLE F.6. Erection Costs for Electrostatic Precipitators

\begin{tabular}{|c|c|c|}
\hline Item & $\begin{array}{l}\text { Vendor EE } \\
\text { Vendor } K \\
\text { Vendor KK }\end{array}$ & Vendor CC \\
\hline $\begin{array}{l}\text { Pad Size } \\
\text { Pad Cost, } \$ \\
\text { Compressor Shelter, } \$ \\
\text { Hopper shed, } \$ \\
\text { Seven-gauge ducts } \\
\text { and erection, } \$ \\
\text { Electrical, } \$ \\
\text { Pressure test, } \$ \\
\text { Drum scale, } \$ \\
\text { Flow controls, } \$\end{array}$ & $\begin{array}{c}22 \times 30 \mathrm{ft} \\
4,700 \\
2,800 \\
5,300 \\
20,900 \\
6,400 \\
1,900 \\
8,100 \\
10,000\end{array}$ & $\begin{array}{r}1600 \mathrm{ft}^{2} \\
11,200 \\
5,300 \\
20,900 \\
6,400 \\
1,900 \\
8,100 \\
10,000\end{array}$ \\
\hline Total & $\$ 60,100$ & $\$ 63,800$ \\
\hline
\end{tabular}

filters were assumed for the filter banks: first prefilter in bank 1 , second prefilter in bank 2, and HEPA filters in bank 3 . The filter replacement cost is the 20-year usage of disposable filters including new media, disposal, and all labor as estimated by FILTER. The total number of times a filter bank replacement may occur and the overall system efficiency were also estimated by FILTER and shown in the table. System pressure drop accounts for the building ductwork, the precipitator, and the maximum load on the filters. The precipitators have the lowest pressure drop of any of the devices investigated (about 0.5 to $1 \mathrm{in.} W \mathrm{G}$ ). The cost of the larger capacity fan was listed as needed and 
TABLE F.7. Electrostatic Precipitator Maintenance Estimates

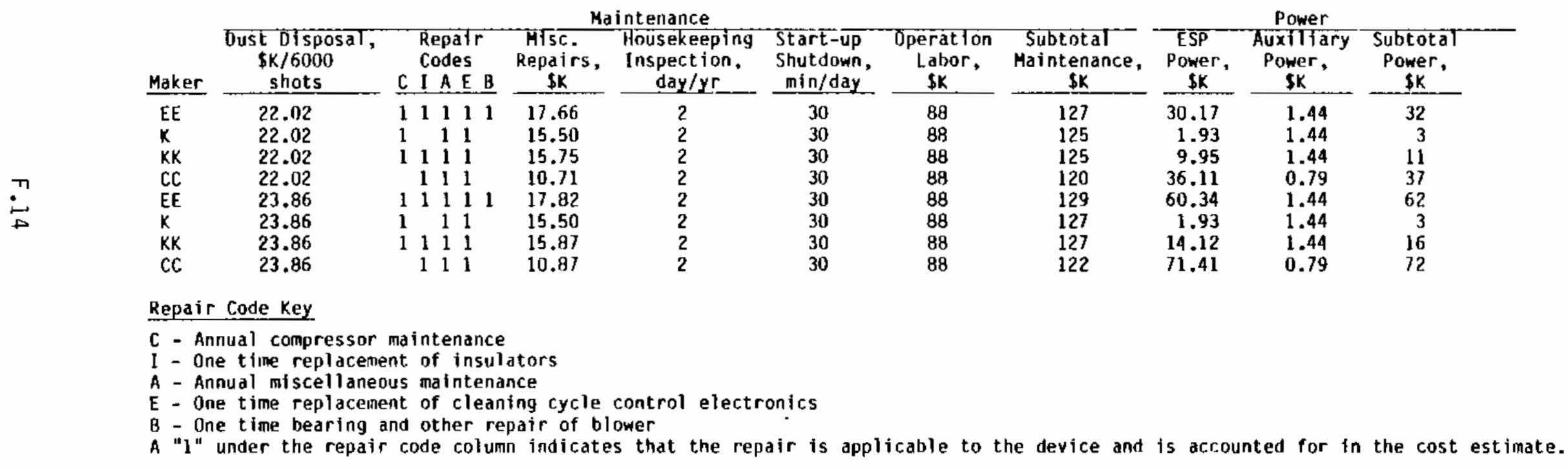


TABLE F.8. Twenty-Year Total Costs by Filter Bank Combination for Precipitators

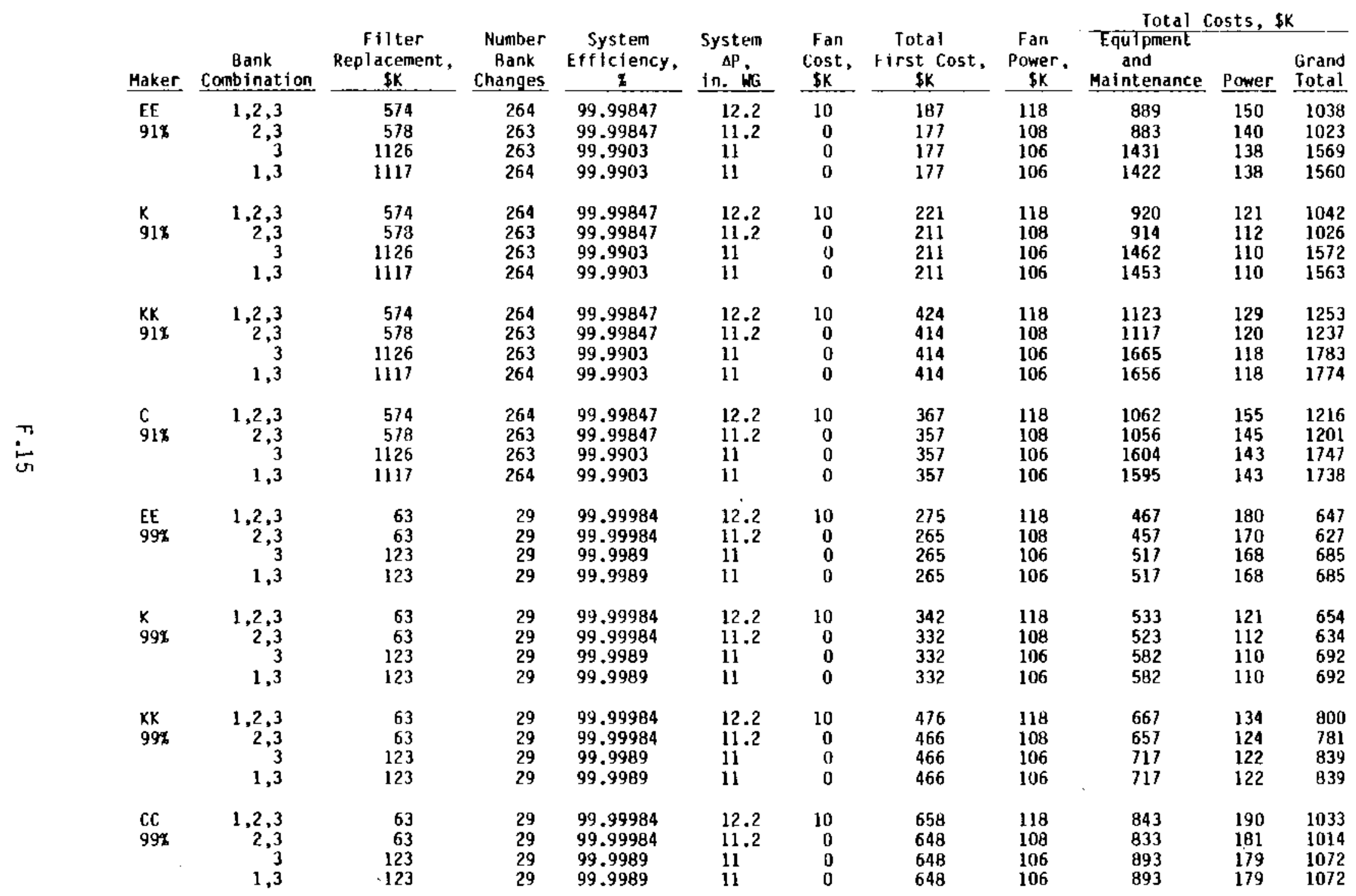


added to the first cost from Table F.5 to give an estimate of total initial investment. The 20-year fan power cost is 1 isted and added to the power cost of the precipitator and auxiliaries. The total costs excluding and including power are shown.

\section{REFERENCES}

Beachler, D. S., and J. A. Jahnke. 1981. APTI Course 413 Control of Particulate Emissions Student Manual. EPA 450/2-80-066, Northrop Services, Inc., Research Triangle Park, North Carolina.

Bethea, R. M. 1978. Air Pollution Control Technology, An Engineering Analysis Point of View. Van Norstrand Reinhold Company, New York, New York. 
APPENDIX G

CLEANABLE HIGH-EFFICIENCY FILTERS 
APPENDIX G

\section{CLEANABLE HIGH-EFFICIENCY FILTERS}

Two types of cleanable filters were recommended by vendors for this firing range application. Both employ media pleated into a rectangular frame similar to those in the existing system. The two types are denoted cleanable high efficiency filters and pulsed panel filters.

The cleanable high-efficiency filters (CHEF) described here use panels of pleated media in a frame similar in appearance to the existing HEPA filters. Two cleaning techniques are used--vacuuming and reverse air pulses. These cleaning techniques have been applied to filters with varying collection efficiencies. Both the vacuumed and reverse pulse-cleaned systems use glassfiber paper that has been coated to enhance the release of accumulated materials. Both systems use a similar housing as shown in Figure G.1. The reverse air pulse-cleaned system, represented at the top of Figure G.1, allows the material dislodged to fall by gravity into a hopper positioned under the filter units. This design would appear to suffer from the same problem that affects bag-type filters (reentrainment of the dislodged material in the airflow). The other system, represented at the left of Figure G.1, uses a vacuum nozzle passing beneath the filter to vacuum the accumulated material. The material vacuumed from the filter is removed by a combined cyclone and bag filter and is transmitted directly to the collection drum via a rotary valve. The vacuumed system also has provisions for a back-up cleanable HEPA filter.

A pulsed panel filter system, with a somewhat lower efficiency (ASHRAE 52-76 rating of $80 \%$ ) (ASHRAE 52-76 1976) than the first two systems, is shown in Figure G.2. The filter panels are $2 \mathrm{ft} \times 3 \mathrm{ft} \times 3 \mathrm{in}$. of cotton fibers. The accumulated material is displaced by a reverse air pulse and falls by gravity into a hopper positioned under the filters. As with all such units, reentrainment in the airflow is a concern. 


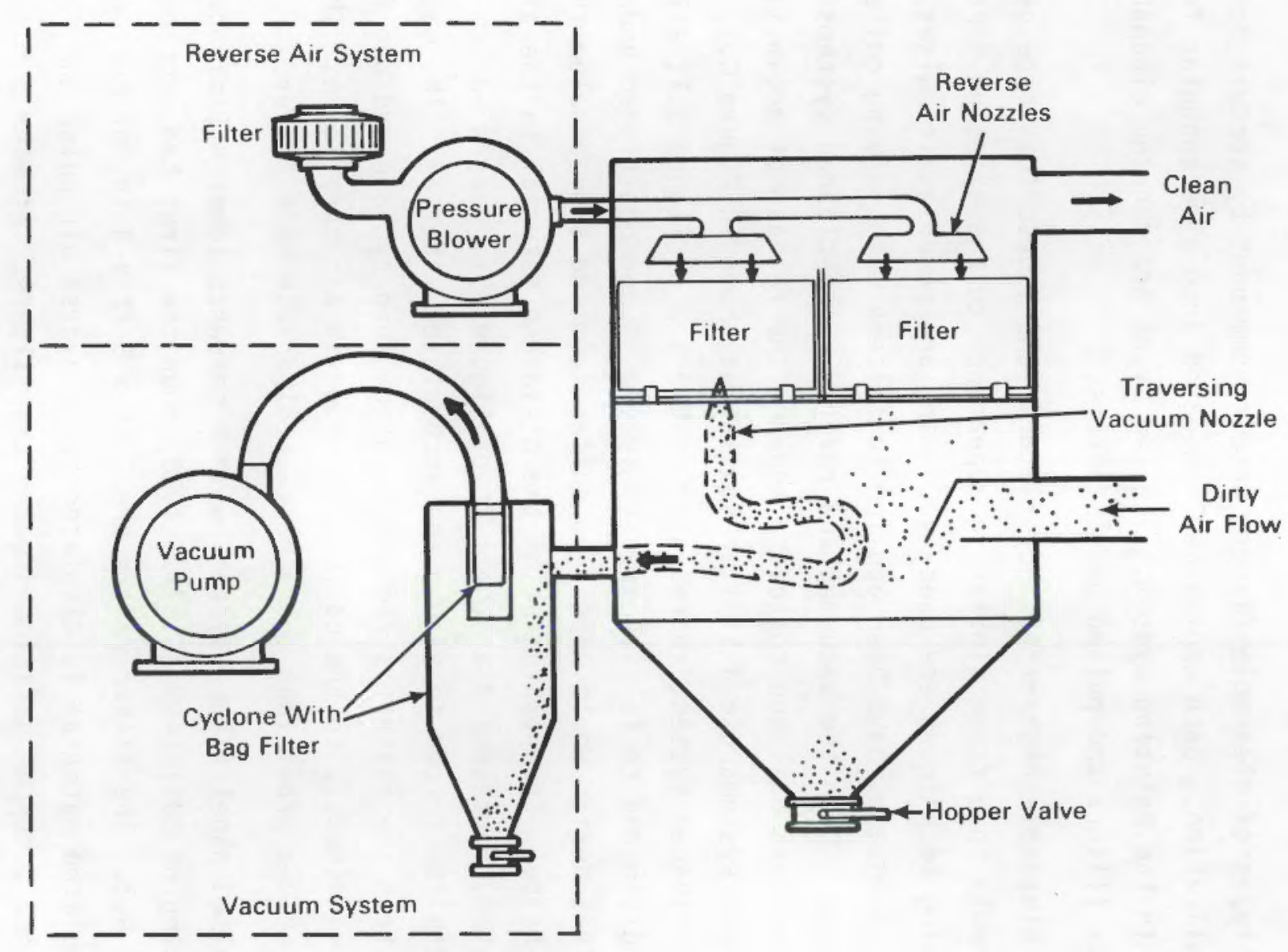

FIGURE G.1. Cleanable High-Efficiency Filter Showing Both Reverse Air (at top) and Vacuum Cleaning System Configurations (to left) 


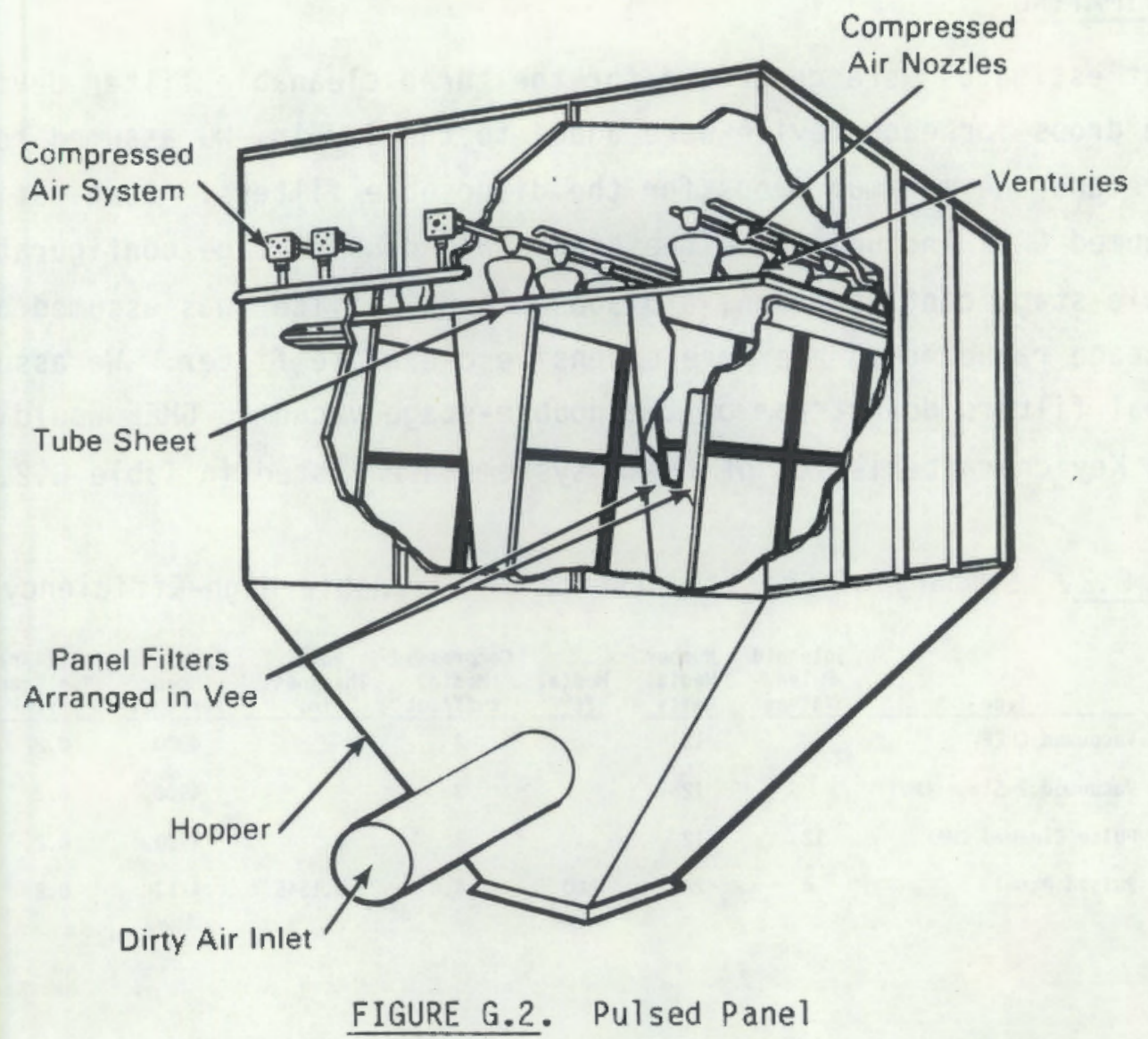

\section{COLLECTION EFFICIENCY}

Filter efficiency data for the pulsed panel device were obtained from the manufacturer. The HEPA filter data from Table B.1 were used for the other two units because no data were available from the vendors. Table G.1 lists the data used by the FILTER program.

TABLE G.1. Performance Input Data for Cleanable High-Efficiency Filters

\begin{tabular}{|c|c|c|c|c|c|c|c|c|}
\hline Filters & 0.1 & $0 . \overline{32}$ & $\frac{\text { Parti }}{1.0}$ & $\frac{\text { le Diamet }}{3.2}$ & $\frac{\mu \mathrm{m}}{10.0}$ & 32.0 & 100.0 & $\begin{array}{c}\text { Max. Unit } \\
\text { Pressure Drop, } \\
\text { In. MG } \\
\end{array}$ \\
\hline Vendor $S$ & 0.998 & 0.99968 & $0.9999 \star$ & 0.99999 * & $1.0^{\star}$ & $1.0^{*}$ & $1.0^{*}$ & $\begin{array}{l}\text { 11.0 Single Stage } \\
13.0 \text { Double Stage }\end{array}$ \\
\hline Vendor D & 0.998 & 0.99968 & $0.9999 *$ & $0.99999 *$ & $1.0^{*}$ & $1.0^{\star}$ & $1.0^{\star}$ & 15.0 \\
\hline Vendor $\gamma$ & $0.92 *$ & $0.93^{*}$ & 0.98 & 0.996 & 0.999 & $0.9999 *$ & $0.99999 *$ & 3.3 \\
\hline
\end{tabular}

* Indicates extrapolation of data 


\section{COST ESTIMATING}

Cost estimates were generated for the three cleanable filter devices. Pressure drops for each device were added to the $2.2 \mathrm{in}$. WG assumed for the structure and the maximum drops for the disposable filters. Cost estimates for the vacuumed CHEF included both the single and double-stage configurations. - For the double-stage configuration, a disposable HEPA filter was assumed as the second stage rather than the more expensive cleanable filter. We assumed that additional filters downstream of the double-stage vacuumed CHEF would be superfluous. Key characteristics of these systems are listed in Table f.2.

TABLE G.2. Summary of Characteristics of Cleanable High-Efficiency Filters

\begin{tabular}{|c|c|c|c|c|c|c|c|c|c|}
\hline Device & Type & $\begin{array}{l}\text { Solenotd } \\
\text { Puise } \\
\text { Valves } \\
\end{array}$ & $\begin{array}{l}\text { Mumber } \\
\text { Media } \\
\text { Units } \\
\end{array}$ & $\begin{array}{l}\text { Medza, } \\
\mathrm{ft}^{2}\end{array}$ & $\begin{array}{c}\text { Compressed } \\
\text { Media, } \\
\text { cuff/set } \\
\end{array}$ & $\begin{array}{c}\text { Hall } \\
\text { Thickness, } \\
\text { In. } \\
\end{array}$ & $\begin{array}{r}\text { Grams to } \\
\text { Hopper } \\
\text { Per shot }\end{array}$ & $\begin{array}{c}\text { Auxilliary } \\
\text { Run Frac.. } \\
\text { hr/hr } \\
\end{array}$ & $\begin{array}{c}\text { Auxilliary } \\
\text { Equi i pment, } \\
\text { hp }\end{array}$ \\
\hline Vendor S & Vacuumed CHEF & & 12 & & 3 & & 4900 & 0.2 & 28 \\
\hline Vendor $s$ & Vacuumed 2-Stage CHEF & & 12 & & 3 & & 4900 & 0.2 & 28 \\
\hline Vendor 0 & Pulse Cleaned CHEF & 12 & 12 & & 3 & & 4900 & 0.2 & 20 \\
\hline Vendor $Y$ & Pulsed Panel & 4 & 24 & 4800 & 4.8 & 0.1345 & 4713 & 0.2 & 3 \\
\hline
\end{tabular}

The unit costs for the CHEF devices include walkways, hopper valves, basic unit, controls, and bag-out doors as available. The unit cost for the pulsed panel seems low $(\$ 15 K)$ and there is some question as to whether hoppers, hopper valves, and air compressor are included. Fan and compressor costs were selected from Appendix $L$ as appropriate. Freight costs were not supplied by the vendors, but were values typical for similar equipment. The installation cost estimates were calculated from the estimates in Appendix $L$ as shown in Table G.3. The two-stage vacuumed CHEF required a smaller pad than the others because the existing filter house is not part of the system. The pulsed panel is designed to be located outdoors, so only shelters for the compressor and hopper dumping station were judged absolutely necessary. A larger shed may be desirable. 
TABLE G.3. Installation Costs For Cleanable High-efficiency Filters

\begin{tabular}{|c|c|c|c|c|}
\hline & Vacuur & CHEF & Reverse & \\
\hline Item & 1 Stage & 2 Stage & Pulse CHEF & Pulsed Panel \\
\hline $\begin{array}{l}\text { Additional } \\
\text { Pad } \times \mathrm{ft}\end{array}$ & $22 \times 30$ & $22 \times 15$ & $22 \times 30$ & $22 \times 30$ \\
\hline $\begin{array}{l}\quad \text { Cost, } \$ \\
\text { Pad } \\
\text { Hopper shed } \\
\text { Compressor shelter } \\
\text { Partial Shed }\end{array}$ & $\$ 4,700$ & $\$ 2,350$ & $\$ 4,700$ & $\begin{array}{r}\$ 4,700 \\
5,300 \\
2,800\end{array}$ \\
\hline Covering $\left(484 \mathrm{ft}^{2}\right)$ & $\$ 16,940$ & $\$ 16,940$ & $\$ 16,940$ & \\
\hline $\begin{array}{l}\text { Drum Scale } \\
\text { Flow Controls }\end{array}$ & $\begin{array}{r}8,100 \\
10,000\end{array}$ & $\begin{array}{r}8,100 \\
10,000\end{array}$ & $\begin{array}{r}8,100 \\
10,000\end{array}$ & $\begin{array}{r}8,100 \\
10,000\end{array}$ \\
\hline Pressure Test & 1,900 & 1,900 & 1,900 & 1,900 \\
\hline Electrical & 6,400 & 6,400 & 6,400 & 6,400 \\
\hline $\begin{array}{c}\text { Seven-yauge SS Ducts } \\
\text { plus Installation }\end{array}$ & 20,900 & 20,900 & 20,900 & 20,900 \\
\hline Total & $\$ 68,940$ & $\$ 66,590$ & $\$ 68,940$ & $\$ 60,100$ \\
\hline
\end{tabular}

A large shed covering the both CHEF units is probably desirable because each filter element has an access door and because of the complexity of the dust removal system. The reverse pulsed CHEF system required an external blower as auxiliary equipment; the cost of a $20 \mathrm{hp}$ compressor and air drier, $\$ 14.8 \mathrm{~K}$, was included in the initial costs to approximate that expense. Table G.4 summarizes the initial procurement costs of these systems excluding increased fan capacities.

TABLE G.4. First Costs of Cleanable High-Efficiency Filters Excluding Fan

\begin{tabular}{|c|c|c|c|c|c|c|}
\hline Device & Type & $\begin{array}{c}\text { Unit, } \\
\$ K\end{array}$ & $\begin{array}{c}\text { Auxiliary } \\
\text { Equipment, } \\
\$ K\end{array}$ & $\begin{array}{l}\text { Erection } \\
\text { Pad, Duct } \\
\text { etc., \$K } \\
\end{array}$ & $\begin{array}{c}\text { Freight, } \\
\$ K\end{array}$ & $\begin{array}{c}\text { Subtotal, } \\
\text { \$K }\end{array}$ \\
\hline Vendor $\mathrm{S}$ & Vacuumed CHEF & 88.6 & 0 & 68.9 & 2 & 160 \\
\hline Vendor $s$ & Vacuumed 2-Stage CHEF & 110 & 0 & 66.6 & 3 & 180 \\
\hline Vendor 0 & Pulse Cleaned CHEF & 66.8 & 14.8 & 68.9 & 1.2 & 152 \\
\hline Vendor Y & Pulsed Panel & 15 & 5.5 & 60.1 & 2 & 83 \\
\hline
\end{tabular}


Table G.5 shows the estimated 20-year maintenance costs for these systems, excluding the usage of the downstream disposable filters. The general method is outlined in the main report (pp. 12-23). Miscellaneous repairs for those items checked under the repair codes were estimated. The total estimated labor costs and compressor or blower power costs were calculated.

Table G.6 summarizes the system performance data and total costs by each combination of device and downstream disposable filter bank. Banks 1, 2, and 3 consist of the existing filter types. All of these systems exceeded the filter performance criterion except the pulsed panel followed by filter banks 1 and 3 or bank 3 alone, which at $99.9947 \%$ efficiency, may be satisfactory considering the uncertainties of the method. The table shows the cost of using the disposable filter banks for 20 yrs and the total number of times a filter bank will be changed. The total system pressure drop, the cost of the fan sized for that pressure drop and the 20-year cost of operating that fan were computed and are shown in the table. The total first cost for the fan and the equipment procurement and installation is also shown. The total of acquisition and maintenance costs, with and without power, is the overall cost of each system for the 20-year expected life.

For the single-stage vacuumed CHEF, the systems including banks 1 and 3 or just bank 3 were the least expensive in total cost because of reduced fan power requirements. When considering only equipment and maintenance, all of the combinations costs were about equal. For this system we recommend the combination with banks 2 and 3 because of the reduced cost of disposable filters, higher efficiency, and the additional protection the bank 2 affords the HEPA filters. The low-efficiency prefilters would be superfluous and would only add to the pressure drop. The ability of the existing filter housing to withstand the maximu fan suction, 21 in. WG, must be investigated.

For the pulsed panel system we recommend the configuration with banks 2 and 3 as the after-filters because the equipment and maintenance cost is about the same as for the lowest cost combination, and when power cost is included, it is the lowest cost. The efficiency criterion is better met with bank 2 in the systerm before the HEPA's. Bank 1 adds essentially no improvement in efficiency 
TABLE G.5. Maintenance Costs for Cleanable High-Efficiency Filters

\begin{tabular}{|c|c|c|c|c|c|c|c|c|c|c|c|c|c|c|}
\hline Moker & $\begin{array}{l}\text { Roplacement } \\
\text { Modlo, } \\
\text { sots/20 yr. }\end{array}$ & Modla & $\begin{array}{l}\text { plocement } \\
\underline{1} / 20 \text { yr }\end{array}$ & $\begin{array}{l}\text { Man-hr } \\
\text { Per Wodla } \\
\text { Chomge }\end{array}$ & $\begin{array}{l}\text { Modla } \\
\text { Change } \\
\text { Labor, KJ }\end{array}$ & $\begin{array}{l}\text { Modia } \\
\text { Disposal, } \\
\text { M/20 yr }\end{array}$ & $\begin{array}{l}\text { Dust } \\
\text { DI sposal. } \\
\text { s/onooo } \\
\text { shots } \\
\end{array}$ & $\begin{array}{c}\text { Repalr } \\
\text { Codes } \\
\text { C P A E B } \\
\end{array}$ & $\begin{array}{c}\text { Mf sc. } \\
\text { Repoirs. } \\
\end{array}$ & $\begin{array}{c}\text { Heu sexeopp I fg } \\
\text { In spect lon, } \\
\text { day/rr }\end{array}$ & $\begin{array}{l}\text { Start-up } \\
\text { Shutdoum, } \\
\text { miln/doy }\end{array}$ & $\begin{array}{c}\text { Operoting } \\
\text { Lobor. } \\
\end{array}$ & $\begin{array}{c}\text { Subtotal } \\
\text { Melntenance, } \\
\mathbf{H} \\
\end{array}$ & $\begin{array}{c}\text { Nuxillary } \\
\text { Pomer. } \\
\text { hp } \\
\end{array}$ \\
\hline Vendor $S$ & 1 & 700 & $\$ 8.40$ & 12 & 0.14 & 0.24 & 24.08 & 111 & 12.94 & 5 & 40 & 118.52 & 165 & 6.70 \\
\hline Vendor $S$ & 1 & 700 & 50,40 & 12 & 0.74 & 0.24 & 24.00 & 111 & 12.54 & 3 & 45 & 131.48 & 177 & 6.70 \\
\hline Vendor 0 & 2 & 300 & $\$ 12,00$ & $x$ & 3.35 & 0,36 & 24.00 & 1111 & 21.62 & 2.5 & 30 & 90.13 & 152 & 4.79 \\
\hline Ven ar $Y$ & 19 & 81 & 36.94 & 6 & 3.72 & 3.64 & 23.16 & 1111 & 18.86 & 3 & 30 & 92.61 & 179 & 0.12 \\
\hline
\end{tabular}

\section{Repair Code Key}

C - Annual compressor mintenance

1 - One tlmo roplacent of Insulators

A - Annual miscollaneous malntenarice

E - One timo replacement of clooning arcle control electronles

a - One time oring and other repalr of blower

A "1" uncer the rapale code colum Indicates that the repele ls appllcobie to

the dovice and is accounted for In the cost estimate. 
TABLE G.6. Twenty-Year Total Costs by Filter Bank Combination for Cleanable $\mathrm{High-efficiency} \mathrm{Filters}$

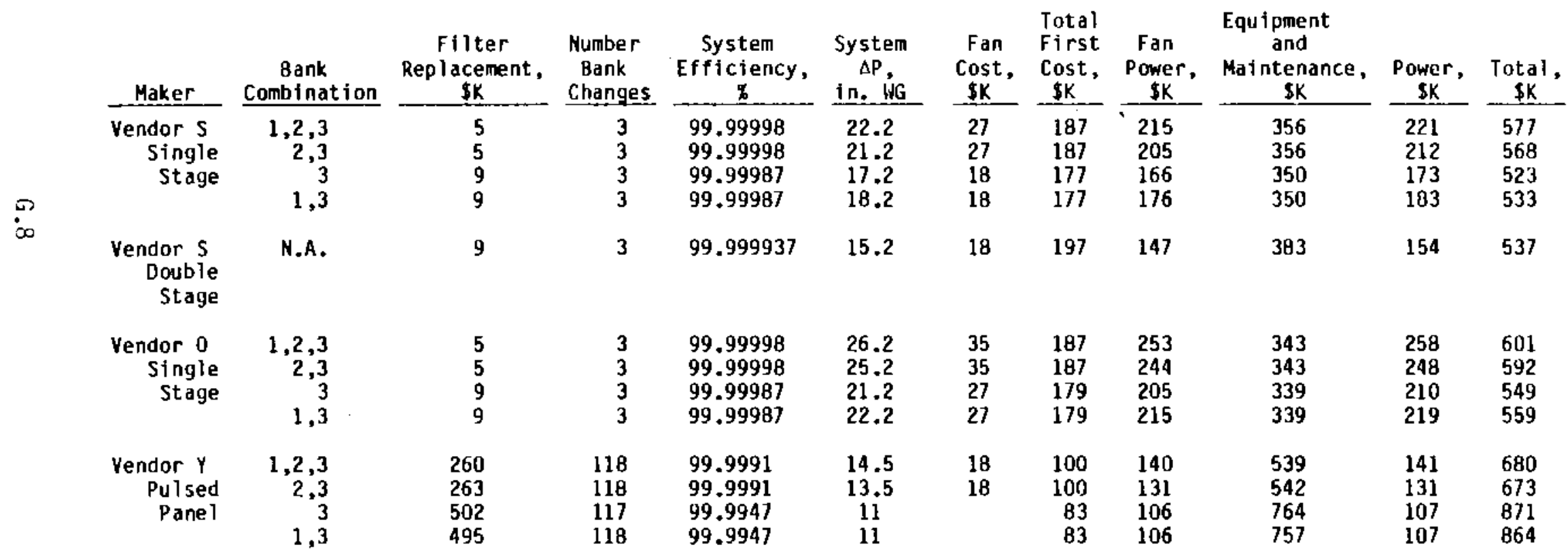


because the coarse particles it is designed to remove are al ready filtered by the pulsed panel. In general, we found this to be the case for all the cleanable primary control devices.

\section{REFERENCE}

ASHRAE 52-76. 1976. Method of Testing Air Cleaning Devices Used in General Ventilation for Removing Particulate Matter, American Society of Heating, Ventilating, and Air Conditioning Engineers, New York. 


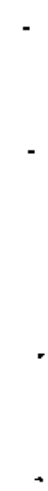


APPENDIX H

ROLLING FILTERS 
APPENDIX H

\section{ROLLING FILTERS}

Most of the rolling filters are in the prefilter category and many were not recommended by the vendors for this application because of the size of the airborne material anticipated. The only roll-type filter which appears to have promise is the peeled-roll filter. The design differs from conventional rolling filters because the airflow passes radially inward through all the layers of media wound on the clean media roll and then out through the end of the roll's core as shown in Figure H.1. The initial roll contains some 44 layers of media and high filtration efficiencies are obtainable with six to ten layers remaining. The unit sized for this application consists of 24 such rolls in a sheet metal housing. When all but the last few layers of media are used, the media is then completely rolled onto the take-up roll so that cleaner media is on the outside of the roll. To remove the media, the top of the housing is removed, a person enters the housing to unlatch the rolls and the rolls are hoisted with a small winch and boom.

In a conventional rolling filter the media are oriented vertically rather than horizontally as was the case for the peeled-roll unit. Instead of air filtration occurring through the rolled media, filtration is performed by the media stretched between the reels for most rolling filters. Only one layer of media is used for filtering. The stretched media is supported by a grill or screen. Generally, the device is inserted between two sections of duct so that the stretched media traverses the duct and the reels are outside the duct. For radiotoxic aerosols, the reels must also be located in an air-tight housing or inside the ductwork.

The media from both types of rolling filters could be disposed of in the same way. The media is removed from the reel core by separating the innermost layer from the core and sliding the media off the end. This procedure would require special containment. Media compaction to $15 \%$ of the original volume was assumed. If compaction proved not to be practical, the rolls could be disposed of in special containers, but probably at higher cost because of the 


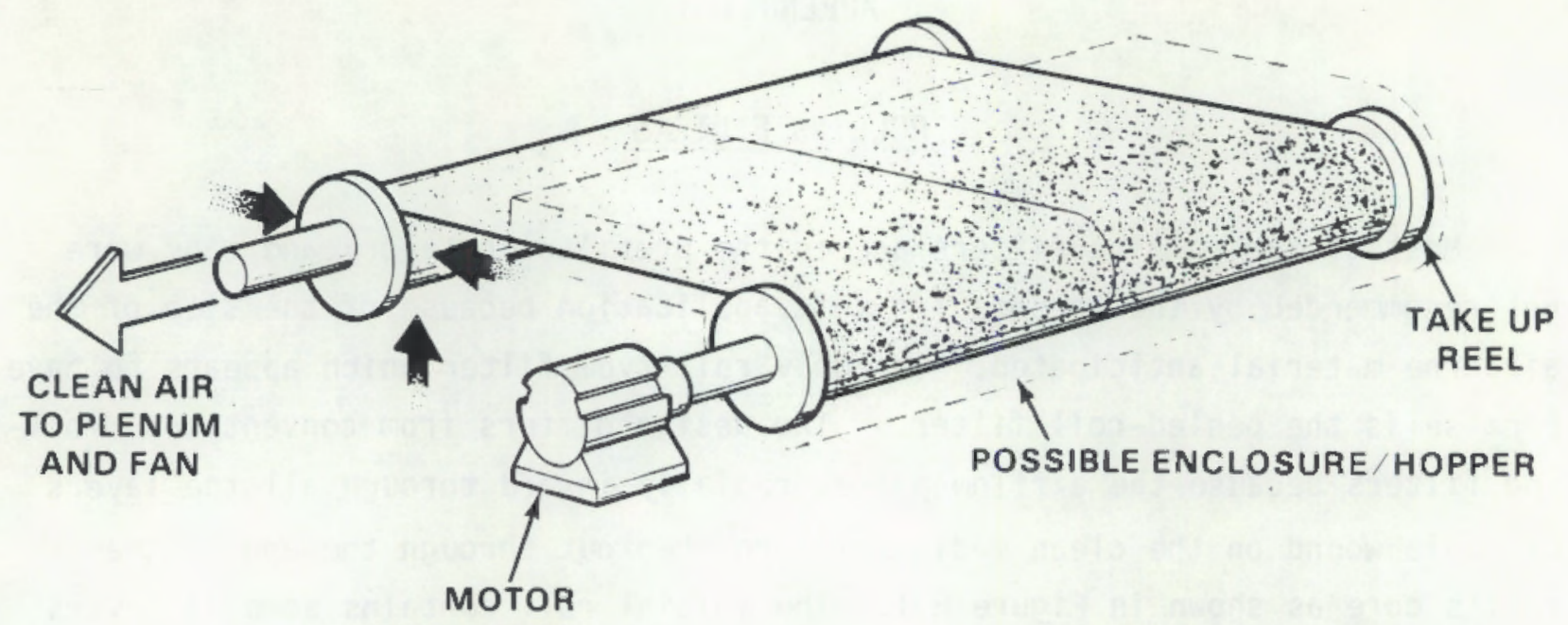

FIGURE H.1. Peeled-Roll Filter Concept

greater volume. The next section gives the total cost estimates for the peeled-roll and a typical rolling prefilter.

\section{COST ESTIMATING}

Conventional Rolling Filter

The cost of using this type of rolling filter was estimated using FILTER. The filter contains two rolls with $650 \mathrm{ft}^{2}$ of media of which $620 \mathrm{ft}^{2}$ were assumed useable. The maximum load of ASHRAE 52-76 (1976) test dust was given as $60 \mathrm{~g} / \mathrm{ft}^{2}$ at $1 \mathrm{in}$. WG pressure drop. The life load was then assumed to be about $620 \mathrm{ft}^{2} \times 60 \mathrm{~g} / \mathrm{ft}^{2}=37,200 \mathrm{~g}$. The media cost was given as $\$ 200 / \mathrm{roll}$ for a total of $2 \times \$ 200=\$ 400$ per replacement. The labor and disposal costs were added as shown in Table H.1.

TABLE H.1. Rolling Filter Media Replacement Cost

$$
\begin{aligned}
& \text { Media, } 2 \text { rol is } \\
& \text { Change-out, } 4 \text { man-hr } \\
& \text { Compaction, } 2 \text { man-hr } \\
& \text { Disposal cost }=0.15 \times \\
& 1 \mathrm{ft} \times 1 \text { ft } \times 10 \mathrm{ft}_{3}
\end{aligned}
$$$$
\text { Total }
$$

$$
\begin{array}{r}
\$ 400 \\
124 \\
62 \\
\\
38 \\
\$ 628
\end{array}
$$


The filter efficiency data were obtained from a graph furnished by the manufacturer; however, the method of determination was unknown. The efficiencies are listed in Table H.2.

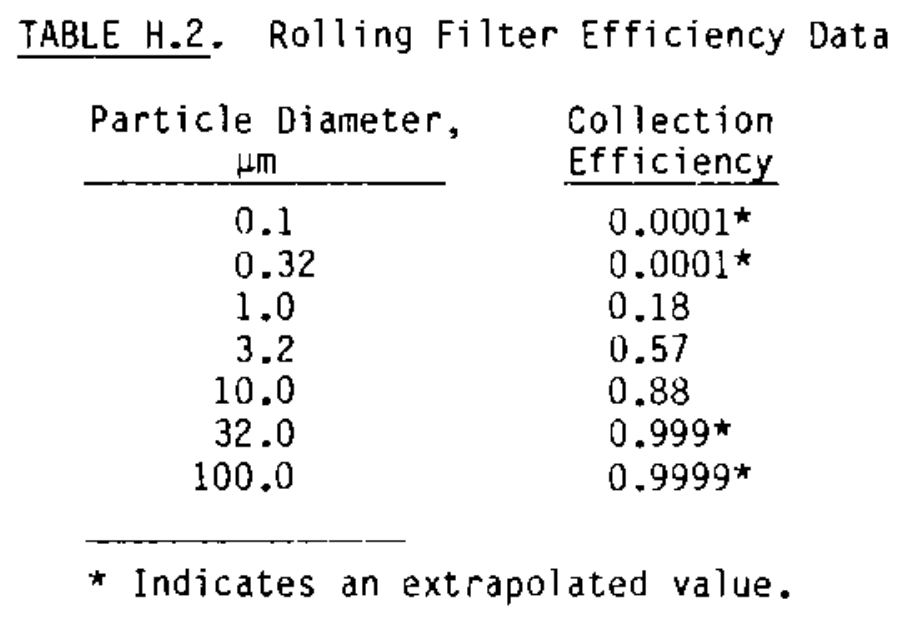

The results of the cost estimate for the conventional rolling filter are shown in Tables H.3 through H.6. The overall system efficiencies were about an order of magnitude lower than the performance criterion, but were the same as the existing system. The acquisition costs of the rolling filter were unavailable and were ignored; however, this device was not considered as a serious contender because the filter replacement costs were about the same as the existing system. If this ACS is to be considered, it would be used with all three of the existing filter banks downstream.

Peeled-Roll Filter

No fractional efficiency data were available for this device. Consequently, data from Table $\mathrm{H} .2$ were used because the type of media is similar. The assumed minimum number of media layers was ten. Equation (H.1) shows how the efficiency was calculated. The method for one particle size was to calculate the fractional penetration by subtracting the efficiency from one. The penetration is then multiplied by itself for each layer of media. The result is subtracted from one to calculate an efficiency again. This process was repeated for each particle size bracket and the results are listed in Table H.7. These efficiency values served as input to FILTER to calculate the cost of the different combinations of disposable filters. The FILTER results 


\section{TABLE H.3. Characteristics of Rolling Filters}

\begin{tabular}{|c|c|c|c|c|c|c|c|}
\hline Device Type & $\begin{array}{l}\text { Number } \\
\text { Media } \\
\text { Units } \\
\end{array}$ & $\begin{array}{l}\text { Media, } \\
\mathrm{ft}^{2} \\
\end{array}$ & $\begin{array}{c}\text { Compressed } \\
\text { Media, } \\
\mathrm{ft}^{3} / \text { set } \\
\end{array}$ & $\begin{array}{c}\text { Wall } \\
\text { Thickness, } \\
\text { in. } \\
\end{array}$ & $\begin{array}{l}\text { Grams to } \\
\text { Hopper } \\
\text { Per Shot }\end{array}$ & $\begin{array}{l}\text { Auxiliary } \\
\text { Run } \\
\text { Fraction, } \\
\text { hr/hr } \\
\end{array}$ & $\begin{array}{c}\text { Auxiliary } \\
\text { Equipment, } \\
\text { hp }\end{array}$ \\
\hline $\begin{array}{l}\text { Peeled Roll } \\
\text { Conventional Roll }\end{array}$ & $\begin{array}{r}24 \\
2\end{array}$ & $\begin{array}{l}28,800 \\
50\end{array}$ & 90 & 0.1046 & 0 & 0 & 0 \\
\hline
\end{tabular}

TABLE H.4. Rolling Filter Initial Costs

\begin{tabular}{|c|c|c|c|c|}
\hline Device Type & $\begin{array}{c}\text { Unit, } \\
\text { \$K }\end{array}$ & $\begin{array}{c}\text { Auxiliary } \\
\text { Equi pment, } \\
\text { \$K }\end{array}$ & $\begin{array}{l}\text { Erection } \\
\text { Pad, Duct } \\
\text { etc., } \$ K\end{array}$ & $\begin{array}{c}\text { Subtotal } \\
\$ K\end{array}$ \\
\hline Peeled Roll & 167 & 0 & 58.5 & 226 \\
\hline Conventional Roll & 3 & & 10 & 13 \\
\hline
\end{tabular}

TABLE H.5. Peeled-Roll Filter Installation Costs

\begin{tabular}{lr}
\multicolumn{1}{c}{ Item } & Cost, $\$$ \\
\hline Pad, 22 x $30 \mathrm{ft}$ & 4,700 \\
Airflow controls & 10,000 \\
Seven-gauge ducts & \\
plus installation & 20,900 \\
Pressure test & 1,900 \\
Electrical & 6,400 \\
Drum scale & 8,100 \\
Additional erection & 6,500 \\
& \\
Total & $\$ 58,500$
\end{tabular}


TABLE H.6. Maintenance Costs for Rolling Filter

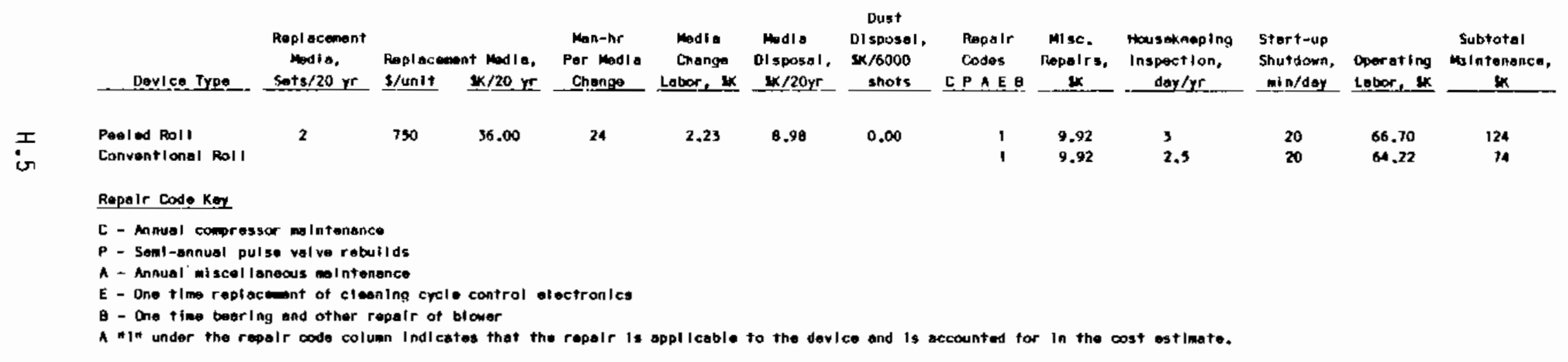




\section{TABLE H.7. Peeled-Roll Filter Fractional Efficiency}

\begin{tabular}{cl}
$\begin{array}{c}\text { Particle Diameter, } \\
\mu m\end{array}$ & $\begin{array}{l}\text { Collection } \\
\text { Efficiency }\end{array}$ \\
\hline 0.1 & 0.001 \\
0.32 & 0.001 \\
1.0 & 0.863 \\
3.2 & 0.99978 \\
10.0 & 0.999999999 \\
32.0 & 1.0 \\
100.0 & 1.0
\end{tabular}

showed efficiencies an order of magnitude lower than the criterion, even if the coarser size distributions were used. The cost of the disposable filters used in 20 years was about $75 \%$ that of the existing system.

$$
\text { Peeled-roll efficiency }=1-(1 \text { - Conventional roll efficiency })^{10}
$$

Table H.3 summarizes some of the characteristics of the two types of rolling filters. Table H.4 shows the initial cost of procuring the peeled-roll filter excluding the fan cost. The estimate for installation of the filter was calculated as shown in Table H.5 using estimates for the individual items from Appendix $K$. No extra auxiliary equipment was required to operate the system. Other than flow controls, no installation cost estimate was made for the conventional rolling filter because it was not considered as a serious option because of its low efficiency.

The peeled-roll filter is designed to operate at a high pressure drop, $10 \mathrm{in}$. WG, enabling the collection of large amounts of particles. For the dust loading expected at the range, the manufacturer estimated that media life is about 2000 shots, requiring two replacements in 20 years. The estimated media replacernent, change labor, and disposal costs are shown in Table H.6. These cost items for the conventional rolling filter were included in the estimates generated by FILTER, so they are not included in Table H.6. No repairs were estimated for the rolling filters, only the 16 man-hr/yr for annual maintenance and the indicated operating labor. 
Table H.8 shows various performance data and total costs for each combination of rolling filter and disposable filter bank combination. The existing filters were assumed for the filter banks; thus, banks 1,2 , and 3 consisted of first prefilter, second prefilter, and HEPA filters, respectively. The disposable filter replacement cost is the 20-year cost of new filters and disposal of used filters as estimated by FILTER. For the conventional rolling filter, the disposable filter cost also includes the costs of the roll media and its disposal. The total number of times a filter bank replacement may occur and the overall system filtration efficiency were also estimated by FILTER and are listed in Table H.8. System pressure drop accounts for the building ductwork, the rolling filter, and the maximum load on the disposable filters. The fan cost selection was based on the pressure drops listed. Total maintenance and acquisition costs for each combination are the sum of maintenance from Table H.3, first cost from Table H.2, disposable filter usage, and fan costs from Table H.4. Power costs are calculated and added to the equipment and maintenance cost.

The overall efficiencies shown in the table were not substantially better than the existing system and do not meet the performance criterion stated in Table 1 ( $99.9984 \%)$. The overall 20-year operating cost for the peeled-roll system was estimated to be about $75 \%$ of that of the existing system, which is a small improvment when compared to the systems with cleanable media. The estimated cost of using the conventional rolling filter was intermediate between the peeled-roll and the existing system. If the peeled-rol\} approach were implemented, all of the current disposable filters except bank 1 should also be used because that combination resulted in lowest cost for the system. All three of the disposable filter banks should be used downstream of the conventional roll. The rolling filters are not highly recomnended because of their high cost and low efficiency relative to other devices. 
TABLE H.8. Twenty-Year Cost of Rolling Filter

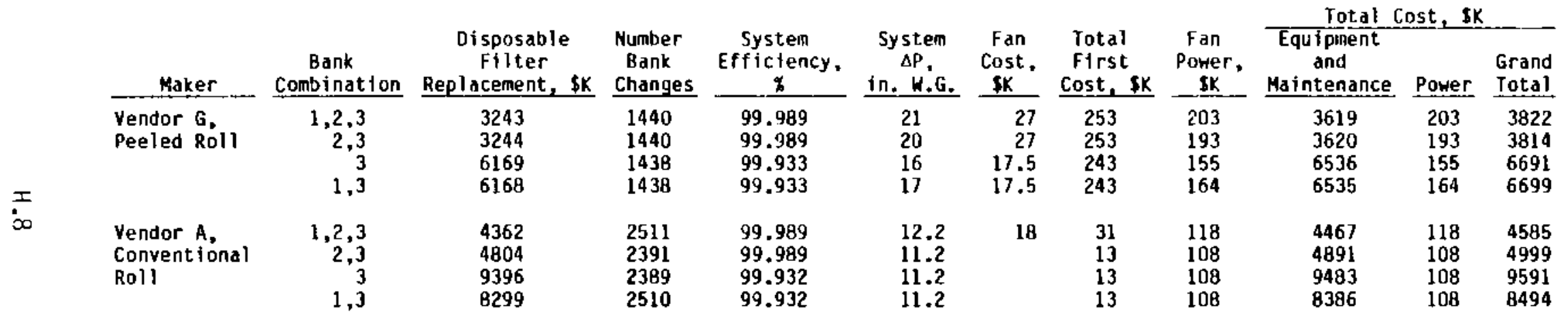


APPENDIX I

VANED INERTIAL SEPARATOR 
APPENDIX I

VANED INERTIAL SEPARATOR

\section{I.1 DESCRIPTION}

The vaned inertial separator is rated at $80 \%$ efficiency (ASHRAE 52-76). Ninety percent of the airflow is sharply turned through vanes while $10 \%$ of the airflow proceeds in a straight line. Because large particles cannot follow the rapid change in direction through the vanes, they follow the $10 \%$ airflow in a straight line. The $10 \%$ airflow, now more heavily laden with particles, passes through a pulsed-panel unit that removes $80 \%$ to $90 \%$ of the particles. The $90 \%$ airflow from the vaned inertial separator and the exhaust from the pulsed panel are combined and passed through a second pulsed panel. The airflow through the vaned inertial separator/pulsed-panel combination is diagrammed in Figure I.1. A section of a vaned inertial separator is shown in Figure I.2. The vaned inertial separator would be enclosed in a sheet metal housing.

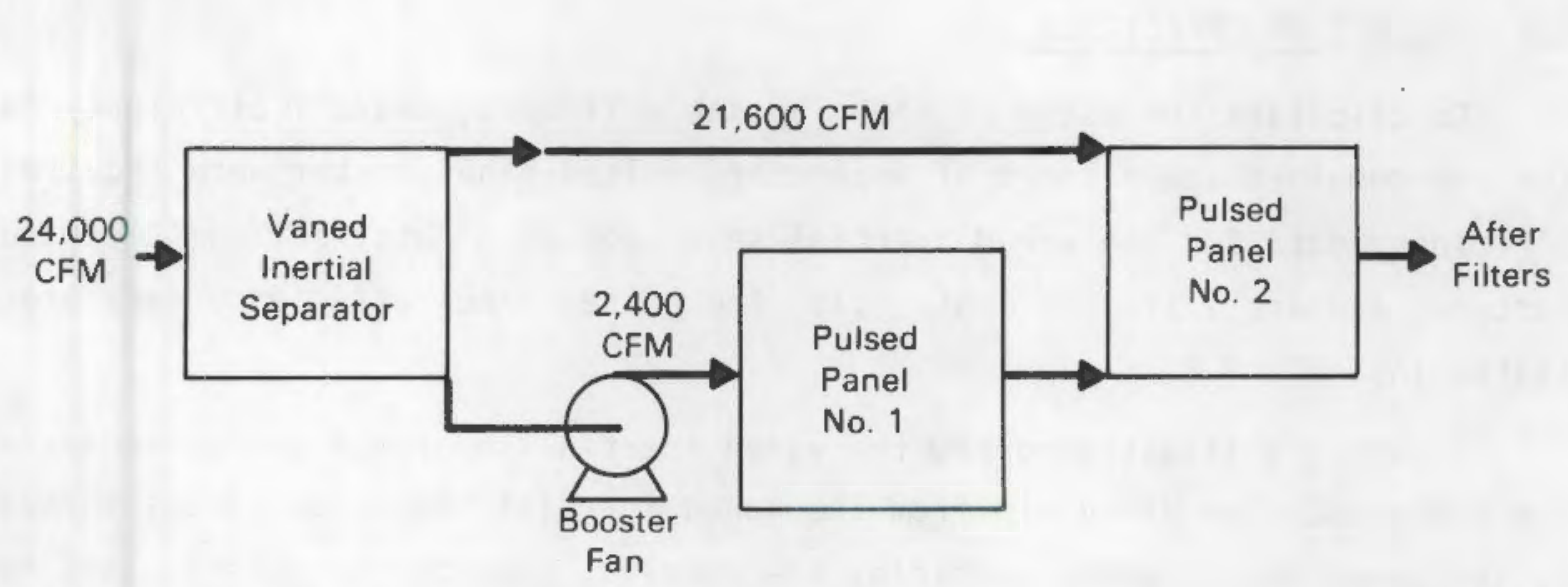

FIGURE 1.1. Vaned Inertial Separator Equipment Arrangement 

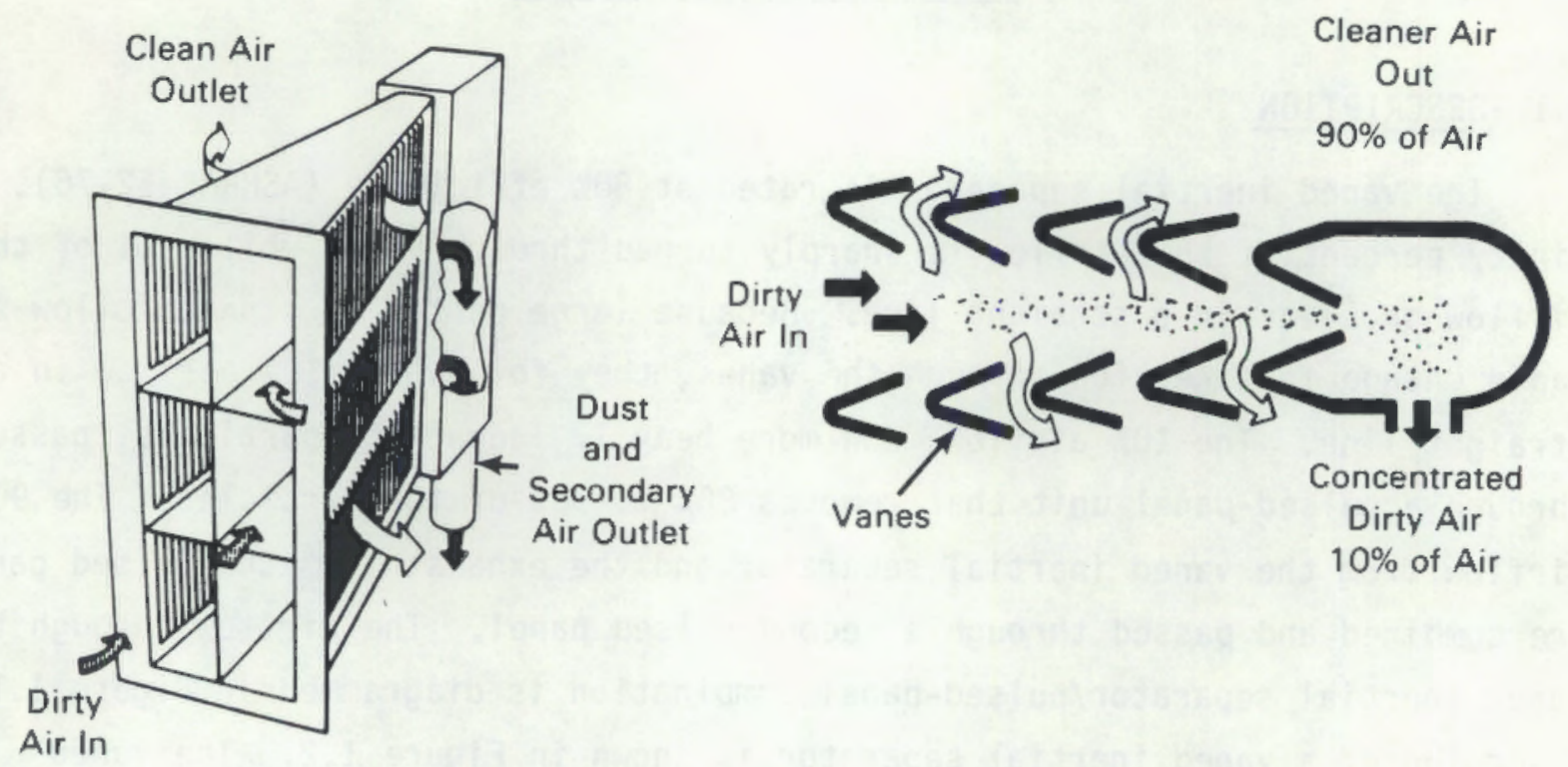

FIGURE I.2. Vaned Inertial Separator

\section{I.2 COLLECTION EFFICIENCY}

To calculate the usage of the disposable filters, overall efficiency data for the combined vaned inertial separator--pulsed-panel system were required. Efficiency data for the vaned inertial separator were obtained from the manufacturer and are listed in Table I.1. The pulsed-panel efficiency data are listed in Table G.2.

Figure I.1 illustrated how the vaned inertial separator and pulsed-panel are combined. The dirty air from the vaned inertial separator passes through pulsed-panel No. 1, where particles are removed, and then to pulsed-panel No. 2 for further particle removal. The clean air from the vaned inertial separator goes directly to pulsed-panel No. 2 for particle removal. The size distribution from pulsed-panel No. 2 is needed to calculate the usage of the disposable filters. The dirty airflow from the vaned inertial separator is about $10 \%$ of the inlet airflow; thus, pulsed-panel No. 1 was sized for only 2400 acfm. 
TABLE I.1. Fractional Filter Efficiency Data for Vaned Inertial Separator

Particle

Di ameter, $\mu \mathrm{m}$

0.1

Collection Efficiency

0.32

$0.18^{*}$

1.0

$0.18 *$

3.2

$0.30^{*}$

10.0

0.67

32.0

0.985

100.0

0.999 *

$0.9999 *$

* Indicates an extrapolated value

Table I.2 shows the calculation of the combined efficiency for the system shown in Figure 1.1. The initial distribution of aerosol mass is that of size Distribution No. 3 from Table 5 . The mass of particles in each size bracket passed to pulsed-panel No. 1 was calculated by multiplying the initial mass distribution column by the vaned inertial separator efficiency column and the balance of the particles go on to pulsed-panel No. 2. The mass collected in pulsed-panel No. 1 was obtained by multiplying the quantity from the vaned inertial separator by the pulsed-panel efficiency values, and the uncollected fractions are passed as additional input to pulsed-panel No. 2. The combined inputs to pulsed-panel No. 2 are multiplied by the pulsed-panel efficiency values to compute the amounts collected from which the overall fractional efficiencies for the combined system were computed. The total efficiency for the original aerosol was estimated to be about $97 \%$, which was only slightly better than the efficiency of a single pulsed-panel alone (96\%). The overall fractional efficiencies for these combined devices was used as an input to FILTER to compute the usage of the combinations of disposable after-filters. Thus, for such a fine aerosol size distribution, the vaned inertial separator accomplishes little; however, it would serve as a good barrier to particles in the size range where cyclones are also effective, but with a lower pressure drop than the cyclones. 
IABLE 1.2. Calculation of Combined Vaned Inertial Separator and Pulsed-Panel Efficiency

\begin{tabular}{|c|c|c|c|c|c|}
\hline $\begin{array}{c}\text { Size } \\
\text { Bracket } \\
\end{array}$ & $\begin{array}{l}\text { Inlet } \\
\text { Mass Dis- } \\
\text { tribution, } \\
\mathrm{g} \\
\end{array}$ & $\begin{array}{c}\text { Vaned } \\
\text { Inertial } \\
\text { Separator } \\
\text { Effjciency, } \% \\
\end{array}$ & $\begin{array}{c}\text { Grams to } \\
\text { Pulsed- } \\
\text { Panel No. } 1 \\
\end{array}$ & $\begin{array}{c}\text { Grams to } \\
\text { Pul sed- } \\
\text { Panel No. } 2 \\
\end{array}$ & $\begin{array}{c}\text { Pulsed- } \\
\text { Panel } \\
\text { Efficiency, } \%\end{array}$ \\
\hline 1 & 1519 & 0.18 & $2.73 E+02$ & $1.25 E+03$ & 0.92 \\
\hline 2 & 686 & 0.18 & $1.23 E+02$ & $5.63 E+02$ & 0.93 \\
\hline 3 & 735 & 0.3 & $2.21 E+02$ & $5.15 E+02$ & 0.98 \\
\hline 4 & 637 & 0.67 & $4.27 E+02$ & $2.10 E+02$ & 0.996 \\
\hline 5 & 539 & 0.985 & $5.31 E+02$ & $8.09 E+00$ & 0.999 \\
\hline 6 & 343 & 0.999 & $3.43 \mathrm{E}+02$ & $3.43 E-01$ & 0.9999 \\
\hline 7 & 441 & 0.9999 & $4.41 E+02$ & $4.41 \mathrm{E}-02$ & 0.99999 \\
\hline Total & 4900 & & $2.36 \mathrm{E}+03$ & $2.54 E+03$ & \\
\hline
\end{tabular}

Pulsed-Panel No. 1 Pulsed-Panel No. 2

$\begin{array}{cccccccc}\begin{array}{c}\text { Size } \\ \text { Bracket }\end{array} & \begin{array}{c}\text { Grams } \\ \text { Collected }\end{array} & \begin{array}{c}\text { Grams } \\ \text { Penetrated }\end{array} & \begin{array}{c}\text { Total } \\ \text { Renams In }\end{array} & \begin{array}{c}\text { Grams } \\ \text { Collected }\end{array} & \begin{array}{c}\text { Grams To } \\ \text { Disposable } \\ \text { Filters }\end{array} & \begin{array}{c}\text { Combined } \\ \text { System } \\ \text { Efficiency, }\end{array} \\ 2 & 1.15 E+02 & 2.19 E+01 & & 1.27 E+03 & 1.17 E+03 & 1.01 E+02 & 0.933248 \\ 3 & 2.16 E+02 & 4.41 E+00 & 5.19 E+02 & 5.09 E+02 & 1.04 E+01 & 0.98588 \\ 4 & 4.25 E+02 & 1.71 E+00 & 2.12 E+02 & 2.11 E+02 & 8.48 E-01 & 0.99866928 \\ 5 & 5.30 E+02 & 5.31 E-01 & 8.62 E+00 & 8.61 E+00 & 8.62 E-03 & 0.99998401 \\ 6 & 3.43 E+02 & 3.43 E-02 & 3.77 E-01 & 3.77 E-01 & 3.77 E-05 & 0.99999989 \\ 7 & 4.41 E+02 & 4.41 E-03 & 4.85 E-02 & 4.85 E-02 & 4.85 E-07 & 0.99999999 \\ \text { Total } & 2.32 E+03 & 3.72 E+01 & 2.58 E+03 & 2.43 E+03 & 1.53 E+02 & 0.96885464\end{array}$




\section{COST ESTIMATING}

Table 1.3 contains a descriptive summary of the characteristics of the vaned inertial separator/pulsed-panel system. Table I.4 shows the initial acquisition costs. To estimate the acquisition cost for the vaned inertial separator system we assumed that the installation cost was about the same as for the pulsed-panel alone (Table G.4). Table I.5 shows the estimate for 20-year maintenance of the system excluding the cost of downstream disposable filters. The estimating method is described in the main report ( $p p, 12-23$ ). The pulsed-panel media life was assumed to be 1 year, and the total number of filter units would be 28 for both units No. 1 and 2 together. Media compaction was the same as for the pulsed-panel alone. The repair items considered were compressor maintenance, pulse valve rebuilds, miscellaneous annual maintenance, and the replacement of filters.

Table 1.6 shows various performance data and total costs for the vaned inertial separator system and each disposable filter bank combination. The existing filters were assumed for the filter banks; thus, banks 1, 2, and 3 consisted of the first prefilter, second prefilter, and high-efficiency particulate air (HEPA) filters, respectively. The disposable filter replacement cost is the 20-year cost of new filters and disposal of used filters as estimated by FILTER. The total number of times a filter bank replacement may occur and the overall system filtration efficiency was also estimated by FILTER and listed in the table. System pressure drop accounts for the building duct work, the vaned inertial separator system, and the maximum load on the disposable filters. However, the use of pulsed panel No. 1 requires a booster fan between it and pulsed panel No. 2. The pressure drops across the vaned inertial separator and pulsed panel No. 2 were taken as 1.1 and 3.3 , respectively, for a total of $4.4 \mathrm{in}$. WG. This was added to the total for the building, duct work, and after filters to determine the price of the main fan. The booster fan would also see a pressure drop of about $4.4 \mathrm{in}$. $W G$ and $\$ 8 \mathrm{~K}$ was the assumed price of the booster fan. The pressure drops listed in the table were estimated for the overall system with $4.4 \mathrm{in}$. WG added so that power costs would be estimated for both fans. Total maintenance and acquisition costs for each 
TABLE 1.3. Vaned Inertial Separator Descriptive Summary

\begin{tabular}{|c|c|c|c|c|c|c|c|c|}
\hline $\begin{array}{l}\text { Media } \\
\text { Access }\end{array}$ & $\begin{array}{l}\text { Solenoid } \\
\text { Pulse } \\
\text { Valves } \\
\end{array}$ & $\begin{array}{l}\text { Number } \\
\text { Medi a } \\
\text { Untts } \\
\end{array}$ & $\begin{array}{c}\text { Medjaa, } \\
\mathrm{ft}^{2}\end{array}$ & $\begin{array}{c}\text { Compressed } \\
\text { Media, } \\
\mathrm{ft}^{3} / \text { set }\end{array}$ & $\begin{array}{c}\text { Wall } \\
\text { Thickness, } \\
\text { in. }\end{array}$ & $\begin{array}{l}\text { Grams to } \\
\text { Hopper } \\
\text { Per Shot }\end{array}$ & $\begin{array}{c}\text { Auxilfary } \\
\text { Run Fraction, } \\
\text { hr/hr }\end{array}$ & $\begin{array}{c}\text { Auxiliary } \\
\text { Equipment, } \\
\text { hp }\end{array}$ \\
\hline $\begin{array}{l}\text { opper } \\
\text { atch }\end{array}$ & 5 & 28 & 5600 & 5.6 & 0.1196 & 4747 & 0.2 & 3 \\
\hline
\end{tabular}

TABLE I.4. Vaned Inertial Separator Initial Costs, Excluding Fan

$\frac{\begin{array}{c}\text { Unit, } \\ \$ K\end{array}}{25} \frac{\begin{array}{c}\text { Auxiliary } \\ \text { Equipment, } \\ \text { \$K }\end{array}}{5.5} \frac{\begin{array}{c}\text { Erection } \\ \text { Pad, Duct, } \\ \text { etc., } \$ K\end{array}}{60.1} \frac{\begin{array}{c}\text { Freight, } \\ \text { \$K }\end{array}}{3} \frac{\begin{array}{c}\text { Subtotal, } \\ \$ K\end{array}}{94}$

IABLE 1.5. Vaned Inertial Separator Twenty-Year Maintenance

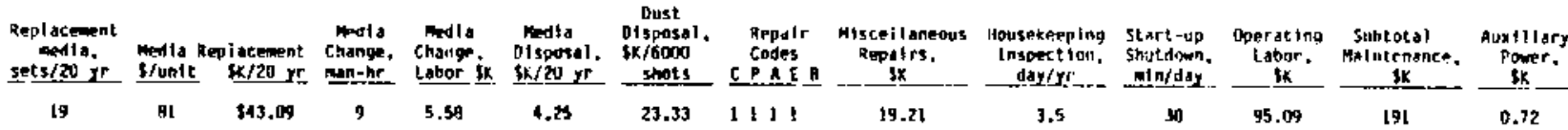

Repair Code Xey

c. - Amual empresgor maintenance

- Seal-anmal pulse valve rebultds

- The tian repluctant of cleontong

crele controi electronics

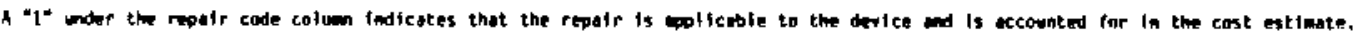

\section{TABLE I.6. Twenty-Year Total Costs by Filter Bank Combination for Vaned Inertial Separator and Pulsed-Panel System}

\begin{tabular}{|c|c|c|c|c|c|c|c|c|c|c|}
\hline $\begin{array}{c}\text { Bank } \\
\text { Combination }\end{array}$ & $\begin{array}{c}\text { Disposable } \\
\text { Filter } \\
\text { Replacement, sk }\end{array}$ & $\begin{array}{l}\text { Nuniber } \\
\text { Bank } \\
\text { Changes } \\
\end{array}$ & 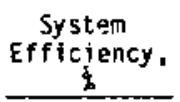 & $\begin{array}{l}\text { System } \\
\Delta \mathrm{P}, \\
\text { in. Win }\end{array}$ & $\begin{array}{l}\text { Fan } \\
\text { Cost, } \\
\text { \$K }\end{array}$ & $\begin{array}{l}\text { Total } \\
\text { First, } \\
\text { Cost \$K }\end{array}$ & $\begin{array}{c}\text { Fati } \\
\text { Power, } \\
\text { \$K }\end{array}$ & $\begin{array}{l}\text { Equipment and } \\
\text { Ma intenance, } \$ \mathrm{~K}\end{array}$ & $\begin{array}{l}\text { Power, } \\
\$ \mathrm{~K}\end{array}$ & $\begin{array}{c}\text { Total, } \\
\text { EK }\end{array}$ \\
\hline $\begin{array}{r}1,2,3 \\
2,3 \\
3 \\
1,3\end{array}$ & $\begin{array}{l}214 \\
215 \\
409 \\
407\end{array}$ & $\begin{array}{l}96 \\
96 \\
96 \\
96\end{array}$ & $\begin{array}{l}99.9993 \\
99.9993 \\
99.9956 \\
99.9956\end{array}$ & $\begin{array}{l}19.6 \\
18.6 \\
14.6 \\
15.6\end{array}$ & $\begin{array}{l}26 \\
26 \\
10 \\
18\end{array}$ & $\begin{array}{l}119 \\
119 \\
104 \\
112\end{array}$ & $\begin{array}{l}190 \\
180 \\
141 \\
151\end{array}$ & $\begin{array}{l}524 \\
525 \\
703 \\
709\end{array}$ & $\begin{array}{l}190 \\
181 \\
142 \\
152\end{array}$ & $\begin{array}{l}714 \\
705 \\
845 \\
861\end{array}$ \\
\hline
\end{tabular}


combination are the sum of maintenance from Table I.5, first cost from Table 1.4, disposable filter usage, and fan costs from Table 1.6. Power costs are calculated and added to the equipment and maintenance cost.

The equipment and maintenance costs for using this system were slightly lower than for the pulsed panel alone; however, when power consumption is included, the vaned inertial separator system was slightly more expensive than the pulsed-panel alone. If this approach were to be implemented, the afterfilters should include the second prefilter and the HEPA banks because this combination yielded the lowest cost. 


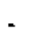


APPENDIX J

CHARGED WATER MIST 


\title{
APPENDIX J
}

\section{CHARGED WATER MIST}

\begin{abstract}
A local-dust-control unit was uncovered during this study. The unit supposedly generates a fine charged mist that evaporates, leaving charged particles in the air. These particles attract and agglomerate with airborne material producing larger particles that deposit locally by gravity. Such a unit(s) could be positioned in the target bay in a shielded position. Once the initial blast effects have passed, the units could be started and may enhance the rapid settling of the airborne material locally. Because the efficacy of the device is uncertain and a pilot study is needed, it has not been considered further in this report.
\end{abstract}




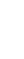


APPENDIX K

INSTALLATION COST ESTIMATES 
APPENDIX K

\section{INSTALLATION COST ESTIMATES}

A few of the air cleaning equipment vendors contacted were willing to supply budget estimates for the turnkey installation of their equipment and adaptation to the existing ductwork and filter house; however, most vendors were unable to do so, either because of the time involved or the fact that they did not do turnkey work. To put the 20-year life cost estimates for the different devices on a common footing, it was decided to obtain authoritative installation estimates from an outside licensed engineering firm. Kaiser Engineers Hanford Company, Richland, Washington, was requested to supply estimates for concrete pads; air compressors; fans; airflow controls; electrical service; pressure testing; freight to jobsite; fabrication and installation of ductwork; erection of new air cleaning equipment; relocation of the existing filter house; sheds to cover compressors, hopper dumping stations, or the entire pad; and drum-handling equipment (e.g., dollies and scales). Labor and material costs were based on Mossman's (1982) cost index for Baltimore. Table $k .1$ summarizes the totals for each item.

The concrete pad estimates included labor and material for excavating, backfilling, forming, concrete, finishing, rebar (100 1b/yd ${ }^{3}$ ), form stripping, and curing. The estimates for the air compressors included receiver tank, auto trap on tank, air-cooled compressor, low-oil-level switch, enclosed motor, dual controls, heavy duty filter, dryer, piping, heat tracing, and insulation.

The estimates for sheds (Table K.1, items 8 and 9) included metal walls, lights, heat, ventilation, electrical service, insulation, windows, side doors, overhead doors, water, and sewer. The basic cost estimate was $\$ 35 / \mathrm{ft}^{2}$ of floor space and for a wall height up to $12 \mathrm{ft}$. For wall heights over $12 \mathrm{ft}, \$ 8.50$ was added for each additional foot in wall height per foot of building perimeter. The hopper dump shed was based on an area of $150 \mathrm{ft}^{2}$. This shed could be employed where a total system building was not used and could be built around the botton of an ESP, baghouse, or other device with sufficient 
TABLE K.1. Cost Estimate Summary for Installation, Fans and Auxiliary Equipment

\begin{tabular}{|c|c|c|}
\hline Item & Description & Estimated Cost, \$ \\
\hline 1. & Concrete pad, $22 \times 30 \mathrm{ft}$ & 4,700 \\
\hline 2. & Concrete pad, $16 \times 100 \mathrm{ft}$ & 11,200 \\
\hline 3. & Air compressor, 8.5 scfm 100 psig, $3 \mathrm{hp}$ & 5,500 \\
\hline 4. & Air compressor, $15.3 \mathrm{scfm}$ o $100 \mathrm{psig}, 5 \mathrm{hp}$ & 5,600 \\
\hline 5. & Air compressor, 32 scfm 0100 psig, $7 \mathrm{hp}$ & 9,900 \\
\hline 6. & Air compressor, 39 scfm o 100 psig, 10 ho & 10,000 \\
\hline 7. & Air compressor, $77.7 \mathrm{scfm} 100 \mathrm{psig,} 20 \mathrm{hp}$ & 14,800 \\
\hline 8. & Hopper dump shed & $5 ; 300$ \\
\hline 9. & Shed cover for pad & 19,400 \\
\hline 10. & Shed for air compressor & 2,800 \\
\hline 11. & Orum dollies, each & 40 \\
\hline 12. & Orum scale, low ramp, digital & 8,100 \\
\hline 13. & Drum scale, warehouse platform & 4,100 \\
\hline 14. & Single inlet Fan, 23 in. WG vac., 110 hp & 27,000 \\
\hline 15. & Single inlet Fan, 17 in. WG vac., 100 hp & 17,500 \\
\hline 16. & Single inlet Fan, 13 in. WG vac., $75 \mathrm{hp}$ & 17,000 \\
\hline 17 & Upgrade existing Fan To $13 \mathrm{in}$. WG vac. $75 \mathrm{hp}$ & 10,000 \\
\hline 18. & Same fan cap. as \#14. in existing housing & 19,200 \\
\hline 19. & New fan housing for existing fan & 6,000 \\
\hline 20. & Fan motor speed and afrflow controller, $75 \mathrm{hp}$ & 12,800 \\
\hline 21. & Fan motor speed and airflow controller, 100 hp & 15,100 \\
\hline 22 & Fan motor speed and airflow controller, $125 \mathrm{hp}$ & 17,900 \\
\hline 23 & Fan motor speed and airflow controlier, $150 \mathrm{hp}$ & 20,800 \\
\hline 24 & Install new system, 16 gauge galvanized ducts & 11,400 \\
\hline 25 & Install new system, 7 gauge carbon steel ducts & 20,900 \\
\hline 26 & Install new system, 7 gauge stainless steel ducts & 26,900 \\
\hline 27 & Pressure test ductwork to filter house & 1,900 \\
\hline 28 & Move electrical services, hookups & 6,400 \\
\hline 29 & Freight rates (sample, 50,000 lb, Chicago to Abe & 1,200 \\
\hline 7 & Vortex dampers, electrical airflow controls & 10,000 \\
\hline
\end{tabular}

clearance. The shed would permit dumping of the hopper and changing and filling of the drum under all weather conditions. The estimate for a metal shed totally enclosing the air system was an example for an enclosure $20 \times 20 \times 20$ ft high. The air compressor housing was estimated in the same way using a floor space of $80 \mathrm{ft}^{2}$; however, the insulation would not be needed and a separate concrete pad would be used. The drum dollies would facilitate movement of the drums and have a capacity of 800 to $14001 \mathrm{~b}$. The digital low-ramp scale allows the drum plus dolly to easily be rolled onto the scale, and its capacity is $2000 \mathrm{lb}$. The warehouse platform scale had a capacity of $4000 \mathrm{lb}$ 
and a 4- $x$ 3-ft platform. A ramp would have to be fabricated separately or the drums hoisted onto the platform. Generous allowances were made for shipping and other overheads.

The estimates for new fans were supplied by a major vendor. These estimates included variable inlet vanes (vortex dampers) and belt or direct drives. These fans would be mounted externally to the existing filter house permitting some maintenance and inspection without breaking the vacuum seal of the housing. The estimate to upgrade the existing fan to its maximum 13 in. WG suction capacity was based on specifications furnished by the manufacturer; estimates for the motor, vortex damper, and drive were obtained locally. An example of installing a new larger vacuum capacity fan of the same configuration (double width, double inlet) in the existing housing was given as item 18 . If it were desirable to build a larger separate fan housing for a double-width doubleinlet fan, a cost estimate is provided as item 19. The construction of this housing would be with a 12-gauge inner wall, angle iron bracing, and 18-gauge outer wall. For this study, we recommend using the new single-width, singleinlet fan outside the filter house for capacities over 13 in. Wra. For a capacity between 11 and $13 \mathrm{in.} W G$, the upgrade for the existing fan was used as the cost estimate. For capacities below $11 \mathrm{in}$. WG, it was assumed that the existing fan would be used and vortex dampers and flow controls added so the fan would continue to operate at $11 \mathrm{in.} W(a$.

Two types of flow rate controls were estimated, motor speed control and vortex damper control (items 20 through 23, and 30). The motor speed controls use a velocity transducer and solid state motor speed control in a feedback control loop. Manual speed/flow setting was also included. The other system uses an averaging pitot tube and electronic pressure transducer, controller, and motor to drive vortex dampers. The transducer, controller, and dampers were included in the estimate to allow the upgrading of the existing fan. This estimate was used for this study; however, the motor speed control would allow easy reduction of airflow for special conditions such as maintaining a low airflow while cleaning shock attenuators, changing filter media, or other maintenance. 
The installation and ductwork estimate included several tasks: shop fabrication of ducts from the shock attenuators to the new filter device and to the existing filter house, a new outlet duct/stack from the existing filter house, labor to install and paint ducts and supports, labor to set new device in place, crane time, and labor to move the existing filter house to a new pad. Eighty man-hours each were budgeted for relocating the filter house and erecting the new device. Some new devices would require additional erection time. This was estimated by the vendors and added to the individual estimates as appropriate.

The leak test estimate included 32 man-hr of labor and the fabrication of plugs to seal the system. The electrical service estimate allowed for disconnecting the existing fan, reconnecting to the new fan and new controls. The example freight estimate assumed the use of a flat bed trailer. The individual cost estimates were used as explained in the appropriate appendix covering each filtration device. The cost estimates were current as of November 1983.

\section{REFERENCE}

Mossman, M. J., (ed). 1982. Mechanical and Electrical Cost Data. 1983. 6th Edition, Robert Snow Means Company, Inc., Kingston, Massachusetts. 
APPENDIX L

COST ANALYSIS SUMMARY METHOO 
APPENDIX L

\section{COST ANALYSIS SUMMARY METHOD}

The cost analysis summary table discussed in the main report (pp. 24-29) was derived from the data tabulated in Appendices $B$ through $\mathrm{J}$ and from the FILTER outputs described in Appendices $B$ and $C$. In most cases, the values shown in the report did not come directly from the other tabulations, but had to be derived from their data because of the different formats of the tables. This appendix describes the derivation of the summary values for the configurations recommended for each type of air cleaning device. Table L.1 shows how the labor, disposal volume, and replacement filter costs were calculated separately for the disposable filters of the type used in the existing filter banks that may be used downstream of any new device. FILTER lumped all these costs into a single output value, but they must be broken out to develop the summary table. The first part of the table shows the number of man-hours, compacted filter volume, and new filter cost associated with the change of a filter bank. The second part of the table shows the calculations for each device in their recommended configurations. The first three columns of data are the number of times each filter bank would be changed during exposure to 6000 shots with $4900 \mathrm{~g}$ of aerosol generated per shot, as estimated by FILTER. The manhours, filter cost, and compacted volume for each bank were multiplied by the number of respective bank changes. The estimated quantity of dust collected from each shot was also listed. Calculated values could be scaled to allow for changes in the assumptions characterizing the shots. The total cost of using disposable filters was calculated as a check against FILTER. A disposal cost of $\$ 24.26 / \mathrm{ft}^{3}$ (the value used in FILTER) was assumed for the check; however, $\$ 25 / \mathrm{ft}^{3}$ was used for the rest of the cost estimates described below.

The first two columns of Table L.2 list the recommended configuration for each device. The next two columns list the initial investment and the overall system filtration efficiency of each system (rounded to nine digits, values of one are not real). The labor for changing the disposable filters was taken 
TABLE L.1. Breakdown of Disposable Filter Usage Costs

Device
Electrostatic Baghouse
Baghouse, Pulse-jet, Std. Felt
Baghouse, Pulse-jet, Coated Bag
Baghouse, Shaker, Std. Sateen
Cartridge, Standard
Cartridge, Coated Medla
Cleanable High-Efficiency
Filter, 1-stage
Cleanable High-Efficiency
Filter, 2-stage
Vaned Inertial and Pulsed-Panel
Electrostatic Precipitatior
Pulsed-Panel
Existing System
Convent tonal Rolling Filter
Extended Surface at Bank 2
Peeled-Roll Filter
Single Cyclone

\begin{tabular}{|c|c|c|c|c|c|c|c|c|c|}
\hline Fuller Chan & Iges per & $\frac{6000 \text { shots }}{\text { Bank ? }}$ & $\begin{array}{c}\text { Changeout } \\
\text { Labor, } \\
\text { man-hr }\end{array}$ & $\begin{array}{l}\text { New } \\
\text { Med la, } \\
\mathbf{5}\end{array}$ & $\begin{array}{c}\text { Hedia } \\
\text { Disposal, } \\
\mathrm{ft}^{3} \\
\end{array}$ & $\begin{array}{c}\text { Olsposal } \\
\text { Labor, } \\
\text { man-hr }\end{array}$ & $\begin{array}{c}\text { Dust } \\
\text { Collected } \\
\text { by Cleanable } \\
\text { Device } \\
\text { / shot, } 9 \\
\end{array}$ & $\begin{array}{l}\text { Dust Per } \\
\text { Shot } \\
\text { Scaled,g }\end{array}$ & $\begin{array}{c}\text { Total, } \\
\text { \$K }\end{array}$ \\
\hline $\begin{array}{l}0.00 \\
0.00 \\
0.00 \\
0.00 \\
0.00 \\
0.00 \\
0.00\end{array}$ & $\begin{array}{r}4.90 \\
25.83 \\
1.36 \\
0.49 \\
37.23 \\
0.44 \\
1.75\end{array}$ & $\begin{array}{l}0.98 \\
0.06 \\
0.01 \\
0.00 \\
7.33 \\
0.08 \\
0.33\end{array}$ & $\begin{array}{r}25.41 \\
52.70 \\
2.80 \\
1.05 \\
191.71 \\
2.08 \\
8.80\end{array}$ & $\begin{array}{r}10981 \\
42046 \\
2222 \\
813 \\
83180 \\
947 \\
3875\end{array}$ & $\begin{array}{r}64.81 \\
219.76 \\
11.63 \\
4.27 \\
490.41 \\
5.52 \\
22.76\end{array}$ & $\begin{array}{r}12.73 \\
51.85 \\
2.74 \\
1.00 \\
96.45 \\
1.10 \\
4.50\end{array}$ & $\begin{array}{l}4900 \\
4900 \\
4900 \\
4900 \\
4900 \\
4900 \\
4900\end{array}$ & $\begin{array}{l}4900 \\
4900 \\
4900 \\
4900 \\
4900 \\
4900 \\
4900\end{array}$ & $\begin{array}{r}14 \\
51 \\
3 \\
1 \\
104 \\
1 \\
5\end{array}$ \\
\hline 0.00 & 0.00 & 2.08 & 33.31 & 6496 & 49.97 & 6.25 & 4900 & 4900 & 9 \\
\hline $\begin{array}{r}0.00 \\
9.00 \\
0.00 \\
1641.60 \\
401.09 \\
1641.60 \\
0.00 \\
92.40\end{array}$ & $\begin{array}{r}83.02 \\
25.60 \\
102.27 \\
1720.20 \\
1683.96 \\
755.651 \\
1252.02 \\
1496.63\end{array}$ & $\begin{array}{r}12.34 \\
3.11 \\
14.81 \\
192.85 \\
192.71 \\
495.79 \\
187.42 \\
189.83\end{array}$ & $\begin{array}{r}363.43 \\
100.91 \\
441.48 \\
9809.14 \\
7254.62 \\
14238.39 \\
5502.74 \\
6215.42\end{array}$ & $\begin{array}{r}172988 \\
51169 \\
211878 \\
3631364 \\
3388860 \\
3639634 \\
2613016 \\
3030501\end{array}$ & $\begin{array}{r}997.46 \\
290.85 \\
1219.37 \\
20920.37 \\
19282.85 \\
33063.67 \\
15075.10 \\
17298.62\end{array}$ & $\begin{array}{r}203.06 \\
60.52 \\
246.96 \\
5660.54 \\
4347.36 \\
4640.25 \\
3066.29 \\
3655.17\end{array}$ & $\begin{array}{r}4747 \\
4854 \\
4713 \\
0 \\
0 \\
0 \\
0 \\
2098\end{array}$ & $\begin{array}{r}4747 \\
4854 \\
4713 \\
0 \\
0 \\
0 \\
0 \\
2096\end{array}$ & $\begin{array}{r}215 \\
63 \\
263 \\
4618 \\
4216 \\
5027 \\
3244 \\
3756\end{array}$ \\
\hline
\end{tabular}


TABLE L.2. Breakdown of Initial Investment and Maintenance Costs

Device. Electrostatic Baghouse Baghouse. Pulse-jet, Std. Felt gaghouse, Shaker std. Sate Cartridge, standard Cartridge, Coated Medi Cleanable High-Efficiency

Filter. l-stage
Cleanable High-Efficiency Filter, 2-staye Vaned lnertial and Pulsed Panel Electrostat ic Precipitator Pulsed-P ane 16

Convent ional Rolling filter Extended Surfoce at Bant? Peeled-Roil Filter Bank 2 single Cyclone
Initial
Investinent.

2,3
2,3
2,3
2,3
2,3
2,3
2,3

2,3
2,3
2,3
$1,2,3$
$1,2,3$
$1,2,3$
2,3
$1,2,3$

167

167 Efficiency, 0.99999937 0.99999998 0.99499999 0.999995 0.999959 0.9999998

0.99999937

0.999993 0.9999984

0.999

(1)

0.99989

0.9975

0.99989 tabor, man-hr Teanable D1sposabie Repairs Operation Total Labor. Lan-hor. Cost 550
1320 1320 1056 2880
165
165
66 24

24

180

120

934

72

$\begin{array}{rr}25 & 548 \\ 53 & 548 \\ 3 & 549 \\ 1 & 324 \\ 192 & 548 \\ 2 & 548 \\ 9 & 444 \\ 33 & 3413 \\ 33 & \\ 363 & 548 \\ 101 & 487 \\ 441 & 548 \\ 9809 & 320 \\ 7255 & 324 \\ 4238 & 320 \\ 5503 & 320 \\ 6215 & 320\end{array}$

3823
282
282
2987
2827
282
3365
4241
3067
2839
2987
191
207
1912
2152
1912

$\begin{array}{ll}3823 & 4946 \\ 2827 & 4748\end{array}$

4748
4434

4434
6192

6192
3732
3542 4638

Labor ax Total Total $\begin{array}{lll}53.34 & 3.25 & 156.59 \\ 147.18 & 7.72 & 154.90\end{array}$ $\begin{array}{lll}157.18 & 7.72 & 154.90 \\ 137.45 & 7.72 & 145.17\end{array}$ $\begin{array}{lll}191.95 & 0.50 & 192.45\end{array}$ $\begin{array}{lll}115.68 & 7.72 & 123.41 \\ 109.80 & 7.72 & 11.53\end{array}$ $\begin{array}{lll}120.40 & 3.32 & 123.71\end{array}$ $\begin{array}{lll}143.79 \quad 2.00 & 115.74\end{array}$ $128.91 \quad 2.22$ $106.23 \quad 0.80 \quad 131.13$ $\begin{array}{lll}125.99 & 1.89 & 128.87\end{array}$ $\begin{array}{lll}373.28 & 373.28 \\ 328.12 & 0.50 & 328.62\end{array}$ 328.62
510.58 $\begin{array}{lll}249.45 & 0.50 & 249.95\end{array}$ 261.87 
from Table L.1. The labor for changing the cleanable filter media and for operating the system was taken from the tabulations in Appendices $B$ through $\mathrm{J}$. The labor and parts costs for performing various repairs were calculated using the methods outlined in the main report ( $p .18-22$ ), and assuming $\$ 31 /$ man-hr. The table shows the total number of man-hours and its associated cost and the total 20-year maintenance cost for each system.

Table L.3 shows the calculation of power, replacement filter media, and waste disposal costs for each candidate system. The power cost, from the tabulations in Appendices B through $\mathrm{J}$, was divided by $\$ 0.04 / \mathrm{kWh}$ to estimate the megawatt hours that would be consumed in 20 years. The disposable media costs were from Table L.I and the cleanable media replacement costs from the tabulations in Appendices $B$ through $\mathrm{J}$. The total cost for filter media replacement was then calculated. The labor required to dispose the cleanable media was calculated as suggested in Equation (2). The labor required to dispose of the disposable filters was taken from Table L.I. The labor to dispose of the dust collected from the hoppers into drums was calculated as suggested by Equation (4). The labor hours were summed and multiplied by $\$ 31 /$ man-hr to calculate the labor cost. The compacted volume of cleanable filter media was taken from the estimates of Appendices $B$ through $J$ and the volume of disposable filters from Table L.1. The amount of dust collected per shot, from Table L.l, was multiplied by 6000 shots and divided by $3 \times 10^{5} \mathrm{~g}$ per drum to estinate the number of drums the dust would fill; this in turn, was multiplied by $7.35 \mathrm{ft}^{3}$, the volume of a $55-g a l$ drum. The volume of compacted filters and dust was summed and multiplied by $\$ 25 / \mathrm{ft}^{3}$ to estimate the disposal cost without labor. The sum of the disposal cost and labor cost equals the total waste disposal cost. Tables L.1 to L.3 served as the basis for the summary table on pp. 27-29 of the main report. These cost estimates were compared against those generated in Appendices $B$ through $J$ and any differences were reconciled. The on $i y$ remaining difference occurred because a disposal cost of $\$ 24.26 / \mathrm{ft}^{3}$ was used in FILTER and $\$ 25 / \mathrm{ft}^{3}$ was used in this Appendix and elsewhere. This resulted in only a small difference (less than 1\%) in those systems where the usage of disposable filters was very high, so cost ranking was unaffected. 
TABLE L.3. Breakdown of Power, Replacement Media, and Waste Disposal Costs

\begin{tabular}{|c|c|c|c|c|c|c|c|c|c|c|c|c|c|c|c|}
\hline \multirow[b]{2}{*}{ Device } & \multirow{2}{*}{\multicolumn{2}{|c|}{${ }^{2} \bar{x}^{\text {Poner }}$}} & \multirow{2}{*}{\multicolumn{3}{|c|}{ Tea Media, $\frac{\mathrm{sk}}{\mathrm{K}}$}} & \multicolumn{3}{|c|}{$n+h r$} & \multirow{2}{*}{$\begin{array}{l}\text { Total, } \\
\text { man-hr }\end{array}$} & \multirow[b]{2}{*}{$\begin{array}{l}\text { Labor } \\
\text { cost. \$K }\end{array}$} & \multicolumn{3}{|c|}{ Yolune, $\mathrm{ft}^{3}$} & \multirow{2}{*}{$\begin{array}{l}\text { Monl abur } \\
\text { Disposal } \\
\text { Cost, \$K }\end{array}$} & \multirow{2}{*}{$\begin{array}{c}\text { Haste } \\
\text { Disposal } \\
\text { rotal. sk }\end{array}$} \\
\hline & & & & & & $\begin{array}{l}\text { Cleanable } \\
\text { Medid } \\
\end{array}$ & $\begin{array}{l}\text { Disposahle } \\
\text { Media } \\
\end{array}$ & Dust & & & $\begin{array}{l}\text { Cleanable } \\
\text { filters }\end{array}$ & $\begin{array}{l}\text { 0isposable } \\
\text { Filters }\end{array}$ & Dust & & \\
\hline Electrostatic Baçhouse & 160 & 4000 & 8.91 & 10.48 & 19.89 & 5 & 13 & 196 & 214 & 6.63 & 290 & 65 & 120 & 26.88 & 33.50 \\
\hline Baghouse, Pulse-Jet, Std. Felt & 160 & 4000 & 17.52 & 42.05 & 59.57 & 11 & 52 & 196 & 259 & 8.02 & 460 & 220 & 720 & 35.00 & 43.03 \\
\hline Baghouse, Pulse-Jet, Codted Bag & 160 & 4000 & 91.38 & 2.22 & 93.60 & 9 & 3 & 196 & 208 & 6.44 & 368 & 12 & 720 & 27.50 & 33.94 \\
\hline Raghouse, Shaker, std, Sateen & 118 & 2950 & 47.86 & 0.81 & 48.67 & 24 & 1 & 196 & 221 & 6.05 & 522 & 4 & 720 & 31.16 & 38.02 \\
\hline Cartridge, Standard & 139 & 3475 & 38.61 & 83.16 & 121.79 & 55 & 96 & 196 & 347 & 10.77 & 317 & 490 & 720 & 38.19 & 48.96 \\
\hline rartridge, Coated Media & 139 & 3475 & 38.61 & 0.95 & 39.56 & 55 & 1 & 196 & 252 & 7.82 & 317 & 6 & 720 & 26.07 & 33.89 \\
\hline Cleandble II gh-Efftclency & 230 & 5750 & 10.2 & 3.87 & 14.07 & 3 & 5 & 196 & 204 & 6.31 & 6 & 23 & 720 & 19.73 & 25.04 \\
\hline $\begin{array}{l}\text { Cleanable Hish-Ef fictency } \\
\text { Filter, 2-stage }\end{array}$ & 154 & $385 \mathrm{v}$ & 8.4 & 6.50 & 14.90 & 3 & 6 & 196 & 205 & 6.36 & 6 & 50 & 720 & 19.41 & 25.77 \\
\hline Vaned Inertial/Pulsed-9anel & $1 \mathrm{B1}$ & 4525 & $\$ 3.109$ & 172.99 & 51.17 & 47 & 203 & 190 & 440 & 13.64 & 112 & 497 & 698 & 45.18 & 58.82 \\
\hline Electrostatic Precipitator & 124 & 3100 & & 51.17 & 51.17 & & 61 & 194 & 255 & 1.90 & & 291 & 714 & 25.11 & 33.00 \\
\hline Pulsed-Panel 1 & 131 & 3275 & 36.94 & 211.88 & 248.82 & 40 & 249 & 189 & 477 & 14.80 & 96 & 1219 & 693 & 50.20 & 65.01 \\
\hline Existing System & 128 & 3200 & & 3631.36 & 3631.36 & & 5661 & 0 & 5661 & 175.48 & & 20920 & 0 & 523.011 & 698.49 \\
\hline Conventiond Rolling filter & IIB & 2950 & 93.4 & 3388.86 & 3482.26 & 467 & 4347 & 0 & 4814 & 149.25 & 350 & $192 \mathrm{B3}$ & 0 & 490.82 & $640.0 \mathrm{~J}$ \\
\hline Extended Surface at Bank 2 & 108 & 2700 & & 3639.63 & 3639.63 & & 4640 & 0 & 4540 & 143.85 & & 33064 & 0 & 826.59 & 970.44 \\
\hline Peeled-Roll \&llter & 193 & 6575 & 36 & 2613.02 & 2649.02 & 72 & 3066 & $\mathbf{0}$ & 3139 & 97.29 & 270 & 15075 & 0 & 383.63 & 480.91 \\
\hline Single Cyclone & 263 & 6575 & & 3030.50 & 3030.50 & & 3655 & 84 & 3739 & 115.91 & & 17299 & 308 & 440.18 & 556.09 \\
\hline
\end{tabular}




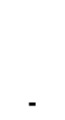




\section{DISTRIBUTION}

No. of

Copies

OFFSITE

10 Director

Ballistics Research Lab

AMXBR-TBD

Attention: Lou Herr

Aberdeen Proving Ground, MD 21005

Director

Ballistics Research Lab

AMXBR-TBD

Attention: Dr. William Gillich

Aberdeen Proving Ground, MD 21005

Director

Ballistics Research Lab

AMXBR-TBD

Attention: Dr. Fred Grace

Aberdeen Proving Ground, MD 21005

Director

Ballistics Research Lab

AMXBR-TBD

Attention: Dr. C. Wesley Kitchens

Aberdeen Proving Ground, MD 21005

Director

Ballistics Research Lab

AMXBR-TBD

Attention: Dr. Joseph Griffith

Aberdeen Proving Ground, MD 21005
No. of

Copies

4 Commander

Combat Systems Test Activity.

Attention: STECS-AA-A, Ken Ruff Aberdeen Proving Ground, MD 21005-5059

30 DOE Technical Information Center

\section{ONSITE}

\section{Kaiser Engineers}

L. H. Smith

DOE Richland Operations office

H. E. Ransom

27 Pacific Northwest Laboratory

R. K. Hadlock

N. S. Laulainen

J. V. Ramsdell

J. A. G1 issmeyer (10)

J. A. Bamberger

0. M. Lyso

W. B. Jackson

D. W. Dragnich

P. C. Hays

J. L. Downs-Berg

J. Mishima

Publishing Coordination (2)

Technical Information (5) 


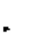

